\title{
PLAN DECENAL DE CULTURA 2016-2026 DEL DEPARTAMENTO DE CUNDINAMARCA
}

CONVENIO DE ASOCIACIÓN 226 DE 2015 ENTRE EL IDECUT Y LA UNIVERSIDAD SERGIO ARBOLEDA

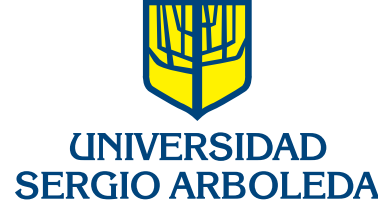

Acreditación Institucional

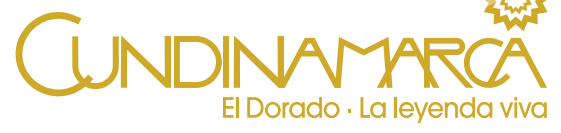

Bogotá, Colombia 2015 
Plan decenal de cultura 2016 - 2026 del departamento de Cundinamarca /Miguel Antonio Geballos Arévalo ... [et al.]. - Bogotá: Universidad Sergio Arboleda, 2015.

$142 \mathrm{p}$.

ISBN 978-958-8866-91-8

1. POLITICA CULTURAL - CUNDIMARCA - 2016 - 2026 2. PLANIFICACIÓN CULTURAL - GUNDINAMARCA I. Ceballos Arévalo, Miguel Antonio

306.08968861 ed.21

\section{PLAN DEGENAL DE CULTURA 2016-2026 DEL \\ DEPARTAMENTO DE GUNDINAMARGA}

Convenio de asociación 226 de 2015 entre el IDECUT y la

Universidad Sergio Arboleda

ISBN: 978-958-8866-91-8 Rustica

ISBN: 978-958-8866-92-5 Digital

(C) Miguel Antonio Ceballos Arévalo

(C) Antonio Quiñones Valero

(C) Santiago José Castro Agudelo

(C) Viviana Manrique Zuluaga

(C) Rodrigo González Quintero

Edición: diciembre de 2015

Prohibida la reproducción o cita impresa o electrónica total o parcial de esta obra, sin autorización expresa y por escrito de la Universidad Sergio Arboleda y del Instituto de Cultura y Turismo de Cundinamarca. Las opiniones expresadas en esta obra son responsabilidad de los autores.

Calle 74 No. 14-14

Teléfono: (571) 3257500 ext. 2131/2260

www.usergioarboleda.edu.co

Bogotá, D.C.

Directora de Publicaciones Científicas:

Yadira Caballero Quintero

yadira.caballero@usa.edu.co

Director del Fondo de Publicaciones:

Jaime Arturo Barahona Caicedo

jaime.barahona@usa.edu.co

Diseño y diagramación: Maruja Esther Flórez Jiménez

Diseño carátula: Jimmy Salcedo Sánchez

Imagen de portada: Shutterstock 109766645

Con la Imagen seleccionada de como portada, los autores

quieren mostrar que la construcción de las políticas públicas

de la cultura, en el Departamento de Cundinamarca, fue un

proceso colectivo y participativo en el cual confluyeron una serie

de intereses y dinámicas tanto sectoriales como territoriales.

Impresión: Digiprint

Bogotá, D.C. 


\section{PLAN DECENAL DE CULTURA 2016-2026 DEL DEPARTAMENTO DE CUNDINAMARCA}

CONVENIO DE ASOCIACIÓN 226 DE 2015

ENTRE EL IDECUT Y LA UNIVERSIDAD SERGIO ARBOLEDA

Miguel Antonio Ceballos Arévalo

Antonio Quiñones Valero

Santiago José Castro Agudelo

Viviana Manrique Zuluaga

Rodrigo González Quintero
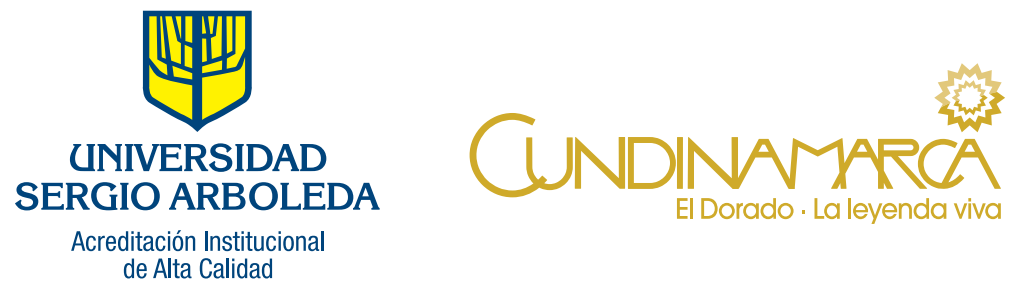

de Alta Calidad

Bogotá, Colombia 2015 


\section{AUTORIDADES INSTITUCIONALES}

Instituto de Cultura y Turismo de Cundinamarca - IDECUT

Guillermo Rivera Flórez Gobernador (e) de Cundinamarca Juan Ramón Jiménez Osorio Gerente IDECUT

Ana María Boada Ayala Subgerente de Cultura IDECUT

William Humberto Ardila Subgerente Administrativo IDECUT

Sandra Hoyos Acosta Subgerente de Turismo IDECUT

María Alejandra Vallejo Castro Asesora de Patrimonio

\section{UNIVERSIDAD SERGIO ARBOLEDA}

Rodrigo Noguera Calderón Rector Magnifico

Germán Quintero Andrade Vicerrector Académico

José María del Castillo Abella

Vicerrector de Gestión Académica

Jorge Noguera Calderón

Vicerrector Administrativo

Miguel Antonio Ceballos Arévalo

Decano Escuela de Política

y Relaciones Internacionales
UNIVERSIDAD SERGIO ARBOLEDA

ACREDITACIÓN DE ALTA GALIDAD

OTORGADA POR EL MINISTERIO

DE EDUCACIÓN NACIONAL, RESOLUCIÓN 590 DE 2015.

\section{GRUPO DE INVESTIGACIÓN} DE ANÁLISIS POLÍTICO,

CATEGORÍA A DE COLCIENCIAS, RESOLUCIÓN 5 DE 2015.

Equipo de Investigación

Miguel Antonio Ceballos Arévalo, $\mathrm{PhD}$ (c) Antonio Quiñones Valero, $\mathrm{PhD}(\mathrm{c})$ Investigadores Principales

Santiago José Castro Agudelo, MSc

Viviana Manrique Zuluaga, MSc

Rodrigo González Quintero, $\mathrm{PhD}$ Co Investigadores

Clara Inés Sánchez Arciniegas, $\mathrm{PhD}$ (c) Asesora

Álvaro Andrés Alfonso González Asistente de Investigación

José Miguel Avelino Pinilla Cindy Lorena Roa Ovalle

Procesamiento de información

Yadira Caballero Quintero

Edición y análisis de información

María Emilia Aponte Mantilla Alejandro Cuervo Bojacá Corrección de estilo

Maruja Esther Flórez Jiménez Diagramación 


\section{AGRADECIMIENTOS}

Los autores agradecen de manera especial a Dr. Juan Ramón Jiménez Osorio por la iniciativa y el acompañamiento en la ejecución del proyecto. Así mismo, a la Dra. Ana María Boada Ayala, quien constantemente retroalimentó el proceso y es artífice del resultado. También los autores agradecen a los funcionarios del IDECUT, especialmente a María Alejandra Vallejo Castro, Ricardo Hernández Sandoval y a Edna Yamile Calvache Padilla por la disposición y colaboración constantes. Finalmente, se agradece a todas las personas que participaron y contribuyeron en la formulación del Plan Decenal. 



\section{CONTENIDO}

PRÓLOGO................................................................... 15

INTRODUGGIÓN........................................................ 17

\section{Capítulo 1}

MARGO GONGEPTUAL ................................................ 21

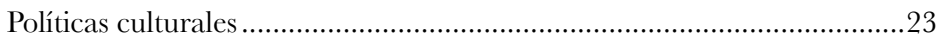

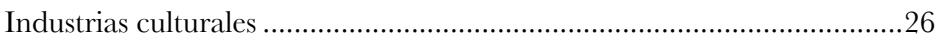

\section{Capítulo 2}

\section{POLITIGAS GULTURALES DESDE EL GONTEXTO}

INTERNAGIONAL ................................................... 29

Principales directrices y lineamientos internacionales sobre cultura ........29

Referentes internacionales de políticas culturales ...................................32

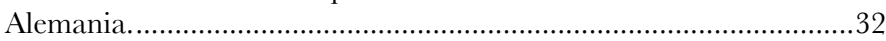

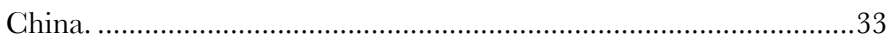

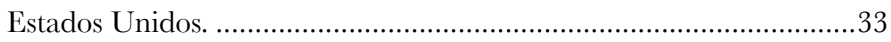

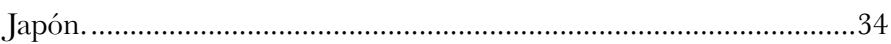

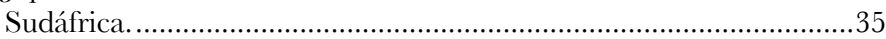

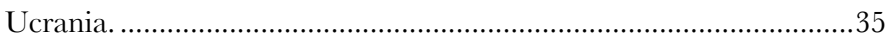

Variables frecuentes en los países referentes. .......................................36

\section{Capítulo 3}

GONTEXTO DE LA GULTURA EN GOLOMBIA............ 39

Antecedentes de políticas culturales en Latinoamérica y Colombia.......................39

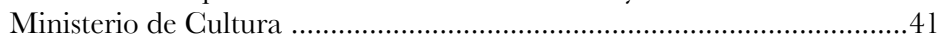

Marco jurídico de la cultura en Colombia..............................................45

Normas relacionadas con la cultura. ................................................... 45

Documentos de política económica y social relacionados con la

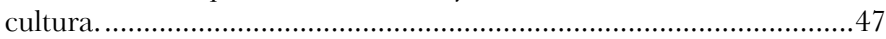

Análisis de la regulación de la cultura en Colombia.................................48

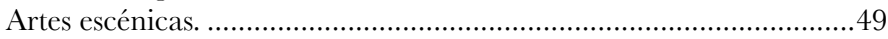

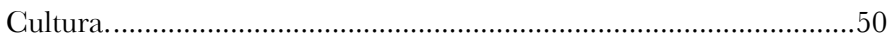

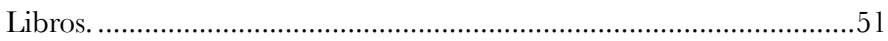

Obras cinematográficas. ..................................................................52

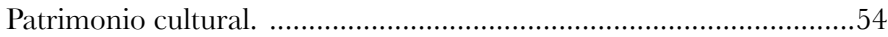

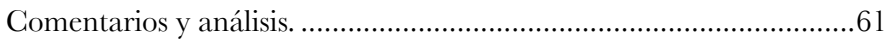

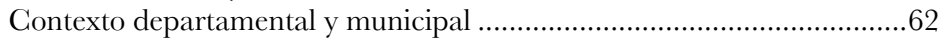

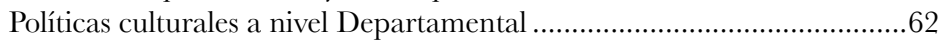

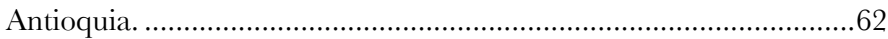

Ejes temáticos de la política pública. ..................................................63 


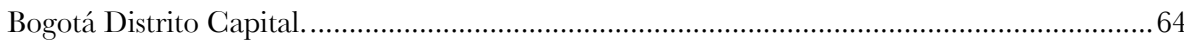

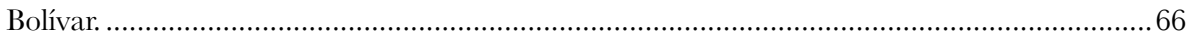

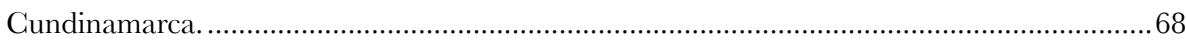

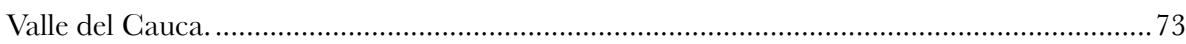

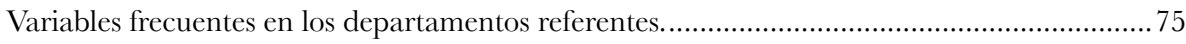

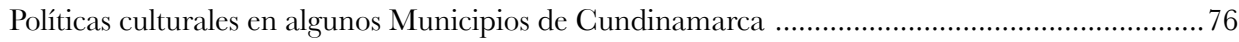

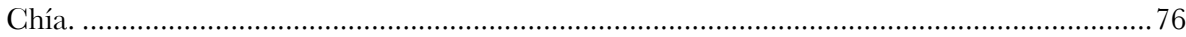

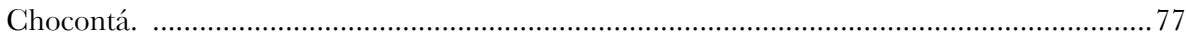

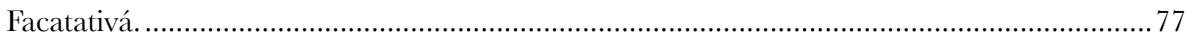

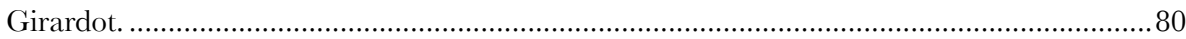

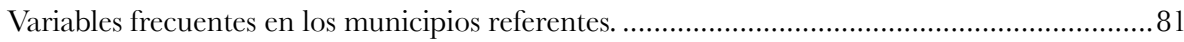

\section{Capítulo 4}

RESULTADOS DEL PROGESO DE INVESTIGAGIÓN...................................... 83

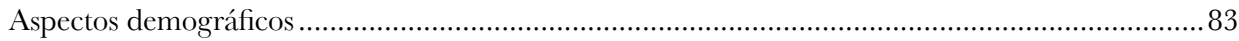

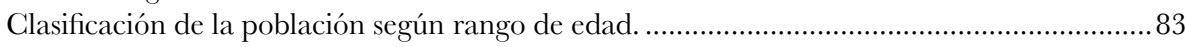

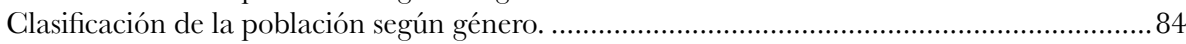

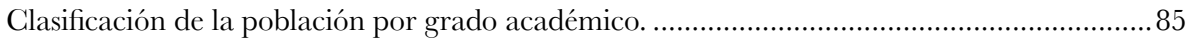

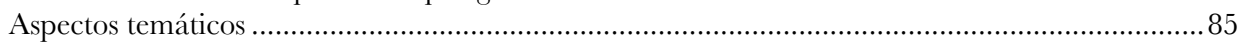

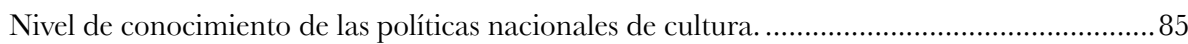

Nivel de consideración de reestructuración de las políticas de cultura nacionales.....................86

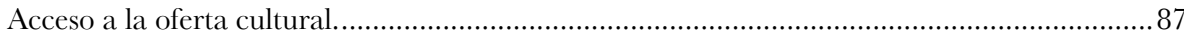

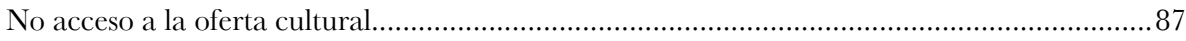

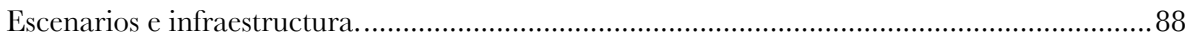

Apoyo e impulso a Bandas, bibliotecas, música, danza, teatro, patrimonio y eventos

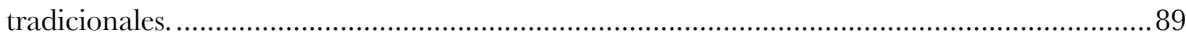

Identificación de situaciones consideradas problemáticas como insumo para el plan decenal

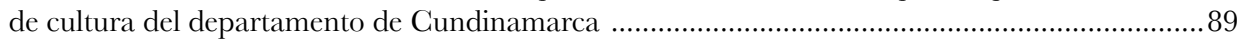

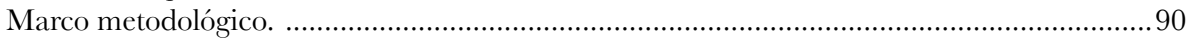

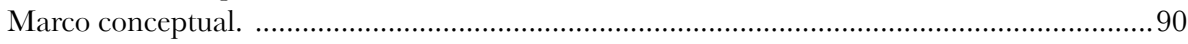

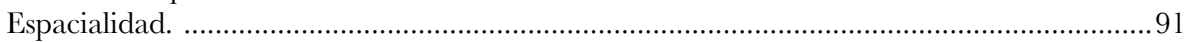

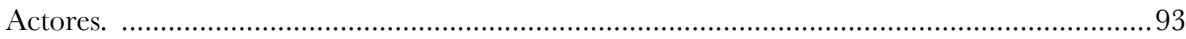

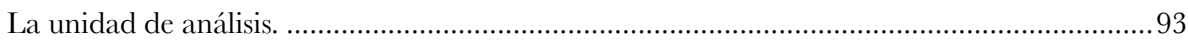

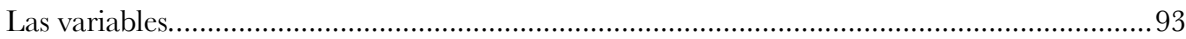

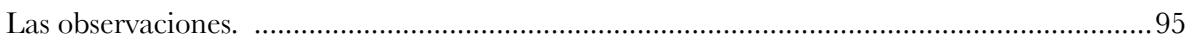

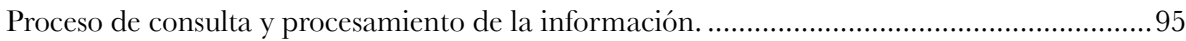

El uso de la matriz de Vester para el procesamiento de la información.....................................95

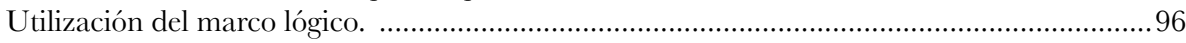

Utilización de software para el procesamiento de la información............................................97

Caracterización de los asuntos considerados problemáticos como insumo para la política

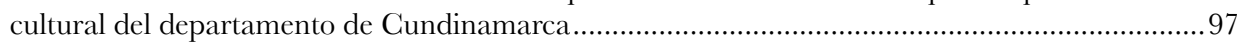

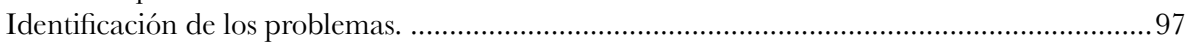

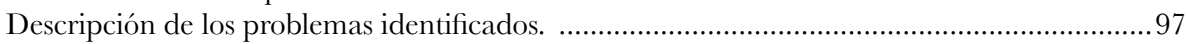

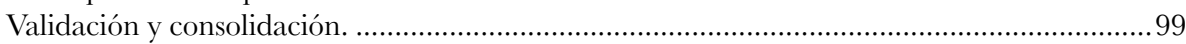

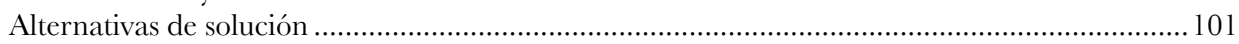

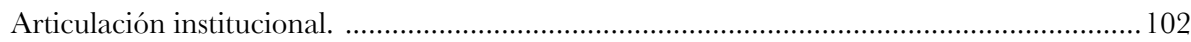

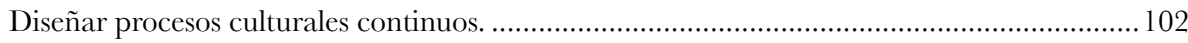

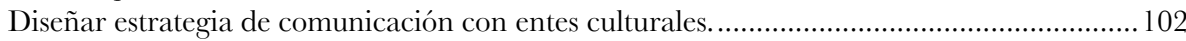




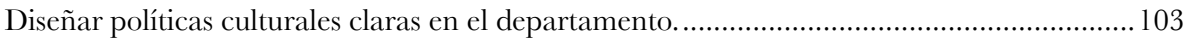

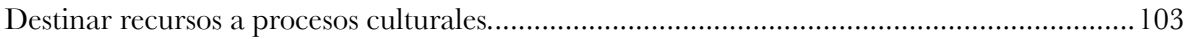

Impulsar una cátedra ciudadana para impulsar conocimientos culturales. ............................ 104

Impulsar una estrategia de empoderamiento ciudadano por el patrimonio cultural.............. 104

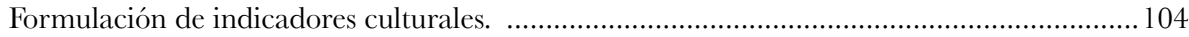

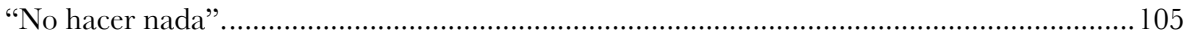

\section{Capítulo 5}

\section{PLAN DEGENAL DE GULTURA 2016-2026 DEL DEPARTAMENTO}

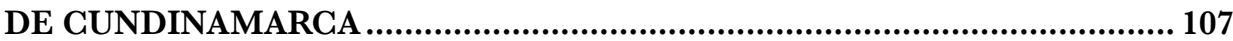

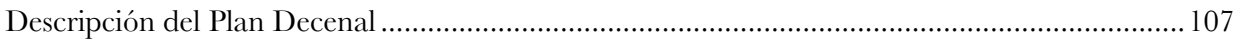

Metaproblema 1: Baja continuidad en los procesos de gestión y ejecución de programas

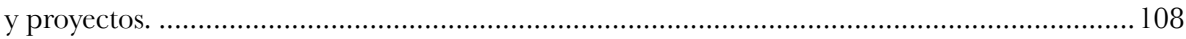

Metaproblema 2: Bajos recursos, fuentes y canalización de financiación. ............................... 109

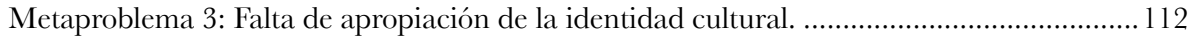

Metaproblema 4: Falta de infraestructura adecuada y suficiente. .......................................... 114

Metaproblema 5: Baja articulación tanto entre actores e instituciones del sistema

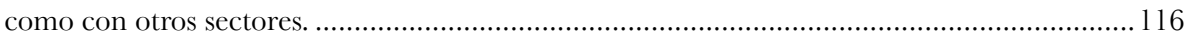

Metaproblema 6: Falta de gestión y de alcance institucional .................................................. 118

Metaproblema 7: Baja información, comunicación y divulgación tanto de la oferta

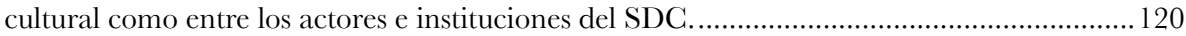

Metaproblema 8: Bajo nivel de formación y de generación de conocimiento (educación

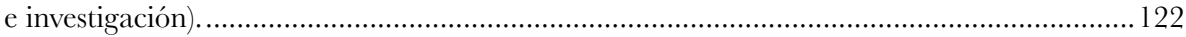

Metaproblema 9: Baja cobertura y acceso de la población a los programas y proyectos....... 124

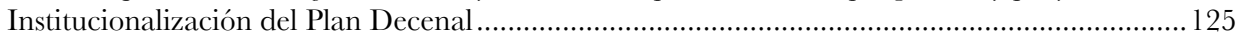

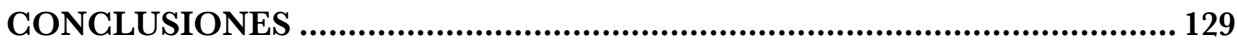





\section{TABLA DE ILUSTRAGIONES}

\section{Ilustración 1.}

Clasificación de la población con aplicación de instrumentos de medición por edad

Ilustración 2.

Clasificación de la población según género.

Ilustración 3.

Clasificación de la población por grado académico .85

Ilustración 4.

Conocimiento de políticas nacionales de cultura 86

Ilustración 5.

Porcentaje de actores que están de acuerdo a la reestructuración de las políticas culturales del país.

Ilustración 6 .

Razones de acceso a la oferta cultural.

Ilustración 7.

Razones de no acceso a la oferta cultural.

Ilustración 8.

Porcentaje de suficiencia y estado actual de los escenarios e

infraestructura cultural.

Ilustración 9 .

Calificación según la oferta cultural.

Ilustración 10.

División político administrativa del Departamento de Cundinamarca....92

Ilustración 11.

Valoración de los problemas identificados 100 



\section{ÍNDIGE DE TABLAS}

Tabla 1.

Fases de ejecución de actividades del proyecto ........................................ 19

Tabla 2.

Principales políticas culturales formuladas e implementadas por el

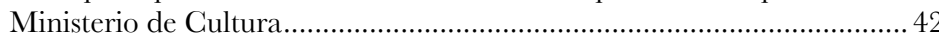

Tabla 3.

Listado de normas relacionadas con la cultura desde 1993 hasta 2013 ... 46

Tabla 4.

CONPES sobre cultura entre 2002 y 2014 48

Tabla 5 .

Identificación de provincias que corresponden a cada una de las zonas intersectoriales para el estudio de identificación de problemas de cultura 91

Tabla 6.

Porcentaje de validación por problema y clasificación del mismo 101 



\section{PRÓLOGO}

H l derecho a participar en la vida cultural se debe

Centender en el marco de los derechos culturales como parte del estatuto de los Derechos Humanos. El evento de la aprobación, en 1966, en las Naciones Unidas de los Pactos Internacionales de Derechos Civiles y Políticos y de Derechos Económicos, Sociales y Culturales ha favorecido al proceso de instrumentación normativa, dando lugar a una amplia dimensión de los derechos culturales.

A partir del año 2014, el Instituto Departamental de Cultura y Turismo de Cundinamarca -IDECUT- se propuso reactivar los consejos departamentales de artes escénicas, música, patrimonio, artes plásticas y danzas, con el fin de lograr en 2015 la consolidación del Plan Decenal de Cultura para el Departamento.

Con el claro objetivo de dar continuidad a los procesos que se emprendieron durante este gobierno, la formulación del Plan Decenal de Cultura busca dar origen a una política pública departamental que permita la transformación de los municipios mediante la valoración, preservación, recuperación y difusión del patrimonio cultural.

A través del Convenio de cooperación entre IDECUT y la Universidad Sergio Arboleda, cuyo alcance fue el diseño y formulación de la política pública de cultura para el departamento, se pretendió abordar este reto. La tarea consistió en construir un instrumento de planificación a corto, mediano y largo plazo, con las herramientas teóricas y metodológicas que la Escuela de Política y Relaciones Internacionales, de esta Universidad, tiene a su 
disposición. El objetivo principal fue tener una forma concreta de orientar las acciones de las entidades públicas departamentales, que permita la sostenibilidad y la continuidad del campo cultural en el Departamento.

Uno de los puntos axiales en este proceso fue la identificación de los problemas socialmente relevantes, así como la formulación de acciones y soluciones a los mismos.

Así, la formulación de este plan es producto de la construcción participativa, mediante mesas regionales transectoriales y la participación del Consejo Departamental de Cultura y de los funcionarios del IDECUT, en un trabajo a muchas manos, que pretende concretar unos lineamientos que buscan hacer cumplir el derecho de las personas a participar en la vida cultural, a gozar de los beneficios del progreso científico y de sus aplicaciones, y a beneficiarse de la protección de los intereses morales y materiales que le correspondan. Consideramos este Plan como parte del deber de adoptar, a fin de asegurar el pleno ejercicio de tales derechos, las medidas gubernamentales necesarias para la conservación, el desarrollo y la difusión de la ciencia y la cultura en el Departamento de Cundinamarca.

Poniendo de presente que el disfrute efectivo del derecho a la cultura no es posible si no se articula con el de otros derechos económicos y sociales, como derechos humanos indivisibles e interdependientes, entregamos con orgullo el resultado de un trabajo mancomunado que busca soluciones concretas a los problemas más apremiantes que tiene el sector cultural en nuestro departamento. Será deber tanto de la comunidad, como del gobierno entrante: conocerlo, divulgarlo y exigir su cumplimiento.

Juan Ramón Jiménez Osorio

Gerente IDEGUT

Bogotá, diciembre de 2015 


\section{INTRODUGGIÓN}

T a cultura, como medio y proceso de manifesta-

Lción, reconocimiento e identidad, atañe a la ciudadanía. En este sentido, es menester tomar acciones que aboguen por el mantenimiento y desarrollo de este sector. De esta manera, y entendiendo además, que la cultura está incardinada en el entramado de las relaciones con el Estado, la formulación de políticas públicas, como instrumentos de planeación, contribuirán al establecimiento de un "camino" a seguir tanto por los hacedores de la políticas (policymakers) como por todas las personas que de una manera u otra se ven relacionadas, beneficiadas o inclusive afectadas (externalidades) por la cultura en el departamento de Cundinamarca.

El Estado colombiano, por medio del Ministerio de Cultura, ha venido implementando y ejecutando una serie de acciones en pro de la cultura. En el texto titulado Compendio de Politicas Culturales (Ministerio de Cultura, 2011) y en el "Plan Nacional de Cultura 2001-2010. Hacia una ciudadania democrática cultural. Un plan colectivo desde y para un país cultural" (Ministerio de Cultura, 2001) se pueden observar y analizar algunas de estas acciones que desde lo público han venido fortaleciendo el sector. No obstante, y en tanto la heterogeneidad del Estado es prominente, es fundamental la gestión y puesta en marcha de políticas públicas, articuladas a las nacionales, pero que den cuenta de los diferenciales y las necesidades específicas de cada departamento. Es así, como el IDECUT en convenio con la Universidad Sergio Arboleda desarrollaron el proyecto para la formulación del Plan Decenal de Cultura 20152025 del Departamento de Cundinamarca. 
La formulación del plan decenal de cultura para el departamento de Cundinamarca se realizó por medio de una metodología participativa. Se buscó que por medio de la experiencia, experticia y conocimiento de los actores que se ven relacionados, se estableciera el camino o ruta a seguir en los próximos diez años. En este sentido, el Plan intentó reflejar los diferentes intereses y percepciones de los actores. Como insumo para la construcción, se apeló a la revisión tanto de los planes como políticas que en materia de cultura se han implementado y desarrollado a nivel nacional y local, como se puede observar en el capítulo quinto. Además, se tuvieron en cuenta los lineamientos que han emanado de instituciones internacionales. La transferencia de políticas públicas (policy transfer), como lo plantean Dumoulin y Saurugger (2010), entendidas como el mecanismo de circulación de ideas y modelos desde otros países o desde instituciones del orden internacional, han sido importantes en el proceso de formulación. Por ejemplo, en el proceso se tuvieron en cuenta los planteamientos y acuerdos de la UNESCO sobre cultura y su aplicación por medio de políticas públicas.

Este texto busca consolidar las bases conceptuales para la compresión de las políticas culturales en el Departamento de Cundinamarca, en el marco de la noción de cultura que orienta el desarrollo de este sector. Se pretende realizar una descripción bibliográfica que analiza diferentes definiciones de cultura desde distintas disciplinas y marcos teóricos. El fin del presente documento resultado de investigación, es plantear el camino hacia la formulación de la política pública de la cultura en el Departamento de Cundinamarca. Se destaca el proceso de las políticas culturales en los ámbitos internacional, nacional y local. Adicionalmente, y no menos importante el consolidado del proceso desarrollado para la formulación del plan decenal, aplicación de instrumentos de medición, resultados del proceso, líneas de base, análisis y prospectiva de los problemas identificados, soluciones y estrategias para abarcar la cultura en el departamento de Cundinamarca. De manera anticipada, y como se podrá observar en los resultados del proceso, una de las necesidades más acentuadas es el fortalecimiento institucional; y, en esta medida, las alternativas de solución están dirigidas primordialmente a asuntos como el aumento de recursos disponibles, mejoramiento de infraestructura, articulación entre actores, gestión y alcance, mejoramiento de los canales de divulgación, etcétera'.

Ver: capítulo 5. "Plan Decenal". 
El desarrollo y ejecución del proyecto de investigación, como se puede ver en la Tabla 1, se adelantó en seis fases; de ellas se destacan los el momento prospectivo y así como el de ajuste y concertación, en tanto fue por medio de los actores involucrados en el sector que se pudieron establecer las situaciones consideradas como problemáticas y que requieren ser atendidas por la Gobernación de Gundinamarca. Con este tipo de intervenciones y de interpelaciones a los actores se busca encontrar e interpretar información de base sobre las principales problemáticas; por medio de dicho análisis se pretende resaltar la interpretación que cada actor de decisión da a una misma realidad. Teniendo en cuenta lo anterior, en el marco de las políticas públicas se usó el enfoque y método cualitativo interpretativo con revisión de fuentes tanto primarias como secundarias. La información cualitativa obtenida de la aplicación de los instrumentos de medición se procesó con el software AtlasTI.

\section{Tabla 1. Fases de ejecución de actividades del proyecto}

\section{FASES}

Preparación y diagnóstico previo

Validación y consolidación

Prospectiva

\section{AGTIVIDADES}

- Revisar el estado del arte de los procesos de planificación cultural en los distintos municipios.

- Identificación y documentación de casos exitosos

- Socialización y validación del diagnóstico garantizando la participación de agentes culturales del territorio

- Implementación de metodologías de prospectiva social que aseguren la participación de agentes culturales del territorio.

- Acciones de recolección, sistematización, consolidación y análisis de información generada a partir de ejercicios de participación comunitaria.

- Presentar los marcos conceptuales, metodológicos y de implementación de la política cultural, como parte de la estructura del plan.

- Análisis prospectivo del producto del diagnóstico

- Identificación de problemáticas y soluciones

- Talleres de planeación participativa con la comunidad 
Documento con las observaciones y recomendaciones al

Ajuste y Concertación plan, generadas por los espacios de participación y expertos que participen en el desarrollo del proyecto.

Socialización del plan con los actores del sector.

Institucionalización

Redacción de un proyecto de ordenanza y exposición de motivos.

\section{Fuente: Elaboración de los autores.}

El presente documento se estructura en cinco capítulos. En el primero de ellos, se realiza una aproximación conceptual a la cultura, planteando algunos asuntos como lo son la discusión entre mercado e industria cultural y la no mercantilización de la cultura. Además, se describen cómo han sido las políticas culturales en otras latitudes y se presentan algunos marcos y referentes. En segundo lugar, se plantea el contexto nacional del desarrollo de la política pública de cultura en Colombia en el marco del Sistema Nacional del ente rector. A continuación, se presenta un análisis y recopilación del marco jurídico desarrollado para el sector cultural. En el capítulo tercero, se recopilan algunos ejemplos de políticas públicas en el orden departamental y municipal. En el cuarto capítulo, se presentan los resultados de la aplicación de los instrumentos de medición aplicados a los actores. Además, se presentan los problemas identificados y las alternativas de solución propuestas. Finalmente, el quinto capítulo se presenta la estructura del Plan Decenal y la herramienta de institucionalización, con el fin que la Asamblea de Cundinamarca avale el Plan y se generen los instrumentos y herramientas para darle ejecución. 


\section{Capítulo 1}

\section{MARGO GONGEPTUAL}

Dara el desarrollo del presente documento se hace

1 indispensable plantear la cultura desde una visión histórica y holística a la vez, que permita establecer el proceso de evolución del concepto y de su trascendencia en la constitución de las estructuras sociales y desarrollo del ser humano a través de la historia.

Actualmente, cuando se revisa la literatura sobre cultura, el primer hallazgo es que existe un universo de referentes a cultura, a culturas, o a la cultura, o a lo cultural, o al culturalismo, o al multiculturalismo. Lo anterior, implica la existencia de diversas formas de interpretación, delimitaciones y enfoques sobre el ámbito cultural. Existen elementos de estudio, además de la historia, asociados la producción material, espiritual y simbólica de una colectividad humana. El estudio y el análisis de estos objetos sociales, han generado escuelas de pensamiento relacionadas con los métodos y metodologías de investigación en campo, que consideran la estructura social con vinculación a un territorio y a una temporalidad que genera memoria, hábitos y costumbres, por un lado; y, por otro, diversos tejidos de intereses comunes y compartidos, que se hacen más visibles en el contexto de la globalización que, como paradoja, conlleva, la localización.

Sin embargo, en aras de establecer un orden lógico, se recurre a referencias sobre los orígenes de la etimología de la palabra cultura, constitutivo del acervo cultural occi- 
dental. La cultura es inherente al ser humano. Según la UNESCO cultura es entendida como

[...] “...el conjunto de los rasgos distintivos, espirituales y materiales, intelectuales y afectivos que caracterizan una sociedad o un grupo social. Ella engloba, además de las artes y las letras, los modos de vida, los derechos fundamentales al ser humano, los sistemas de valores, las tradiciones y las creencias (UNESCO, Declaración de México sobre las políticas culturales, 1982).

Desde la antigüedad se ha asumido la cultura como la diversificación de costumbres o actividades que enriquecen la vida cotidiana del hombre. La historia se ha encargado en sí misma de fortalecer esa estrecha relación e inmanencia. Si hay que partir desde algún punto de la historia para hablar de cultura, es necesario remitirse a la etimología de la palabra, acuñada en la Grecia antigua. Pues, fueron los griegos "los primeros que pensaron en no perder su memoria histórica y cultural, y se propusieron avanzar en el teatro, la comedia, la poesía, la música, la arquitectura, y construyeron así un gran emporio cultural" (Retamoso, 2010).

El desarrollo histórico del concepto de cultura, su génesis desde los griegos hasta el entendimiento humanístico en el Siglo XX, siempre está asociado a lo más elevado del pensamiento y del espíritu humano. Investigaciones socio genéticas y psicogenéticas, escrita en 1939 y publicada por primera vez en 1969, del sociólogo alemán Norbert Elías, a partir de la diferenciación que establece entre "civilización" y "cultura", introduce claves del pensamiento contemporáneo sobre la noción de cultura. Elias plantea que si bien es cierto "que las sociedades que han acuñado las palabras "cultura" y "civilización" no son "sectas ni familias, sino pueblos enteros o, quizás solamente ciertos sectores de esos pueblos" (Elías, 2009, p. 58), o incluso más pequeños $y$, sobre este punto, refiere que independientemente de los grupos pequeños que hayan acuñado los términos, al formar parte del lenguaje de los seres humanos, hacen parte de una tradición que es común para explicar situaciones similares. Para Elías: "los conceptos matemáticos son explicables sin necesidad de remitirse a situaciones históricas; los conceptos de "civilización" y "cultura", no lo son". (Elías, 2009, p. 58).

La segunda mitad del siglo XX vio nacer la institucionalidad de la cultura, en cabeza de organismos internacionales como la UNESCO, que 
asentará la noción de patrimonio cultural, primero material, luego material y natural, y finalmente, la actual clasificación de patrimonio material e inmaterial. Conceptos como valoración, uso, desarrollo, conservación y salvaguardia, entrarán en el léxico de la cultura en tiempos posmodernos. Hoy, la cultura cuenta con todo tipo de intervenciones, apoyos, políticas, y atención. Desde que la UNESCO (2002) proclamara la Declaración Universal de la Diversidad Cultural, el entendimiento de la cultura amplío su horizonte, y el espectro de acción ha sido más claro.

\section{Políticas culturales}

Las políticas culturales no son un concepto unificado ni único sobre el que exista un consenso; circulan múltiples definiciones de política cultural; no obstante George Yudice y Toby Miller sostienen que la política cultural "se refiere a los apoyos institucionales que canalizan la creatividad estética y las formas de vida colectivas" y "está contenida en instrucciones de carácter regulatorio y sistemático" (Ministerio de Cultura, 2011). En este sentido, las políticas culturales hacen referencia al sumario de acciones y procesos que contribuyen al desarrollo de las mismas.

La intervención del Estado respecto a lo cultural se ha dado desde cuando el concepto de cultura se asociaba casi con exclusividad a las élites sociales e intelectuales y al conocimiento depurado que requería de espacios propios para su consulta "pública"; la creación de las grandes Bibliotecas y Museos Nacionales, son un claro ejemplo de esa intervención: grandes espacios, abiertos al público, pero mediados por las capacidades propias de las personas para poder acceder a ellos. Hoy el escenario es otro; se vive la masificación del acceso a la cultura mediado por la tecnología y la globalización. En estos contextos, el papel del Estado frente a las políticas culturales ha evolucionado, desde la cultura asumida como un deber propio del Estado como un imperativo ético a subsidiar y mantener, a la postura que nos lleva a vivir y a participar de la cultura como parte de toda una maquinaria rentable y como factor de productividad. En consecuencia, se ha venido hablando de cultura y de políticas culturales, desde los más variados tópicos y enfoques, acordes con cada época.

Por ejemplo, en España, el referente para señalar el inicio de la política cultural púbica, es la creación de la Biblioteca Nacional y de la Real 
Academia de la Lengua, ambas a comienzos del siglo XVIII; y en España, como en otros países europeos, mucho tiempo después (década delos 70), la intervención pública en cultura seguía centrándose en instituciones culturales de carácter clásico a las que pocos tenían acceso ya que el analfabetismo seguía siendo uno de los principales problemas a erradicar. Sin embargo, el Estado seguía siendo el principal agente cultural. Más aún, el papel del Estado a través de la política cultural podía ir en contra las tendencias más contemporáneas y rupturistas, desmontado cualquier tipo de apoyo a nuevas expresiones que salieran del estatus quo. Hoy, en cambio, el imperativo ético se basa y se fundamenta en la libertad de expresión y en la inclusión de la diversidad cultural, como imperativos éticos, cuya gestión se ha convertido, en sí misma, en otra política; el cómo generar los instrumentos idóneos para el logro de esos imperativos éticos.

Para algunos autores los elementos conceptuales esenciales para comprender las políticas culturales están contenidas en las siguientes definiciones:

García Canclini (1997) señala que el concepto de políticas culturales hace referencia al:

[...] conjunto de intervenciones realizadas por el Estado, las instituciones civiles y los grupos comunitarios organizados a fin de orientar el desarrollo simbólico, satisfacer las necesidades culturales de la población y obtener consenso para un tipo de orden o transformación social (p. 18).

Reafirma García Canclini (2001) al decir que:

Necesitamos actualizar las leyes y crear otras nuevas, porque las industrias culturales han pasado a ser predominantes en la formación de la esfera pública y la ciudadanía, como lugares de información, sensibilización a las cuestiones de interés común y deliberación entre sectores sociales. Desde el siglo XIX y hasta mediados del XX, estas funciones habían sido cumplidas por la literatura, las artes visuales y la música, que proporcionaron recursos para reflexionar sobre el origen de la nación, sobre el carácter distintivo de cada cultura y para elaborar los signos de identidad. Recordemos el significado del muralismo mexicano, de la literatura histórica o del «boom» en Argentina, Perú, Colombia, México y otros países. La radio y el cine contribuyeron a este proceso desde los años 40 y 50 , pero fue en las últimas tres décadas cuando las industrias culturales se volvieron protagonistas de los imaginarios sociales. Por eso, participar en el intercambio mediático es ahora decisivo para ejercer la ciudadanía (p. 22) 
Por su parte Coelho (1997) infiere que:

La política cultural constituye una ciencia de la organización de las estructuras culturales y generalmente es entendida como un programa de intervenciones realizadas por el Estado, instituciones civiles, entidades privadas o grupos comunitarios con el objetivo de satisfacer las necesidades culturales de la población y promover el desarrollo de sus representaciones simbólicas (p. 292).

Para Álvarez, Dagnino, \& Escobar (2001, págs. 25-26) "Interpretamos (2001) se interpreta la política cultural como:

[...] el proceso generado cuando diferentes conjuntos de actores políticos, marcados por, y encarnando prácticas y significados culturales diferentes, entran en conflícto. Esta definición de política cultural asume que las prácticas y los significados particularmente aquellos teorizados como marginales, opositivos, minoritarios, residuales, emergentes, alternativos y disidentes, entre otros, todos éstos concebidos en relación con un orden cultural dominante pueden ser la fuente de procesos que deben ser aceptados como políticos (pp. 25-26).

Ochoa Gautier (2003) define la política cultural como:

[...] la movilización de la cultura llevada a cabo por diferentes tipos de agentes - el Estado, los movimientos sociales, las industrias culturales, instituciones tales como museos u organizaciones turísticas, asociaciones de artistas y otros - con fines de transformación estética, organizacional, política, económica y/o social (p.20).

Para la Alcaldía de Bogotá (2005) las políticas culturales se refieren a:

[...] el resultado de la concertación entre los sectores sociales en torno a los aspectos logísticos, políticos, económicos y sociales, del campo cultural se espera que este proceso de concertación, así como su implementación, fortalezcan la relación entre el campo cultural y los otros campos sociales (p. 2).

Según la Unesco (1982), y como se referenció anteriormente, las políticas culturales hacen referencia al:

Conjunto de principios, prácticas y presupuestos que sirven de base para la intervención de los poderes públicos en la actividad cultural, radicada en su jurisdicción territorial, con el objeto de satisfacer las necesidades sociales de la población, en cualquiera de los sectores culturales (p. 2).

Como se puede inferir, más allá de las diversas definiciones, los principales elementos que caracterizan a la política cultura son la concertación so- 
cial, la existencia de una institucionalidad, la concepción multidimensional e integral de la cultura y la permanencia de la industria cultural. Se podría interpretar a partir de lo anterior la identificación de una necesidad para generar un diferencial con la concepción amplia de lo que es una política pública. No obstante, e independientemente del ámbito o sector de aplicación, como lo plantea el profesor Velásquez Gavilanes (2009), lo fundamental es la conciencia sobre lo que caracteriza el accionar del Estado. De esta manera, no se presenta el concepto de política cultural como algo lejano y disonante del entendimiento de las políticas públicas; en otras palabras, política cultura es equivalente a política pública cultural. Se da por hecho que la acción de la cultura se da en el marco público, aunque como se expondrá en el siguiente apartado, el relacionamiento con el mercado cada vez es mayor. El campo de acción de la cultura es amplio y rico a la vez. Por ello, el reto tanto de los tomadores de decisión como de los actores ejecutores del Plan Decenal, es intentar dar cabida a la singularidad y al complejo entramado de manifestaciones que son propias de la ciudadanía cundinamarquesa.

\section{Industrias culturales}

Uno de los grandes debates que se dan en torno a la cultura y al cómo fomentarla, es el riesgo de caer en lo que algunos llaman la "mercantilización de la cultura". Sin embargo, recientes aportes a la discusión, en especial las investigaciones del Banco Interamericano de Desarrollo (BID), proponen ir un poco más allá y estudiar objetivamente las posibilidades que ofrece lo que han dado en llamar la "Economía Naranja" y que definen de manera muy general como "el conjunto de actividades que de manera encadenada permiten que las ideas se transformen en bienes y servicios culturales, cuyo valor está determinado por su contenido de propiedad intelectual" (Buitrago \& Duque, 2013).

Ahora bien, lo anterior en ningún momento quiere decir que entonces toda producción cultural se debe pensar en torno a su posible conversión en, o tránsito hacia, bienes y servicios culturales. Sin duda estos dos términos pueden generar si no malestar, al menos serias dudas, más por un conjunto de resistencias que se han generado, y que sin duda son válidas, por la imposición que en ocasiones se da por agentes externos que transgreden toda posible alternativa cultural o tradición. No obstante, es muy importante tratar 
de superar estas diferencias y buscar puntos importantes de convergencia. Una posible alternativa es la promoción de la "Economía Naranja" y para ellos puede ser útil recordar que en el mundo la misma representa ingresos por 4.9 billones de dólares y en Colombia de 11.000 millones de dólares (Buitrago \& Duque, 2013).

Lo anterior, sugiere replantear una frase que en ocasiones puede ser común, pero que, sin lugar a dudas, no se sostiene: "la cultura es gratis". Eso evidentemente no es así. Alguien paga por la producción y promoción cultural. En ello puede radicar uno de los problemas, pues si bien estamos en un Estado Social de Derecho que garantiza un conjunto de derechos sociales, económicos y culturales; la sociedad y el Estado invierten en ello y, por lo tanto, la cultura no es gratis. Tan es así que en los ejercicios que se hacen con los encargados de asuntos culturales en diferentes municipios, uno de los temas que primero sale a flote es la falta de recursos.

En ese sentido, es menester revisar las oportunidades que se genera el tránsito hacia la economía naranja, donde uno de sus elementos, que no el único, es la industria cultural. Es decir, entender que todos los elementos que rodean la cultura, con un adecuado proceso de socialización, formación y apropiación; pueden a futuro ser el soporte para miles de ejercicios de emprendimiento y creación de empresa, que le aporten mucho más al conjunto de la economía. Esto en ningún momento va en contravía de las tradiciones o la protección a los derechos culturales.

Probablemente los elementos esenciales para poder hacer el tránsito hacia una adecuada comprensión de las industrias culturales en el marco de la economía naranja, que además incluye industrias creativas, artes y patrimonio, nuevos medios y software; es la información. No puede mantenerse un abismo entre economía y cultura, como si la segunda no dependiera de la primera en el mundo de hoy. Hay que lograr un ejercicio permanente de socialización de las grandes oportunidades que se presentan para los bienes y servicios culturales. Empero, esto hay que acompañarlo de un conjunto de instituciones fuertes que garanticen un soporte adecuado para la actividad cultural. Así como industriales y comerciantes han logrado incidir en el marco institucional, los actores de la economía naranja deben jugar un papel esencial en los acuerdos que originen nuevas instituciones para la promoción de la economía naranja. 
Industria, infraestructura, integración, inclusión e inspiración, cierran el marco general de la economía naranja, de la mano con la industria y las instituciones, como punto de partido y camino para la promoción de una economía cultural y creativa próspera y pujante: la economía naranja (Buitrago \& Duque, 2013). Es menester ir más allá del estado y buscar que la sociedad asuma el papel de la cultura y quiera ser partícipe en la producción cultural. Hasta aquí algunos pincelazos que se tienen en cuenta a continuación para exponer los elementos constitutivos de lo que ha sido la política cultural. En el siguiente apartado se expondrá el desarrollo de la institucionalidad, en el sentido más amplio, de las políticas culturales en otras latitudes, con el fin de observar algunas experiencias exitosas para ser tomadas como referente. 


\section{Capítulo 2}

\section{POLÍTIGAS GULTURALES DESDE EL CONTEXTO INTERNACIONAL}

Tas políticas públicas culturales deben estar en con-

Usonancia con el avance y desarrollo internacional. Precisamente, el proceso de policy transfer, como se refirió con anterioridad, ha estado presente en el desarrollo de la cultura en Colombia. Por ello, es importante conocer y referenciar el marco general al cual ha llegado la humanidad sobre la cultura, pero también las experiencias exitosas y los posibles referentes tanto conceptuales como técnicos para la formulación del Plan Decenal.

\section{Principales directrices y lineamientos interna- cionales sobre cultura}

A continuación se relacionan las principales declaraciones, planes e informes que sobre la cultura se han escrito y adoptado a nivel internacional. Dentro de las declaraciones emitidas sobre la cultura, se destaca la declaración de México sobre las políticas culturales. Esta declaración fue expedida en 1982 como producto de la Conferencia Mundial sobre las Políticas Culturales. Esta declaración define las líneas y orientaciones a seguir en el campo cultural y afirma que la cultura es esencial para un verdadero desarrollo del individuo y la sociedad. También indica que es necesario que desde las Políticas Culturales se establezcan las condiciones sociales y culturales que faciliten, estimulen y garanticen la creación artística e intelectual sin ningún tipo de discriminación (UNESCO, 1982). 
Como referente fundamental del proceso, se encuentra el Informe mundial de cultura y desarrollo "nuestra diversidad creativa" (UNESCO, 1996). Este documento fue elaborado por la Comisión Mundial de Cultura y Desarrollo, he indica en cuanto a políticas culturales, la necesidad de repensarlas y ampliar el concepto de estas para superar la perspectiva limitada las artes, planteando así, una consideración más completa e integral.

En el año 1997 se llevó a cabo el primer encuentro iberoamericano de Ministros de cultura en Venezuela, cuyo resultado se denotó en c. Esta declaración reafirma el compromiso de impulsar políticas culturales, fundamentadas en el concepto que ubica al hombre como sujeto y objeto de la cultura; constituyéndose las políticas de cultura en el eje del desarrollo humano.

En el año 1998 se aprobó el proyecto de plan de acción de políticas culturales para el desarrollo en la Conferencia Intergubernamental sobre Políticas Culturales para el Desarrollo, realizado en Estocolmo (UNESCO, 1998). Este plan recomienda cinco objetivos de política a los Estados Miembros de las Naciones Unidas: a) Hacer de la política cultural un componente central de la política de desarrollo; b) Promover la creatividad y la participación en la vida cultural; c) Reestructurar las políticas y las prácticas a fin de conservar y acentuar la importancia del patrimonio tangible e intangible, mueble e inmueble y fomentar las industrias culturales; d) Promover la diversidad cultural y lingǘstica dentro de y para la sociedad de información; y e) Disponer de más recursos humanos y financieros a disposición del desarrollo cultural.

Posteriormente, en el año 2001, como resultado de la V Conferencia Iberoamericana de Cultura realizada en Perú, se estableció la Declaración de Lima, en la cual se reafirma la necesidad de promover el desarrollo de legislaciones y políticas culturales activas y abiertas al mundo, pero fundamentada en sus acervos culturales, aprovechando así los procesos de integración y las alianzas multilaterales con a garantizar la diversidad cultural, y a la vez generar mecanismos para el fortalecimiento y la defensa de la identidad (Organización de Estados Iberoamericanos, 2001).

Reunidos en Barcelona los días 7 y 8 de mayo de 2004, en el IV Foro de Autoridades Locales para la Inclusión Social de Porto Alegre, en el marco del Foro Universal de las Culturas - Barcelona 2004, se aprobó la Agenda 21 
de la cultura como documento orientador de las políticas públicas de cultura y como contribución al desarrollo cultural de la humanidad. El documento establece los principios por los cuales se debe regir la cultura:

La diversidad cultural es el principal patrimonio de la humanidad. Es el producto de miles de años de historia, fruto de la contribución colectiva de todos los pueblos, a través de sus lenguas, imaginarios, tecnologías, prácticas y creaciones. La cultura adopta formas distintas, que siempre responden a modelos dinámicos de relación entre sociedades y territorios. La diversidad cultural contribuye a una existencia intelectual, afectiva, moral y espiritual más satisfactoria para todas las personas, y constituye uno de los elementos esenciales de transformación de la realidad urbana y social (Ajuntament de Barcelona. United Cities and Local Goverments, 2004).

En el año 2006 se aprobó en Uruguay la Carta cultural iberoamericana, durante la XVI Cumbre Iberoamericana de Jefes de Estado y de Gobierno. En dicha carta se reconoció la importancia de fortalecer el rol de la cultura en la promoción y consolidación de los derechos humanos e indicó la necesidad de que la formulación e implementación de las políticas culturales este en plena concordancia con la garantía y respeto de los derechos humanos (Carta Cultural Iberoamericana, 2006).

Finalmente, el lanzamiento de la Declaración de Friburgo sobre los derechos culturales tuvo lugar el 7 de mayo de 2007 en la Universidad de Friburgo y el, 8 de mayo de 2007, en el Palais des Nations de Ginebra. La declaración fue presentada por el Observatorio de la Diversidad y los Derechos Culturales de manera conjunta con la Organización Internacional de la Francofonia y la UNESCO. La Declaración de Friburgo contó con el apoyo de cincuenta expertos en derechos humanos, así como por una plataforma de diversas ONG. La Declaración reúne y hace explícitos diversos derechos culturales que ya están indicados de manera dispersa en diferentes instrumentos internacionales. Es declaración pone de presente la importancia de los derechos culturales, así como las dimensiones culturales de los demás derechos humanos (UNESCO, 2010).

Como se puede observar, ha existido una actividad constante en pro del desarrollo de la cultura a nivel mundial. Las diferentes declaraciones y manifestaciones muestran la importancia que tiene la cultura para la humanidad. $\mathrm{Y}$ en este sentido, se comprende el trasegar y evolución de las orientaciones 
para la construcción de las políticas públicas nacionales. Teniendo en cuenta lo anterior, a continuación se presenta un breve análisis de algunos países como referentes de políticas culturales.

\section{Referentes internacionales de políticas culturales}

Realizar una comparación de las políticas culturales puede ser un asunto complejo. Sin embargo, se presenta a continuación un análisis de algunos países que pueden ser considerados como referente en tanto su política pública en torno a la cultura tiene algunos rasgos particulares y diferenciales que han conducido al éxito. La selección de cada uno de los países corresponde a la importancia e impacto que sus políticas han registrado para sus poblaciones. La organización de la presentación por país corresponde a un orden alfabético. Vale la pena destacar que al final de la presentación de cada país se realizará un análisis de las variables que se podrían consideran como coincidentes.

\section{Alemania.}

La perspectiva de la cultura en Alemania contrasta severamente como progresista y conservadora. La vista progresiva hacia la cultura ha apoyado y promovido la política de la cultura, mientras que la perspectiva negativa ha reforzado la protección y preservación de los bienes culturales. Además del sistema de descentralización en Alemania, la política de la cultura fue aplicada por el gobierno central y local. Las instituciones culturales también están divididas en organizaciones afiliadas por el gobierno central y la auto-organización local como el sistema de gobierno binario. El gobierno central estableció la política de la cultura, asegurando la identidad, la protección de los bienes culturales, y que representa la posición de los países extranjeros (An, 2011). Por otro lado, la autonomía local formó la política de la cultura por el apoyo y la promoción. La Política de Cultura en Berlín también sigue la división de antes mencionada.

El noveno artículo de '2006-2011 koalitionsvereinbarung', las políticas pasivas se registran tales como la estabilidad, el mantenimiento y la comunicación, así la política activa se documenta como reforma, combinación, y la creación de empleo. La cultura que respalda las políticas en Berlín se subdivide en apoyo general, el apoyo de intercambio internacional y el apoyo de cultura minoritaria que dan una consideración positiva al sistema de apoyo 
decisivo. Sin embargo, Berlín tiene para llevar a cabo políticas más activas en la era de la internacionalización para salvar la cultura y las tradiciones y desarrollar una ciudad de la cultura. Para ello, la promoción del programa de cultura de los inmigrantes, el refuerzo de entrenamiento cultura y las políticas de entendimientos cultura mundial deben considerarse cuando se formula la política (An, 2011).

\section{Ghina.}

Las políticas culturales en China han sufrido cambios notables en las últimas décadas como un reflejo de la transformación política, económica y social del país. Los principales cambios en los regímenes de política cultural de China se abordan desde el tema de los derechos de propiedad intelectual y revela que el aparato administrativo complejo prohíbe la aplicación de las leyes de patentes y derechos de autor. Se discute el rápido desarrollo de las industrias culturales como una estrategia para el gobierno para mejorar la imagen global de China y promover el crecimiento económico. A pesar de la tendencia a la privatización y una mayor autonomía de los profesionales de la cultura, esas políticas demuestran que el Estado chino aún mantiene el control efectivo de la producción cultural, y por lo tanto limita en gran medida la libertad creativa en la sociedad (Zhang, 2015).

\section{Estados Unidos.}

La regulación de la cultura y las artes en los Estados Unidos - a nivel nacional- se remonta a una Ley Federal del año 1965, por la que se establecen dos agencias independientes a saber, el National Endowment for the Arts y el National Endowment for the Humanities. Valga aclarar que en el sistema estadounidense no existe el equivalente al Ministerio de Cultura; por el contrario, la cultura está condicionada por múltiples entidades privadas y públicas, tanto a nivel nacional como al de los Estados.

El NEA es un organismo gubernamental cuyo objeto es el avance de las artes, la creatividad y la innovación, así como el desarrollo y preservación de las mismas. Tal iniciativa se nutre de fondos públicos nacionales y estatales, así como de donaciones privadas. A nivel estatal, regional y local, existen más de cinco mil entidades públicas que interactúan con el NEA y comparten sus funciones de promoción cultural. 
La norma base para la actuación del NEA y el NEH fue promulgada en 1965, y aunque sujeta a reformas sucesivas, sigue conteniendo disposiciones iluminantes con respecto a la cultura. Puede destacarse el afirmar que la cultura es preocupación del Estado, para así entender el pasado, analizar el presente y predecir el futuro; establece la relación entre cultura y democracia, estructurando la colaboración entre las entidades adscritas en los distintos niveles de autoridad. Destaca el valor de las artes y humanidades como reflejo de la diversidad cultural estadounidense; alerta sobre el papel de potencia mundial, el cual debe descansar no sólo en riqueza y tecnología, sino además en la admiración por sus ideas y espíritu. Entiende que el sustento de una sociedad democrática y libre está en el respeto al multiculturalismo y la tolerancia a las nuevas ideas, por lo que es capital el apoyo financiero público a los artistas y su trabajo (Mark, 1969).

\section{Japón.}

La Gestión del patrimonio cultural es un tema que está atrayendo cada vez más atención en todo el mundo, el énfasis se desplaza de los problemas de conservación puras a las cuestiones de sostenibilidad futura de los sitios del patrimonio. La experiencia parece sugerir que es difícil preservar los sitios del patrimonio sin incrustarlos en un entorno social y económico vital culturales, mientras que al mismo tiempo existe el riesgo de que, al poner énfasis excesivo en la dimensión económica se conviertan en parques temáticos con la pérdida gradual de la autenticidad y la desintegración progresiva de su valor cultural e histórico.

Como menciona Ferilli, Sacco y Noda (2015) es necesario abordar estas cuestiones a través de un estudio comparativo de las dos ciudades patrimonio japonesas, Otaru y Yubari, tanto en la isla de Hokkaido del archipiélago japonés. El estudio de caso es de interés en que las dos ciudades son representativas de dos actitudes opuestas hacia la gestión del patrimonio: en Otaru, la revalorización de los activos culturales locales se ha realizado a través de la participación de la población local y un enfoque de inclusión social, mientras que en Yubari, el enfoque impulsado económicamente se ha desarrollado con el fin de mejorar el atractivo de la ciudad para los turistas.

Los resultados de este tipo de estrategias opuestas han ganado la atención internacional. El Municipio de Yubari ha ido a la quiebra y su política de 
atracción turística ha sido en gran medida ineficaz, mientras que el enfoque ascendente de la Ciudad de Otaru ha dado lugar a un rejuvenecimiento de la ciudad, que ahora está atrayendo a turistas desde el extranjero y ha sido testigo de una mejora considerable en la calidad de vida local y en el uso sostenible del patrimonio cultural local.

Promociones políticas recientes y exitosas en Yubari son necesarias para rescatar a la ciudad de su profunda crisis por medio del diálogo directo con los ciudadanos quienes proporcionan una prueba más de que la participación activa de la población local hace la diferencia. El análisis comparativo sugiere que las políticas de inclusión social parecen ser un componente esencial de los modelos viables de gestión de patrimonio, y que el hecho de integrar tal dimensión en el enfoque estratégico puede ser un error fatal.

\section{Sudáfrica.}

Para Sudáfrica en temas de tipo cultural se encarga el Departamento de Arte y Cultura (DAC) que sigue haciendo avances significativos en el posicionamiento de las industrias culturales y creativas como uno de los principales motores del crecimiento económico y la creación de empleo en Sudáfrica. El éxito del sector de la cultura y las artes también depende de una gobernanza eficaz, la infraestructura y el desarrollo de habilidades, asociaciones, investigación, intercambio de información y el desarrollo empresarial (Czerniewicz \& Brown, 2009).

En este contexto, el departamento está comprometido a apoyar una serie de cambios emergentes en las artes, la cultura y el sector del patrimonio en los próximos cinco años. Estos cambios tienen el potencial de aumentar el crecimiento y desarrollo de la forma significativa generando sector. Incluyen abordar una serie de deficiencias en el entorno político y reglamentario para fortalecer la gobernabilidad en el sector, aumentar la inversión y mejorar la información y estadísticas para la planificación más eficaz y la toma de decisiones.

\section{Ucrania.}

La política cultural es un timón para mejorar todas las características que hace de la cultura una armonía. La política cultural de Ucrania en la era del comunismo abarca toda la actividad intelectual del socialismo que apuntan a la perfección del comunismo. Estaba dividido en gran medida 
en el período de desarrollo del socialismo y del avance de la sociedad comunitaria. Por supuesto, cada propósito era realizar una sovietización que era idealista y típica. Mientras tanto, hubo un mapa específico y política de ruta para la ucranización en el aspecto inverso (voluntariamente o no). Este debate fue dibujado claramente en el vórtice del proceso de formación de la Federación Soviética. Eso fue de acuerdo con la intención del Consejo Central de Ucrania en 1917, la lucha nacionalista liderado por Petlyura en 1919 y la descentralización en 1924 cuando se estableció la constitución en un primer momento (Choi, 2012).

Como la cultura está estrechamente relacionada con los diferentes ámbitos de la sociedad (la educación, la industria, la tecnología, el arte y la literatura, etc.), los problemas sociales con los que Ucrania se enfrenta se irán resolviendo de manera conjunta entre los diferentes ámbitos. El sistema de apoyo a la cultura que se adoptó en la línea del gobierno estaba poniendo más y más avances en 1920, los años 1960 y luego en 1986. Al principio, el movimiento cultural de Ucrania jugó un papel de puente cuando la Comunidad de Estados Independientes (CEI) se constituyó con Rusia y ayudó con la independencia de Ucrania (Choi, 2012).

\section{Variables frecuentes en los países referentes.}

De acuerdo a cada uno de los países anteriormente mencionados e identificados como referentes exitosos en el tema cultural, se encuentra que las variables exitosas en la gestión cultural de los mismos son:

- La administración de los asuntos culturales se debe a una organización adecuada de las instituciones y de una interrelación de las mismas lo que causa un éxito en la cobertura y atención a toda la población.

- Creación de asociaciones mixtas entre las entidades privadas y públicas que aseguran la gestión cultural y el impulso de los sectores como en el caso del sector musical en Italia.

- Monitoreo y supervisión constante de las estrategias de promoción y financiación por parte de los entes encargados de la gestión cultural.

- Intersectorialidad directa con el ministerio de educación, se entiende a la educación como gestora de la cultura. A mayor educación, mayor cultura. 
- Existen leyes de mecenazgo cultural, lo que hace que las empresas privadas se sientan comprometidas con la gestión y fomento de la cultura.

- El éxito del sector de la cultura y las artes también depende de una gobernanza eficaz, la infraestructura y el desarrollo de habilidades, asociaciones, investigación, intercambio de información y el desarrollo empresarial 



\section{Capítulo 3}

\section{GONTEXTO DE LA GULTURA EN COLOMBIA}

L sector cultural ha tenido un crecimiento im-
portante en su desarrollo en los últimos años. La institucionalidad, tanto desde el orden central nacional como el local, ha tenido un surgimiento en la medida que los actores han denotado su importancia y han generado, como lo denomina Kingdon (1995), una ventana de oportunidad. Esto quiere significar que tanto la institucionalidad como las propias acciones, o políticas públicas, han surgido en momentos en los cuales han confluido una serie de arenas comunes, como por ejemplo el interés de actuar para la cultura. En el presente capítulo se presentan algunos rasgos institucionales desde la óptica organizacional y normativa.

\section{Antecedentes de políticas culturales en Latinoamérica y Colombia}

Como lo reseña el Municipio de Facatativá (2015), conforme a la historia latinoamericana y colombiana, se pueden distinguir tres periodos partiendo desde los procesos independentistas. El primer periodo, corresponde a la etapa Republicana del siglo XIX, caracterizado por la creación de instituciones culturales sectoriales enfocadas a la atención de campos particulares de las artes y el patrimonio; en el caso colombiano que se destaca como uno de los más antiguos de Latinoamérica. De otra parte en este periodo encontramos como la Comisión coreo- 
gráfica liderada por el general y geógrafo italiano Agustín Codazzi permitió avanzar en el conocimiento geográfico del país, y en su conocimiento cultural (p. 10).

Un segundo periodo se ubica en la primera mitad del siglo XX, donde encontramos que los movimientos sociales y políticos generados en la época fueron esenciales; en el contexto colombiano encontramos que dentro de la denominada "República Liberal" se dio un proceso que se podría denominar "democratización de la Cultura", en este periodo se destacan la reestructuración de la biblioteca Nacional, el proyecto de Cultura aldeana, la realización de salones nacionales de artes visuales; la creación del Instituto etnográfico nacional, el servicio arqueológico nacional y la Radio Difusora Nacional de Colombia. Finalizada la "República Liberal", aunque este proceso pierde un poco de impulso, también se dan hitos culturales significativos como las Hojas de Cultura Popular de Colombia, esto dentro de una concepción clásica de la cultura a la que algunos denominan "integrista" (Municipio de Facatativá, 2015, p. 10)

En el tercer periodo que corresponde a la segunda mitad del siglo XX, se genera una institucionalidad cultural más sólida y estructurada, se redefinen los campos culturales, y juegan un papel más protagónico los medios de comunicación. En Colombia encontramos al inicio de este periodo un hecho de gran relevancia para el desarrollo Cultural como lo fue el inicio de la televisión en 1954 durante la dictadura de Gustavo Rojas Pinilla. Posteriormente dentro del denominado Frente Nacional encontramos una mayor estructuración de la acción estatal en el campo de la cultura, proceso que tiene su momento preponderante con la Creación del Instituto Colombiano de Cultura (Colcultura) en 1968, lo cual permitió agrupar diferentes instituciones del estado que venían desarrollando de manera desligada acciones en el campo cultural y desarrollar políticas culturales articuladas (Municipio de Facatativá, 2015, p, 11).

Terminado el Frente Nacional se da un proceso de impulso al desarrollo cultural, principalmente en cuanto a la generación de publicaciones culturales, el desarrollo de las bellas artes y el fortalecimiento de la biblioteca nacional. Este desarrollo cultural estuvo marcado por la realización de la Conferencia Intergubernamental sobre Políticas Culturales en América Latina y el Caribe en 1978, celebrada en Bogotá, antecedente 
esencial de la Conferencia Mundial de Políticas Culturales celebrada en México 1982, como se referenció anteriormente (Municipio de Facatativá, 2015, p, 11)

En la primera mitad de la década de los ochenta se le dio un impulso importante en desarrollo cultural, haciendo énfasis en el fortalecimiento de la identidad cultural de la nación; generando un especial interés por la formulación de políticas culturales regionales. En la segunda mitad de esta década se enfatizó en el patrimonio cultural y se dio un impulso a la consolidación de organismos regionales asesores de cultura. (Municipio de Facatativá, 2015, p, 11).

\section{Ministerio de Gultura}

Hay que reconocer que el país está cimentado en una diversidad y heterogeneidad en la cultura. Colombia es un país que ha construido su cultura en lo artístico, patrimonial y en dinámicas permanentes. El Estado colombiano a través de la Constitución Política de 1991 (Art. 7), reconoce a Colombia como un país pluricultural y diverso, sentando las bases para la conservación, protección y salvaguardia de esa diversidad cultural.

En términos políticos el Estado tiene la obligación de consolidar un ámbito cultural articulado que permita responder a los retos que trae el siglo XXI. Por su parte, el Ministerio de Cultura, como ente rector del sector, está llamado a formular y fortalecer las políticas sectoriales a través de programas y acciones para afrontar las necesidades y soluciones a problemas públicos en el ámbito cultural y artístico. La actual política de cultura se encuentra desagregada en distintos niveles y que han ido apareciendo a medida que surgen las necesidades de atención a ciertos temas. La política cultural del país se ha cimentado sobre las bases que el Ministerio ha construido. A continuación se relacionan las principales políticas que actualmente se encuentran en vigencia y que son de competencia y aplicación por parte del Ministerio de Cultura. 
Tabla 2. Principales políticas culturales formuladas e implementadas por el Ministerio de Cultura

\section{Política}

\begin{tabular}{|c|c|}
\hline Política & Descripción \\
\hline $\begin{array}{l}\text { Protección del } \\
\text { Patrimonio } \\
\text { Cultural Mueble }\end{array}$ & $\begin{array}{l}\text { El Ministerio de Cultura adoptó en } 2014 \text { esta política, al considerar } \\
\text { que el patrimonio Cultural mueble y los bienes muebles de interés } \\
\text { cultural son fundamentales en la construcción de ciudadanía y el } \\
\text { fortalecimiento del sentido de pertenencia de los colombianos, } \\
\text { en la medida que "los objetos que los seres humanos producimos } \\
\text { son parte constitutiva de la vida, de las dinámicas y las relaciones } \\
\text { sociales y representan no solo las ideas, sino, en general, la cultura" } \\
\text { (Ministerio de Cultura, 2011). }\end{array}$ \\
\hline $\begin{array}{l}\text { Conocimiento, } \\
\text { la salvaguardia } \\
\text { y el fomento de } \\
\text { la alimentación } \\
\text { y las cocinas } \\
\text { tradicionales de } \\
\text { Colombia }\end{array}$ & $\begin{array}{l}\text { El Ministerio de Cultura adoptó en el año } 2009 \text { la Política de } \\
\text { Salvaguardia del Patrimonio Cultural Inmaterial. En el marco de } \\
\text { esta política, la cultura culinaria tradicional se presenta como un } \\
\text { campo ideal para comprender cómo los conocimientos y prácticas } \\
\text { de la cocina generan en las personas y colectivos sociales vínculos } \\
\text { de cohesión e identidad con su región y su comunidad. }\end{array}$ \\
\hline Artes & $\begin{array}{l}\text { La política para el campo de las artes ha partido de los antecedentes } \\
\text { del proceso de construcción de lineamientos en diferentes áreas. }\end{array}$ \\
\hline $\begin{array}{l}\text { Gestión, } \\
\text { protección y } \\
\text { salvaguardia } \\
\text { del patrimonio } \\
\text { cultural }\end{array}$ & $\begin{array}{l}\text { Con esta política se ha dado un progresivo fortalecimiento de } \\
\text { instituciones como la Biblioteca Nacional, el Museo Nacional, el } \\
\text { Archivo General de la Nación y los predecesores del actual Instituto } \\
\text { Colombiano de Antropología e Historia (Icanh). }\end{array}$ \\
\hline $\begin{array}{l}\text { Salvaguardia } \\
\text { del patrimonio } \\
\text { cultural } \\
\text { inmaterial }\end{array}$ & $\begin{array}{l}\text { Esta política del Ministerio comprende no sólo los usos, } \\
\text { representaciones, expresiones, conocimientos y técnicas de un grupo } \\
\text { humano, que hunden sus raíces en el pasado y que se perpetúan en } \\
\text { la memoria colectiva, sino también los apropiados socialmente en la } \\
\text { vida contemporánea de las comunidades y colectividades sociales. }\end{array}$ \\
\hline Museos & $\begin{array}{l}\text { El Ministerio de Cultura, a través del Museo Nacional, tiene bajo su } \\
\text { responsabilidad la protección y desarrollo de los museos existentes } \\
\text { y la adopción de incentivos para la creación de nuevos museos en } \\
\text { todas las áreas del Patrimonio Cultural de la Nación. }\end{array}$ \\
\hline Archivos & $\begin{array}{l}\text { El Archivo General de la Nación (AGN) se propone fortalecer y } \\
\text { actualizar los lineamientos relativos tanto a la salvaguarda del } \\
\text { patrimonio documental colombiano como a la modernización de } \\
\text { los archivos públicos. }\end{array}$ \\
\hline
\end{tabular}


Por sus características propias, su enorme complejidad y su papel

Protección a la diversidad etnolingüística

Diversidad cultural eminente dentro de la cultura y la identidad de un pueblo, las lenguas ameritan un tratamiento específico y es la conciencia de la necesidad de una atención particular a esta realidad la que mueve al Ministerio a la construcción de una política focalizada hacia la protección de lenguas.

Colombia es un país reconocido por su compleja y rica diversidad cultural que se expresa en una gran pluralidad de identidades y de expresiones culturales de los pueblos y comunidades que forman la nación.

Turismo cultural

La política de turismo cultural resalta la potencialidad para articular procesos de identificación, valoración, competitividad, sostenibilidad y difusión del patrimonio cultural.

El fin de esta política es asegurar las posibilidades de acceso de toda la población colombiana a la lectura, la información y al conocimiento, sin discriminaciones de ningún tipo, y que garantice

Lectura y

bibliotecas para las generaciones presentes y futuras la reunión, conservación, control y divulgación de su patrimonio bibliográfico y documental en los diferentes soportes, para conocimiento y memoria del país, de su historia y de su cultura.

Comunicación

En esta política se plasman los principales criterios, procedimientos y programas que configuran la política pública de comunicación que se implementa desde el Ministerio de Cultura.

El Ministerio ha abordado el tema y ha entendido que el asunto no

Cultura digital es sólo de tecnologías o de consumo, sino que alrededor de los usos de estos medios se ha construido una nueva cultura, una serie de nuevas maneras de estar juntos: la cultura digital.

La política cinematográfica se basa en el reconocimiento que "el Cinematográfica cine constituye una expresión cultural generadora de identidad social" (Ministerio de Cultura, 2011).

Emprendimiento y las Industrias culturales

En las últimas décadas, tanto el concepto industrias culturales y creativas, como la percepción del mismo en América Latina, han experimentado severos y positivos cambios, que se derivan de su desarrollo y que, a su vez, inciden en su crecimiento. 


\begin{tabular}{|c|c|}
\hline Política & Descripción \\
\hline Concertación & $\begin{array}{l}\text { Uno de los pilares del desarrollo de la cultura en el país es } \\
\text { la concertación, que a su vez, es uno de los componentes } \\
\text { fundamentales de la sostenibilidad cultural. El apoyo del Estado, al } \\
\text { fortalecimiento de instituciones y organizaciones culturales, es una } \\
\text { labor que permite la afirmación del tejido cultural de la sociedad, } \\
\text { la promoción de determinadas áreas de la cultura entendidas como } \\
\text { prioritarias y el reconocimiento de proyectos con influencia positiva } \\
\text { en las comunidades. }\end{array}$ \\
\hline Estímulos & $\begin{array}{l}\text { La creación es una de las dimensiones fundamentales de la cultura. } \\
\text { De esta manera, la creación combina lo individual con lo social, el } \\
\text { pasado con el futuro. La creación, a su vez, se expresa de múltiples } \\
\text { maneras y está presente en la amplia gama de las manifestaciones } \\
\text { culturales y artísticas de un pueblo. }\end{array}$ \\
\hline $\begin{array}{l}\text { Infraestructura } \\
\text { cultural }\end{array}$ & $\begin{array}{l}\text { La infraestructura para la cultura o la infraestructura cultural, es, } \\
\text { sin duda, una poderosa herramienta para promover el desarrollo } \\
\text { económico y social y para integrar a las comunidades y generar su } \\
\text { bienestar. }\end{array}$ \\
\hline $\begin{array}{c}\text { Gestión } \\
\text { internacional de } \\
\text { la cultura }\end{array}$ & $\begin{array}{l}\text { La gestión internacional de la cultura colombiana, en un contexto } \\
\text { marcado por la globalización y la cooperación dinámica entre } \\
\text { países y pueblos, genera oportunidades positivas para el sector } \\
\text { cultural del país, contribuyendo así al desarrollo de sus capacidades } \\
\text { creativas, empresariales e institucionales, a la construcción del tejido } \\
\text { social y al fortalecimiento de esquemas de convivencia a partir del } \\
\text { reconocimiento y la promoción de la diversidad cultural. }\end{array}$ \\
\hline Casas de cultura & $\begin{array}{l}\text { Las políticas para las casas de la cultura deben ser consecuentes } \\
\text { con el compromiso de enmarcarlas dentro de una concepción } \\
\text { del desarrollo como proceso creativo, cuya finalidad última sea } \\
\text { lograr que cada individuo y cada grupo humano pueda expresar } \\
\text { plenamente su creatividad y aportar, desde ella, a la construcción } \\
\text { de un mundo más próspero. }\end{array}$ \\
\hline
\end{tabular}

Fuente: Ministerio de Cultura (2011).

Como se puede observar en la Tabla 2, el Ministerio de Cultura ha emitido una serie de políticas culturales que abordan temas tanto del orden institucional como del desarrollo de las propias áreas de interés principales. 
Estas acciones establecidas son fundamentales en la medida que marcan la hoja de ruta del país y son la "carta de navegación" de los departamentos y municipios. En atención a ello, y como se verá en el Capítulo 5, la política propuesta para el Departamento de Cundinamarca por medio del Plan Decenal, contiene de fondo los rasgos y conceptos que plantea el Ministerio. Vale la pena destacar anticipadamente, que el Plan Decenal se desarrolló con unas metas y estrategias que son diferenciales y que se esperan solucionen las problemáticas del Departamento, para así contribuir consecuentemente con el cumplimiento de las políticas nacionales.

\section{Marco jurídico de la cultura en Colombia}

En Colombia se ha generado un desarrollo normativo con rango constitucional a partir de la noción de cultura en búsqueda de la entidad nacional, la Constitución Política de Colombia regula el concepto cultural conforme al artículo 70 de la Constitución Política de Colombia (1991) que establece que

El Estado tiene el deber de promover y fomentar el acceso a la cultura de todos los colombianos en igualdad de oportunidades, por medio de la educación permanente y la enseñanza científica, técnica, artística y profesional en todas las etapas del proceso de creación de la identidad nacional.

La cultura en sus diversas manifestaciones es fundamento de la nacionalidad. El Estado reconoce la igualdad y dignidad de todas las que conviven en el país. El Estado promoverá la investigación, la ciencia, el desarrollo y la difusión de los valores culturales de la Nación.

Según el Departamento Nacional de Planeación DNP (2015) desde el punto de vista administrativo el sector de la cultura en Colombia se reorganizó en el año 1997 cuando se expidió la Ley General de Cultura, Ley 397 de 1997, y se organizó como sector liderado por el Ministerio de Cultura. Esta ley regula en su Artículo $1^{\circ}$ los principales elementos a tener en cuenta para comprender el concepto de la cultura en Colombia, por otro lado, se resaltan los Artículos 2,8,17 y 29 que delimitan los elementos claves a tener en cuenta para diseñar una política pública cultural:

\section{Normas relacionadas con la cultura.}

A continuación se relacionan las principales Leyes y Decretos relacionadas con la cultura. 
Tabla 3. Listado de normas relacionadas con la cultura desde 1993 hasta 2013

\begin{tabular}{|c|c|}
\hline Norma & Descripción \\
\hline Ley 98 de 1993 & $\begin{array}{l}\text { Por medio de la cual se dictan normas sobre democratización } \\
\text { y fomento del libro (Congreso de la República de Colombia, } \\
\text { 1993). }\end{array}$ \\
\hline Ley 397 de 1997 & $\begin{array}{l}\text { Normas sobre patrimonio cultural, fomentos y estímulos a la } \\
\text { cultura, se crea el Ministerio de la Cultura (Congreso de la } \\
\text { República de Colombia, 1997). }\end{array}$ \\
\hline Decreto 1589 de 1998 & $\begin{array}{l}\text { Por el cual se reglamenta el Sistema Nacional de Cultura } \\
\text { (Samper Pizano, 1998). }\end{array}$ \\
\hline Ley 666 de 2001 & $\begin{array}{l}\text { Estampilla pro-cultura (Congreso de la República de } \\
\text { Colombia, 2001). }\end{array}$ \\
\hline Decreto 826 de 2003 & Consejo Nacional Libro y Lectura (Uribe Vélez, 2003). \\
\hline Decreto 1746 de 2003 & $\begin{array}{l}\text { Por el cual se determinan los objetivos y estructura orgánica } \\
\text { del Ministerio de Cultura y se dictan otras disposiciones } \\
\text { (Uribe Vélez, 2003). }\end{array}$ \\
\hline Ley 814 de 2003 & $\begin{array}{l}\text { Por la cual se dictan normas para el fomento de la actividad } \\
\text { cinematográfica en Colombia (Congreso de la República de } \\
\text { Colombia, 2003). }\end{array}$ \\
\hline Decreto 352 de 2004 & $\begin{array}{l}\text { Reglamentaria de la Ley } 814 \text { de } 2003 \text {. Por el cual se reglamenta } \\
\text { los artículos } 7^{\circ}, 9^{\circ}, 12^{\circ}, 14^{\circ} \text { y } 16^{\circ} \text { de la Ley } 814 \text { de } 2003 \\
\text { (fomento de la actividad cinematográfica) (Uribe Vélez, 2004). }\end{array}$ \\
\hline Decreto 1313 de 2008 & $\begin{array}{l}\text { Artículo } 1^{\circ} \text {. Consejo Nacional de Patrimonio Cultural. De } \\
\text { conformidad con el artículo } 4^{\circ} \text { de la Ley } 1185 \text { de } 2008 \text {, } \\
\text { modificatorio del artículo } 7^{\circ} \text { de la Ley } 397 \text { de } 1997 \text {, el Consejo } \\
\text { Nacional de Patrimonio Cultural es el órgano encargado de } \\
\text { asesorar al Gobierno Nacional en cuanto a la salvaguardia, } \\
\text { protección y manejo del patrimonio cultural de la Nación } \\
\text { (Uribe Vélez, 2008). }\end{array}$ \\
\hline Ley 1185 de 2008 & $\begin{array}{l}\text { Por la cual se modifica y adiciona la Ley } 397 \text { de } 1997 \text {-Ley } \\
\text { General de Cultura- y se dictan otras disposiciones (Congreso } \\
\text { de la República de Colombia, 2008). }\end{array}$ \\
\hline
\end{tabular}


Norma

Decreto 763 de 2009

Ley 1493 de 2011

Ley 1556 de 2012

Ley 1675 de 2013

\section{Descripción}

Por medio del cual se reglamentan parcialmente las leyes 814 de 2003 y 397 de 1997, modificada por medio de la Ley 1185 de 2008, en lo correspondiente al Patrimonio Cultural de la Nación de naturaleza material (Uribe Vélez, Decreto 763 de 2009. Por medio del cual se reglamentan parcialmente las leyes 814 de 2003 y 397 de 1997, modificada por medio de la Ley 1185 de 2008, en lo correspondiente al Patrimonio Cultural de la Nación de naturaleza material, 2009).

Por la cual se toman medidas para formalizar el sector del espectáculo público de las artes escénicas, se otorgan competencias de inspección, vigilancia y control sobre las sociedades de gestión colectiva y se dictan otras disposiciones (Congreso de la República de Colombia, 2011).

Por la cual se fomenta el territorio nacional como escenario para el rodaje de obras cinematográficas (Congreso de la República de Colombia, 2012).

Por medio de la cual se reglamentan los artículos 63, 70 y 72 de la Constitución Política de Colombia en lo relativo al patrimonio cultural sumergido (Congreso de la República de Colombia, 2013).

Fuentes: Congreso y Presidencia de la República de Colombia

\section{Documentos de política económica y social relacionados con la cultura.}

Los CONPES como instrumentos para la planeación económica y social del país son una importante herramienta para el desarrollo de la cultura. Por ejemplo, el CONPES 3659 de 2010 que establece la política nacional para la promoción de las industrias culturales señala que:

El objetivo central de esta Política es aprovechar el potencial competitivo de las industrias culturales, aumentar su participación en la generación del ingreso y el empleo nacionales, y alcanzar elevados niveles de productividad. Se estructura en cinco líneas estratégicas orientadas a superar los obstáculos identificados en la esfera de la circulación de bienes y servicios de las industrias culturales - especialmente para las empresas de menor tamaño del sector-, y a ampliar el acceso al financiamiento y a los instrumentos públicos de desarrollo empresarial. Se enfatiza también en el componente de formación del capital humano 
de la industria, y en la promoción del uso de nuevas tecnologías. Por último, se propone una línea estratégica orientada a reducir la concentración regional de las industrias culturales, mediante el aprovechamiento del potencial local y de experiencias piloto que en ese sentido actualmente se están desarrollando en diferentes regiones del país (Departamento Nacional de Planeación, 2010).

A continuación se relacionan los CONPES sobre cultura que se han emitido en orden cronológico.

Tabla 4. CONPES sobre cultura entre 2002 y 2014

\begin{tabular}{|c|c|}
\hline GONPES & Descripción \\
\hline 3162 de 2002 & $\begin{array}{l}\text { Lineamientos para la sostenibilidad del Plan Nacional de Cultura } \\
2001-2010 \text { "Hacia una ciudadanía democrática cultural" } \\
\text { (Departamento Nacional de Planeación, 2002). }\end{array}$ \\
\hline 3255 de 2003 & $\begin{array}{l}\text { Lineamientos de política para la distribución del } 25 \% \text { de los } \\
\text { recursos territoriales provenientes del incremento del } 4 \% \text { del IVA } \\
\text { a la telefonía móvil (Departamento Nacional de Planeación, 2003). }\end{array}$ \\
\hline 3409 de 2006 & $\begin{array}{l}\text { Lineamientos para el fortalecimiento del Plan Nacional de Música } \\
\text { para la Convivencia (Departamento Nacional de Planeación, 2006). }\end{array}$ \\
\hline 3462 de 2007 & $\begin{array}{l}\text { Lineamientos para el fortalecimiento de la cinematografía en } \\
\text { Colombia (Departamento Nacional de Planeación, 2007). }\end{array}$ \\
\hline 3658 de 2010 & $\begin{array}{l}\text { Lineamientos de Política para la recuperación de los centros } \\
\text { históricos en Colombia (Departamento Nacional de Planeación, } \\
\text { 2010). }\end{array}$ \\
\hline 3659 de 2010 & $\begin{array}{l}\text { Política Nacional para la promoción de las industrias culturales en } \\
\text { Colombia (Departamento Nacional de Planeación, CONPES } 3659 . \\
\text { Política Nacional para la promoción de las industrias culturales en } \\
\text { Colombia, 2010). }\end{array}$ \\
\hline 3803 de 2014 & $\begin{array}{l}\text { Política Nacional para la preservación del Paisaje Cultural Cafetero } \\
\text { de Colombia (Departamento Nacional de Planeación, 2014). }\end{array}$ \\
\hline
\end{tabular}

Fuente: Departamento Nacional de Planeación

\section{Análisis de la regulación de la cultura en Colombia}

La normatividad reseñada - que incluye leyes y decretos- puede ser agrupada y estudiada en cuatro grandes temáticas, a saber: obras cinematográfi- 
cas, artes escénicas, patrimonio cultural en sus diversas formas, y libros. Se procederá a enumerar y analizar cada una de estas temáticas y sus normas.

\section{Artes escénicas.}

LEY 1493 DE 2011 ARTES ESGÉNICAS. Esta ley hace referencia a los aspectos fiscales que atañen al desarrollo de las actividades contempladas como artes escénicas; para tales aspectos nombra las deducciones por inversiones, retención en la fuente por servicios artísticos de extranjeros, así como los servicios artísticos excluidos del IVA. Crea la contribución parafiscal cultural, cuyo hecho generador será la boletería de espectáculos públicos de las artes escénicas, bien del orden municipal o bien del orden distrital; especifica al sujeto activo y al pasivo de la contribución, así como también a la declaración y pago que deben realizar los productores permanentes. Establece el Registro de Productores de Espectáculos Públicos de las Artes Escénicas.

Refiere el alcance de la contribución parafiscal, y crea una cuenta especial para la administración de tal contribución que estará a cargo del Ministerio de Cultura. De igual manera, regula los escenarios habilitados para la realización de espectáculos públicos y la racionalización de trámites y requisitos especiales para escenarios habilitados y no habilitados.

Se ordena la creación de la ventanilla única de registro y atención a los productores de los espectáculos públicos de las artes escénicas por parte de las capitales de departamento; asimismo, ordena a las autoridades municipales y distritales la promoción y la facilitación en la realización de estas actividades en parques; y habilita la vigilancia y control de estos espectáculos en cualquier tiempo.

Aunado a ello, regula el pago de derechos de autor y las declaraciones de contribución parafiscal; establece límite a los gastos de funcionamiento; enuncia la competencias y facultades de la Unidad Administrativa Especial - Dirección Nacional de Derechos de Autor del Ministerio del Interior; enuncia las medidas cautelares inmediatas que el director de la Unidad Administrativa Especial podrá adoptar en desarrollo de sus funciones. Contempla la toma de posesión, por parte de la Dirección Nacional de Derechos de Autor, de una sociedad de gestión colectiva, y los efectos de la misma; por otro lado, establece los beneficios para los contribuyentes cumplidos. 


\section{Cultura.}

DEGRETO 1589 DE 1998, SISTEMA NAGIONAL DE GULTURA. Este decreto define al Sistema Nacional de Cultura como un "conjunto de instancias, espacios de participación y procesos de desarrollo institucional, planificación, financiación, formación, e información articulados entre sí, que posibilitan el desarrollo cultural y el acceso de la comunidad a los bienes y servicios culturales," cuyo objeto está en contribuir y garantizar acceso a manifestaciones, bienes y servicios culturales, así como también está en promover la creatividad de los ciudadanos colombianos.

La norma integra las instancias del Sistema Nacional de Cultura mediante multitud de órganos, entre los que destacan el Ministerio de Cultura, las entidades y oficinas culturales territoriales, los Fondos Mixtos para la Promoción de la Cultura y las Artes, y muchas más entidades públicas o privadas que realicen actividades de desarrollo, financiamiento, fomento, o promoción de actividades culturales y artísticas, en cualquier nivel.

LEY 666 DE 2001, ESTAMPILLA PROGULTURA. Mediante la modificación del artículo 38 de la Ley 397 de 1997, la norma faculta a las asambleas departamentales, y a los concejos para que ordenen la emisión de una estampilla "Procultura", cuyos recursos serán por ellos administrados, siempre con destino a proyectos que concuerden con los planes nacionales y locales de cultura.

DEGRETO 1746 DE 2003, MINISTERIO DE GULTURA, COLDEPORTES, INSTITUTO GARO Y GUERVO. Lo dispuesto en el decreto establece las entidades administrativas de cultura - con o sin personería jurídica-, así como también la oficina jurídica y de planeación del Ministerio de Cultura.

Crea además la Dirección de Patrimonio, de Artes, de Comunicaciones, de Cinematografía, de Etnocultura y Fomento Regional, de Infancia y Juventud; adscribe al Ministerio unidades administrativas especiales, tales como el Museo Nacional y la Biblioteca Nacional.

LEY 1185 DE 2008. MODIFIGAGIÓN LEY GENERAL DE GULTURA. La ley define los elementos que integran el patrimonio cultural de la nación, tanto material como inmaterial. Establece un régimen especial de protección para la protección y sostenibilidad de los bienes culturales materiales y manifestaciones inmateriales, conforme a lo que reglamente el Ministerio de Cultura. 
Pone a cargo del Ministerio de Cultura, el Sistema Nacional de Patrimonio Cultural de la Nación, compuesto además por el ICANH, el Archivo General de la Nación, el Consejo Nacional de Patrimonio Cultural, entre otros. Define el patrimonio arqueológico y lo pone bajo tutela y dirección del Instituto Colombiano de Antropología e Historia -ICANH--, quien será el encargado de todo su manejo y regulación.

Reemplaza al antiguo Consejo de Monumentos Nacionales por el Consejo Nacional de Patrimonio Cultural, órgano encargado de asesorar al Gobierno Nacional en cuanto a la salvaguardia, protección y manejo del patrimonio cultural de la Nación. La ley crea los consejos departamentales y distritales de patrimonio cultural y reglamenta sus respectivas funciones.

Describe el trámite para la declaratoria de bienes de interés cultural los cuales son inembargables, imprescriptibles e inalienables. Se le asigna al Ministerio de Cultura la tarea de reglamentar el plan especial de manejo y protección de los bienes de interés cultural; a su vez, se establecen las faltas contra el patrimonio cultural de la Nación, ya sean de tipo administrativo o disciplinario, facultando a determinadas autoridades - como el Ministerio, el ICANH y el Archivo Nacional- la imposición y ejecución de las mismas.

La ley, por último, ordena la creación del Comité de Clasificación de Películas, cuya función es disponer y autorizar sobre la exhibición de películas en salas de cine o sitios públicos.

\section{Libros.}

LEY 98 DE 1993, DEMOGRATIZAGIÓN Y FOMENTO DEL LIBRO GOLOMBIANO. La ley tiene por objeto democratizar de manera efectiva el libro a nivel nacional, generando un uso más amplio como medio principal de difusión de la cultura, trasmisión del conocimiento y fomento de la investigación científica y social. Cobija la ley a libros, revistas, folletos, coleccionables seriados o publicaciones de carácter científico o cultural, aquellos editados, producidos e impresos en la República de Colombia; así mismo menciona la ley que las editoriales son personas jurídicas responsables económica y legalmente de las ediciones de los libros a nivel nacional.

Ordena que los suministros de materias primas para la elaboración de libros sean supervisados por el Instituto Colombiano de Normas Técnicas 
-ICONTEC-, y declara exentos los papeles importados para la edición y fabricación de libros. De otro lado, la ley promueve la formación de personal idóneo para el sector, mediante la creación de un Centro Nacional de Capacitación. Ordena el uso de códigos de barras, así como el registro con ISBN e ISSN. La ley fomenta la comercialización y promoción de libros, mediante tarifas postales reducidas, la celebración periódica de ferias, la adquisición pública de ejemplares. Así mismo, prevé beneficios tributarios para las empresas que se dediquen exclusivamente a la edición de libros.

DEGRETO 826 DE 2003, GONSEJO NAGIONAL DEL LIBRO Y LA LEGTURA. El decreto determina quienes serán los miembros del Consejo Nacional del Libro y la Lectura, cuya función será asesorar al gobierno nacional -a través del Ministerio de Cultura- en los asuntos relativos al libro y la lectura; la secretaria técnica del citado consejo la ejercerá el director de la Biblioteca Nacional de Colombia, cuyas funciones están prescritas en el decreto mismo.

\section{Obras cinematográficas.}

LEY 814 DE 2003, FOMENTO DE LA AGTIVIDAD GINEMATOGRÁFICA EN Colombia. El objeto de la Ley de Cine está en que la producción de películas en nuestro país, lejos de ser una labor apartada, se convierta gradualmente en una industria bien rentable y sostenible; establece así el concepto de industria cinematográfica, entendida como momentos y/o actividades de producción de bienes y servicios de tal naturaleza; en especial los de producción, distribución o comercialización y exhibición. Menciona la definición de sala de cine o sala de exhibición, exhibidor, distribuidor, así como agentes o sectores de la industria cinematográfica.

Ordena al Ministerio de Cultura como rector de la actividad cinematográfica, a través de la Dirección de Cinematografía. Establece una contribución parafiscal denominada "Cuota para el Desarrollo Cinematográfico", a cargo de los exhibidores cinematográficos, los distribuidores y los productores; crea diferentes organismos, tales como el Fondo para el Desarrollo Cinematográfico -cuenta especial sin personería jurídica administrada por el Fondo Mixto de Promoción Cinematográfica-, y la Dirección del Fondo para el Desarrollo Cinematográfico a cargo del Consejo Nacional de las Artes y de la Cultura en Cinematografía, y cuya composición reglamentará el Gobierno Nacional en forma que garantice la presencia del Ministerio de 
Cultura, de la Dirección de Cinematografía de ese Ministerio y de los sujetos pasivos de la contribución parafiscal. Finalmente, la Ley hace referencia al régimen sancionatorio y el modo de imposición de dichas penas.

DEGRETO 352 DE 2004, DESARROLLO GINEMATOGRÁFICO. El citado decreto regula el lugar y el plazo para el pago de la cuota para el desarrollo cinematográfico, así como las sanciones para casos en que no se realice dicha contribución parafiscal. También, establece la elegibilidad de los proyectos susceptibles de acceder a los recursos del Fondo para el Desarrollo Cinematográfico. Recursos de los que habrá de rendir cuentas al Ministerio de Cultura su administrador.

De otro lado, regula estímulos para la exhibición de cortometrajes colombianos, enunciando las reglas para que catalogue como tal. Se otorgan beneficios tributarios a la producción cinematográfica colombiana en general.

LEY 1556 DE 2012, FOMENTA EL TERRITORIO NAGIONAL GOMO ESGENARIO PARA EL RODAJE DE OBRAS GINEMATOGRÁFIGAS. La norma en comento regula el rodaje de las obras cinematográficas en nuestro país, con el fin de promover la imagen de Colombia de un lado, y de otro desarrollar la industria cinematográfica; parte de la definición de nociones básicas como obra cinematográfica nacional, obra cinematográfica extranjera, servicios cinematográficos y sociedad de servicios cinematográficos. Además de esto, la Ley ordena la creación del Fondo Fúlmico Colombia (FFG) estipulando su conformación, funciones y estructuración de recursos; hace referencia a la administración, ejecución y destinación de los mencionados recursos, creando el Comité Promoción Fúlmica Colombia (CPFC) -órgano directivo del FFC- enumerando sus funciones y previendo su conformación.

Hace énfasis en la contratación y contraprestación, así como el capital mínimo que debe invertirse en una filmación en el territorio nacional para que esta sea autorizada; dicho capital ha de constar de es 1800 SMLMV, los cuales deberán ser administrados mediante fiducia vigilada por la Superintendencia Financiera; establece auditorías externas a los proyectos nacionales, y menciona responsabilidades en caso de improcedencia total o parcial de los pagos de contraprestaciones. Por otra parte, reseña las facilidades en trámites y permisos, así como las visas que se otorgarán a quienes busquen realizar estas actividades. 


\section{Patrimonio cultural.}

LEY 397 DE 1997, PATRIMONIO GULTURAL, ESTÍMULOS Y GREAGIÓN DEL MINISTERIO DE GULTURA. La Ley define a la cultura como "aquel conjunto de rasgos distintivos, espirituales, materiales, intelectuales, emocionales que caracterizan a los grupos humanos y que comprende, más allá de las artes y las letras, modos de vida, derechos humanos, sistemas de valores, tradiciones y creencias"; declara luego que "la cultura, en sus diversas manifestaciones, es el fundamento de la nacionalidad y actividad propia de la sociedad colombiana". Tras prohibir al Estado censura alguna sobre manifestaciones culturales, le encarga la tarea de proteger al español como idioma oficial y a las lenguas de los pueblos originarios.

En cuanto al patrimonio cultural, lo define como aquel "conjunto constituido por todos los bienes y valores culturales que son expresión de la nacionalidad colombiana, tales como la tradición, las costumbres y los hábitos, así como el conjunto de bienes inmateriales y materiales, muebles e inmuebles, que poseen un especial interés histórico, artístico, estético, plástico, arquitectónico, urbano, arqueológico, ambiental, ecológico, lingüístico, sonoro, musical, audiovisual, fílmico, científico, testimonial, documental, literario, bibliográfico museológico, antropológico y las manifestaciones, los productos y las representaciones de la cultura popular". Ordena como política pública la "protección, la conservación, la rehabilitación y la divulgación de dicho patrimonio, con el propósito de que éste sirva de testimonio de la identidad cultural nacional, tanto en el presente como en el futuro"; llama la atención la protección dispuesta del patrimonio arqueológico, entendido como muebles o inmuebles originarios de culturas desaparecidas, o de la época colonial, en especial restos humanos y orgánicos relacionados con ellos.

Dispone sobre el Consejo de Monumentos Nacionales, como organismo principal para con el patrimonio cultural, delegando funciones al respecto en los entes territoriales. Permite a las iglesias y confesiones el derecho de propiedad sobre el patrimonio cultural por ellas creado.

Otorga al Ministerio de Cultura - previo concepto del Consejo de Monumentos Nacionales - la responsabilidad sobre la declaratoria y manejo de los monumentos nacionales, así como de los bienes de interés cultural de carácter nacional; manda reglamentar los regímenes a los cuales están sujetos los 
bienes que corresponden al patrimonio cultural nacional del país. Define el patrimonio bibliográfico y similar, haciendo responsable del mismo a varias entidades, entre las que destacan el Ministerio de Cultura, el Ministerio del Interior y entes territoriales.

Sobre fomento y los estímulos a la creación, a la investigación y a la actividad artística y cultural, esta ley enuncia que serán el Ministerio de Cultura y los entes territoriales los encargados de fomentar las artes en todas sus expresiones; estímulos como becas, talleres, bolsas de trabajos y ferias, para así fortalecer expresiones culturales. Define y protege la labor del creador y gestor culturales, promueve intercambios culturales con otros países, y habilita la financiación de tales actividades; dedica varios artículos a la regulación de expresiones culturales cinematográficas.

Establece esta ley la creación del Ministerio Cultura como organismo rector de la cultura; le ordena formular, coordinar, ejecutar y vigilar la política pública al respecto, a la vez que crea el Consejo Nacional de Cultura y sus similares a nivel territorial. Esta ley fue modificada por la ley 3048 de 1997, la ley 617 del 2000, la ley 666 del 2001, la ley 797 del 2003 y la ley 1185 del 2008.

DEGRETO 763 DE 2009, SISTEMA NAGIONAL DE PATRIMONIO GULTURAL. El citado decreto se encarga de definir el Sistema Nacional de Patrimonio Cultural de la Nación (SNPCN) y su constitución, que a su vez se encuentra bajo la coordinación general del Ministerio de Cultura; además, define cuáles serán las entidades públicas del SNPGN, así como las atribuciones específicas que la ley impone para estas, sin perjuicio de las estipuladas por la Constitución y la Ley 1185 de 2008.

Establece, así, los criterios de valoración para declarar bienes de interés cultural (BIC) asignando a dichos bienes diferentes tipos de valores, como son el estético, el histórico y el simbólico. Enuncia los procedimientos para declarar el BIC, lo mismo que la lista indicativa de candidatos a BIC (LICBIC) y su proceso de inclusión, y aclara la iniciativa para la declaratoria. De igual manera, se refiere al concepto del Consejo de Patrimonio Cultural frente a la declaratoria y aprobación del PEMP (Plan Especial de Manejo y Protección); ordena el principio de coordinación que debe existir entre los niveles nacional, departamental, distrital, municipal o de los territorios indígenas y de las comunidades negras. 
Regula los planes especiales de manejo y protección para bienes inmuebles y muebles, así como la competencia para su formulación, la iniciativa de particulares para formularlos, el procedimiento para su formulación y aprobación, su respectiva implementación, el régimen de transición aplicable, los términos para su formulación y aprobación y la competencia residual.

Reglamenta la intervención a los $\mathrm{BIC}$, con los principios generales que deben observarse para realizar este procedimiento; de igual manera, se encarga de establecer los tipos de obras a realizarse para BIC inmuebles, los tipos de acciones e intervenciones para BIC muebles, la solicitud de autorización, y la obligación de restitución de BIC por demolición no autorizada. (Ministerio de Cultura, s.f.)

Organiza el registro de profesionales para la supervisión de intervenciones de BIC, los principios para la intervención, la contratación -en la que las personas naturales o jurídicas que pretendan hacer algún tipo de intervención en un bien mueble o inmueble declarado como BIC, deberán contratar con profesionales certificados para que ejerzan la supervisión de la ejecución-, los requisitos para la inscripción del registro ante el Ministerio de Cultura o entidades territoriales respecto de bienes muebles e inmuebles. De manera consecuente el decreto permite a las entidades territoriales en todo caso establecer su propio registro de profesionales, siguiendo los requerimientos mínimos previstos en él. Debe en todo caso hacerse la respectiva solicitud de inscripción y presentación de la documentación con la previa verificación de los requisitos, para que finalmente el profesional empiece a formar parte del registro de profesionales para la supervisión de intervención del BIC.

Adicionalmente se preocupa por la enajenación y contratos que se realicen sobre BIC de entidades públicas, aclarando que son inembargables, imprescriptibles e inalienables, siendo necesario que las enajenaciones o préstamos entre entidades públicas que versen sobre estos bienes se lleven a cabo mediante acto administrativo motivado; lo mismo aplicará para la celebración de contratos respecto de las entidades privadas sin ánimo de lucro; sin embargo estos contratos con particulares tendrán como finalidad garantizar lo necesario para la protección, recuperación, conservación, sostenibilidad y divulgación del respectivo BIC, garantizando la integridad del inmueble en el uso que se le destine. 
Regula el patrimonio arqueológico, haciendo remisión a diversas leyes y decretos que conforman la regulación especial referente a este tema, sin dejar de lado la Constitución Política en sus artículos 63 y 72, señalando que las disposiciones del presente decreto serán aplicables a este tipo de patrimonio únicamente cuando de forma expresa lo señale; enuncia además que la única autoridad competente facultada para aplicar el régimen de manejo del patrimonio arqueológico a nivel nacional como territorial, es el Instituto Colombiano de Antropología e Historia ICANH estipulando otras competencias para esta entidad.

Dentro de estas competencias, el ICANH podrá declarar áreas protegidas aquellas en las que existan bienes arqueológicos, sin que esa declaratoria afecte la propiedad del suelo, aunque quede sujeto al Plan de Manejo Arqueológico que apruebe la entidad; las áreas protegidas declaradas o que declare el ICANH serán áreas del territorio nacional, privados o públicos, donde se encuentren bienes muebles o inmuebles que cumplan las características de ser patrimonio arqueológico. Podrá solicitarse tal declaratoria por las entidades territoriales, las comunidades indígenas y comunidades negras, cuando estas áreas se encuentren en su jurisdicción. Sin embargo, como regla general, será el ICANH quien reglamentará las acreditaciones, requisitos documentales y aspectos técnicos para la solicitud de declaratoria de Áreas Arqueológicas Protegidas. Se reglamentan los tipos de intervención sobre este patrimonio.

Prescribe que los Planes de Manejo Arqueológico deben ser incorporados a los Planes de Ordenamiento Territorial de aquellos lugares donde existan áreas Arqueológicas Protegidas; aunado a ello, las entidades territoriales donde existan estas áreas deberán informar a la Oficina de Instrumentos Públicos, con el fin de que se hagan las respectivas anotaciones en los folios de matrícula correspondientes. Permite el cambio de tenencia de los bienes arqueológicos, si se cumplen con los requisitos necesarios para la conservación, manejo, seguridad y divulgación de los bienes arqueológicos. El decomiso material de bienes integrantes del patrimonio arqueológico por falta de registro, que se encuentren en poder de cualquier persona es de 5 años contados a partir de la promulgación de la ley del 12 de marzo de 2008.

De igual manera, se regula el patrimonio de imágenes en movimiento, refiriendo que el Ministerio de cultura podrá reglamentar aspectos de orden 
formal y requisitos de acreditación, pues en lo demás remite a normas especiales; modifica el decreto 352 de 2004 en cuanto a la elegibilidad y aprobación de los proyectos. Menciona la declaración y pago de la contribución parafiscal. Respecto de las obras documentales y de animación refiere que no es necesario que acrediten la presencia de actores colombianos según lo estipulado por el Decreto 358 de 2000, sino que tendrá alternativas fijadas para este efecto; igualmente dice que la duración mínima de los cortometrajes nacionales será de 7 minutos; el Ministerio de Cultura hará seguimiento de las actividades cinematográficas, donde el convenio con particulares que realicen las inspecciones respectivas no podrá exceder de 5 años.

Reglamenta el patrimonio archivístico, diciendo que los archivos en su sentido de patrimonio cultural y las declaratorias de BIC, restricciones PEMP, se regirán por lo previsto en este decreto, o reglamentaciones del Ministerio de Cultura. Establece estímulos para la conservación y mantenimiento de BIC; al igual que las faltas contra el patrimonio cultural.

DEGRETO 2941 DE 2009, PATRIMONIO GUlTURAL INMATERIAL. Prescribe que el patrimonio cultural inmaterial hace parte del Sistema Nacional de Patrimonio Cultural de la Nación; de acuerdo con otras normas nacionales e internacionales, establece como dicho patrimonio

los usos, prácticas, representaciones, expresiones, conocimientos y técnicas, junto con los instrumentos, objetos, artefactos, espacios culturales y naturales que les son inherentes, así como las tradiciones y expresiones orales, incluidas las lenguas, artes del espectáculo, usos sociales, rituales y actos festivos, conocimientos y usos relacionados con la naturaleza y el universo, técnicas artesanales, que las comunidades, los grupos y en algunos casos los individuos reconozcan como parte de su patrimonio cultural.

Advierte que el único patrimonio cultural inmaterial que se tendrá en cuenta será el que sea "compatible con los instrumentos internacionales de derechos humanos."

Utilizará el término comunidad o colectividad a todas las personas que tienen que estén vinculados directa o indirectamente con el patrimonio cultural inmaterial. Dispone que sean las entidades que integran al Sistema Nacional de Patrimonio Cultural las responsables de "fomentar la salvaguardia, sostenibilidad y divulgación del Patrimonio Cultural Inmaterial 
con el propósito de que este sirva como testimonio de la identidad cultural nacional en el presente y en el futuro." Son ellas las encargadas de destinar los recursos para tales fines.

Ordena al CONPES trazar los lineamientos requeridos para las políticas relevantes al patrimonio descrito; prohíbe a los particulares abrogarse la titularidad del patrimonio cultural inmaterial, o afectar los derechos de disfrute del mismo; disfrute que ha de respetarse incluso ante procesos de propiedad intelectual.

Dispone la creación de una Lista Representativa de Patrimonio Cultural Inmaterial nacional - conformada y administrada por el Ministerio de Cultura y el ICANH- y otras a nivel de entidades territoriales; listas integradas por una o varias de las siguientes manifestaciones: lenguas y tradición oral, organización social, conocimiento tradicional sobre la naturaleza y el universo, medicina tradicional, producción tradicional, técnicas y tradiciones asociadas a la fabricación de objetos artesanales, artes populares, actos festivos y lúdicos, eventos religiosos tradicionales de carácter colectivo, conocimientos y técnicas tradicionales asociadas al hábitat, cultura culinaria, y, patrimonio cultural inmaterial asociado a los espacios culturales.

La inclusión en la citada lista requiere la verificación de ciertos criterios de valoración- pertinencia, representatividad, relevancia, etc. ${ }^{-} \mathrm{y}$ su postulación está abierta a cualquier institución, persona natural o jurídica. El decreto prescribe los requisitos y procedimiento para tal inclusión, así como el contenido de la respectiva resolución que la reconozca.

El decreto contempla la salvaguardia del patrimonio enunciado mediante dos acciones principales; de un lado, recursos públicos así destinados por entidades públicas para tal efecto, y de las otras deducciones tributarias efectuadas sobre aportes en efectivo realizados por cualquier contribuyente, siempre que se hagan sobre manifestaciones contenidas en un banco de proyectos conformado por el Ministerio de Cultura.

LEY 1675 de 2013, PATRIMONIO GULTURAL SUMERGIDO. La presente define al Patrimonio Cultural Sumergido como

Todos aquellos bienes producto de la actividad humana, que sean representativos de la cultura que se encuentran permanentemente sumergidos en aguas internas, fluviales y lacustres, en el mar territorial, en la zona contigua, la 
zona económica exclusiva y la plataforma continental e insular, y otras áreas delimitadas por líneas de base.

Hacen parte de este patrimonio los restos orgánicos e inorgánicos, los asentamientos, cementerios y toda evidencia física de grupos humanos desaparecidos, restos humanos, las especies náufragas constituidas por las naves o artefactos navales y su dotación, sus restos o partes, dotaciones o elementos yacentes dentro de estas, cualquiera que sea su naturaleza o estado, y cualquiera sea la causa de la inmersión, hundimiento, naufragio o echazón.

Haciendo referencia a que "no se consideran patrimonio cultural sumergido los bienes hallados que sean producto de hundimientos, naufragios o echazones que no hayan cumplido 100 años a partir de la ocurrencia del hecho, los cuales se regulan por las normas del Código de Comercio y los artículos 710 y concordantes del Código Civil en cuanto a su salvamento, y por las demás normas nacionales e internacionales aplicables.

Tampoco se consideran aquellos bienes hallados en hundimientos, naufragios o echazones que hayan cumplido más de 100 años a partir de su ocurrencia, y que no reúnan las condiciones para ser considerados pertenecientes al patrimonio cultural sumergido"; igualmente habla de los criterios aplicables al mismo, como aquellas actividades que pueden hacerse sobre este, como la exploración, intervención, aprovechamiento económico y preservación.

La Ley ordena su conservación y curaduría, que estará principalmente a cargo del Instituto Colombiano de Antropología e Historia (ICANH) y la Dirección General Marítima (DIMAR), que deben priorizar la conservación y garantizar el menor deterioro posible en el desarrollo de las actividades sobre el patrimonio cultural sumergido; de igual manera y continuando con esta línea, explica asuntos relativos a las autorizaciones y contratos relacionados con este patrimonio, y con las actividades de exploración, intervención y aprovechamiento económico.

Estipula cómo serán los procedimientos contractuales, la administración de los bienes y materiales extraídos, así como el valor del contrato y la remuneración del contratista; de igual manera regula el tema de la publicidad de los dichos procesos, y la iniciativa privada con relación al Ministerio de Cultura.

Por otra parte, hace mención de la destinación presupuestal, las diferencias contractuales, y las competencias de la DIMAR; igualmente establece 
las faltas contra el patrimonio cultural sumergido, adicionando un tercer parágrafo al artículo 15 de la Ley 397 de 1997; haciendo además una modificación al Código Penal, creando el Título VII-A referente a los delitos contra el patrimonio cultural sumergido.

\section{Comentarios y análisis.}

La normatividad estudiada permite llegar a diversas conclusiones; el barrido realizado demuestra una preocupación del legislador -bien primario o bien derivado- por regular asuntos relativos a la cultura, como una constante en los últimos veintidós años. Más allá de la pertinencia y bondad técnica de la norma, lo cierto es que el Estado ha mostrado interés en organizar las actividades culturales de nuestro país. Y por supuesto, el gran protagonista -rector, responsable, supremo director, ordenador del gasto, captador de recursos y ente sancionador- es el Ministerio de Cultura, como tal o por intermedio de alguna de las entidades que de él dependen.

Es evidente la aparición de todo un aparato alrededor de la regulación de actividades culturales; es fácil perderse y confundirse entre la gran cantidad de instituciones habilitadas por las normas estudiadas, bien Institutos, Direcciones, Fondos y Consejos. No sería aventurado predecir posibles conflictos competenciales entre ellos a nivel nacional, sin siquiera entrar a considerar los posibles con entidades territoriales. Sin embargo, - en tercer lugar- es un rasgo evidente la descentralización de la regulación, en cuanto se habilitan mecanismos de participación y dirección, en lo que les compete, a entidades territoriales; las normas asignan competencias incluso a comunidades indígenas y afrocolombianas. En ese orden de ideas - cuarto lugar- las normas demuestran coherencia, por lo menos en teoría, con disposiciones constitucionales que propugnan el multiculturalismo, la educación, y el carácter multiétnico de la nación colombiana.

La regulación de la cultura implica interacción constante del Estado para con los ciudadanos, pero también con posibles donantes y benefactores; en ese sentido, toca constantemente con el sistema fiscal, tributario y aduanero, ofreciendo estímulos para aquellos que colaboren, pero a la vez sanciones para aquellos que atenten contra la cultura, entendida como un todo. Es decir, habilita a los distintos organismos e instituciones para ejecutar las políticas que se les asignan. 


\section{Contexto departamental y municipal}

Una vez determinados algunos elementos esenciales para conocer la normatividad que regula el sector cultural y el sistema nacional de cultura, este aparte se dedicará a revisar algunas políticas departamentales y municipales que sirven de ejemplo y referentes para estructurar la política cultural del departamento de Cundinamarca.

La primera definición que se propone como punto de partida para comprender la política cultural es:

Las políticas culturales son las grandes definiciones que asume el país para orientar los procesos y acciones en el campo cultural, a través de la concertación y la activa participación del Estado, las entidades privadas, las organizaciones de la sociedad civil y los grupos comunitarios, y de esta manera, responder con creatividad a los requerimientos culturales de la sociedad (Ministerio de Cultura, Un Ministerio de Puertas Abiertas, 2008).

Como ejemplos y estudios de caso podemos citar la política cultural de los departamentos de Antioquia, Valle del Cauca, Bolívar y Bogotá. Tal y como lo expresa Moreno (2011) :

Gobiernos regionales como el de Antioquia tienen una gran tradición de definición de políticas y planes culturales y ciudades como Bogotá, Medellín o Cali, entre otras, han hecho valiosos aportes definiendo y ejecutando políticas culturales en diferentes áreas de la cultura. De este modo hay una aproximación regional y de ciudad a las políticas culturales que alimentan la gestión cultural local, pero que son indudables contribuciones a la existencia de las políticas culturales nacionales. En las regiones y en lo local se han producido miradas nuevas de la gestión de la cultura incorporando activamente las realidades locales y barriales, generando innovaciones, articulando creativamente diversos campos de la cultura, incentivando procesos reales de participación y estimulando procesos de recreación social de la memoria. Las políticas culturales nacionales no pueden desconocer la significación de estos aportes a su comprensión y construcción (p. 18.).

\section{Políticas culturales a nivel Departamental}

\section{Antioquia.}

Desde el 2012, según el programa de la gobernación denominado Antioquia la más educada se incluyó las 9 regiones del Departamento para diseñar 
e implementar la política pública cultural. Tal y como lo afirma el Instituto de Cultura y Patrimonio de Antioquia "Los avances y logros del movimiento cultural antioqueño han demostrado como: Educación + Legalidad $=$ Oportunidades, por ello, el Instituto de Cultura y Patrimonio de Antioquia presentará ante la Asamblea Departamental, el proyecto de Ordenanza de adopción de una política pública cultural" (Instituto de Cultura y Patrimonio de Antioquia, 2012).

Con la política cultural de Antioquia se busca:

Propiciar, sostener y mejorar las condiciones para el ejercicio de los derechos culturales de todos y todas; promover la asignación equitativa de recursos a través de convocatorias públicas, garantizar que las oportunidades lleguen a todas las regiones, así como la sostenibilidad de los espacios de participación ciudadana. La creación de esta política cultural responde al llamado de los Consejeros de Cultura y de las comunidades en las 9 regiones del Departamento para que la cultura siga siendo motor de la transformación.

Ejes temáticos de la política pública.

1. Convocatorias públicas: como mecanismo democrático y participativo para la asignación equitativa de recursos.

2. Comunicación pública: como estrategia para posibilitar el ejercicio de los derechos a la información oportuna, al acceso y a la participación en la vida cultural.

3. Sistema de información, gestión del conocimiento y accesibilidad: como herramienta integradora de Tecnologías de la Información y las Comunicaciones -TIC-, que soporta el desarrollo de los procesos artísticos y culturales de cara a la ciudadanía, posibilita el acceso a la información y la participación de los habitantes del Departamento y propicia la gestión del conocimiento artístico y cultural.

4. Articulación y participación ciudadana: como mecanismo para la cohesión social y fundamento de procesos pertinentes y sostenibles en el territorio.

5. Planificación cultural: con el reconocimiento de las herramientas de planificación cultural vigentes, como posibilitadoras de la implementación de la política pública. 


\section{Principios}

1. Diversidad e interculturalidad: la diversidad cultural y la interculturalidad son fundamento del diálogo, el intercambio y el desarrollo de capacidades que alimentan la vida pública y la construcción de una cultura de paz.

2. Equidad: reconocimiento de las condiciones que afectan la capacidad de los habitantes del departamento de Antioquia para acceder y participar en la vida cultural, de sus dinámicas y realidades propias, cimientan el desarrollo equitativo y sostenible en todo el territorio.

3. Transparencia: construcción permanente de relaciones de confianza entre la ciudadanía y el gobierno departamental y municipal, bajo criterios de corresponsabilidad, se construye a partir de la gestión abierta y trasparente de iniciativas artísticas y culturales.

4. Intersectorialidad: articulación de saberes y experiencias de diferentes sectores gubernamentales y no gubernamentales en el planteamiento, implementación y evaluación de acciones para el desarrollo local y regional.

5. Participación: la participación activa de organizaciones y personas en la vida cultural, en tanto afirmación y construcción de la ciudadanía cultural y mecanismo para la cohesión social, fundamentan la generación de procesos pertinentes y sostenibles en el territorio.

6. Planificación: proceso metodológico para la toma de decisiones teniendo en cuenta las diferentes realidades del territorio, como base de la gestión de iniciativas para el fortalecimiento de las artes y la cultura en el departamento de Antioquia.

De la política cultural en Antioquia, vale la pena concluir su enfoque de derechos culturales para el desarrollo, el énfasis transversal consiste en ver que en la medida que los derechos culturales generen oportunidades y por ende desarrollo.

\section{Bogotá Distrito Capital.}

Según la Alcaldía Mayor de Bogotá (2011), la política cultural consolida un trabajo colectivo que la Secretaria Distrital de Cultura, Recreación y 
Deporte ha desarrollado entre el 2012 y el 2014 para la formulación de los lineamientos de los subcampos, procesos y enfoques de la política cultural.

Existe una novedad muy reciente en Bogotá y es la creación del Sistema Distrital de Patrimonio Cultural a través del decreto 070 de 2015 (2015) que resalta lo siguiente:

\begin{abstract}
ARTículo $1^{\circ}$. Creación del Sistema Distrital de Patrimonio Cultural. Créase el Sistema Distrital de Patrimonio Cultural, el cual estará conformado por el conjunto de entidades públicas del nivel distrital que ejercen competencias sobre el patrimonio cultural del Distrito Capital, por los bienes y manifestaciones de este patrimonio, por los bienes de interés cultural y sus propietarios, poseedores, usufructuarios y tenedores, por el conjunto de procesos institucionales y por los derechos y obligaciones de los particulares, articulados entre sí. El Coordinador del Sistema Distrital de Patrimonio Cultural será la Secretaría Distrital de Cultura, Recreación y Deporte para lo cual fijará las políticas generales a las que deberán sujetarse las entidades y personas que integran dicho sistema, en el marco de las competencias establecidas en este Decreto.
\end{abstract}

ARTículo $2^{\circ}$. Objeto. El Sistema Distrital de Patrimonio Cultural tiene por objeto contribuir a la valoración, preservación, salvaguardia, protección, recuperación, conservación, gestión para la sostenibilidad, divulgación y apropiación social del patrimonio cultural de Bogotá D.C., de acuerdo con lo establecido en la Constitución Política de Colombia y las leyes sobre la materia, bajo los principios de descentralización, diversidad, participación, coordinación y autonomía.

ARTíCUlO $3^{\circ}$. Entidades que conforman el Sistema Distrital de Patrimonio Cultural. El Sistema Distrital de Patrimonio Cultural estará conformado así:

a. Secretaría Distrital de Cultura, Recreación y Deporte.

b. Secretaría Distrital de Planeación.

c. Instituto Distrital de Patrimonio Cultural.

d. Consejo Distrital de Patrimonio Cultural.

e. Alcaldías Locales.

f. Mesa de Consejeros Locales de Patrimonio Cultural.

g. Archivo Distrital de Bogotá

Cabe anotar que actualmente, el Distrito Capital, en cabeza de la Secretaría Distrital de Cultura, recreación y Deporte, actualmente impulsa el proceso de reflexión que permita realizar un balance crítico y 
propositivo para la formulación de una nueva carta de políticas culturales que irá del 2016 al 2026. Para dicha Secretaría, la discusión y reestructuración de una Política Cultural, hoy en día, exige una enorme responsabilidad reflexiva. América Latina, contexto en el cual también se inserta el Departamento de Cundinamarca. Se ve se atravesada por procesos y fenómenos que transforman las nociones mismas de democracia y de lo público, en momentos de cambio, incluso frente al Post-Conflicto, que requieren de unas políticas que estén a la altura de los movimientos reales de la actividad cultural.

\section{Estrategia de conservación del patrimonio cultural}

Para el caso de Bogotá, vale la pena resaltar la estrategia sobre el patrimonio cultural que es uno de los lineamientos más fuertes de la política distrital en materia de cultura en la que predominan cuatro aspectos esenciales a tener en cuenta según Jaramillo y Zuleta (2003).

- Definición de políticas y actualización de la legislación.

- Construcción de capacidad institucional y organizacional, incluyendo la descentralización administrativa.

- Participación de la sociedad civil, y de todos los interesados, en apoyo a las tareas de conservación del patrimonio.

- Suministro de información por parte del gobierno.

Toda esta estrategia tiene como objetivo asegurar la sostenibilidad del patrimonio cultural y hacer que asuma un papel importante en el desarrollo no solo de un área específica con valor histórico sino también en general de un país o región, entendido este concepto de desarrollo en su más amplio sentido, como desarrollo económico, humano, social y cultural (Jaramillo \& Zuleta, 2003).

\section{Bolívar.}

En el Plan de Desarrollo del Departamento de Bolívar 2012-2015, se encuentra un acápite titulado Cultura: Eje del desarrollo e identidad, que contiene los principales elementos de la política cultural del departamento con una visión transversal a las demás competencias sectoriales (Gobernación de Bolívar, 2012). Se diseñó un programa titulado: "Fomento, promoción y fortalecimiento de los creadores, gestores e instituciones culturales" el cual tenía como objetivo realizar acciones tendientes al fortalecimiento del 
sistema departamental de cultura, permitiendo que los actores culturales desarrollen sus iniciativas, la ciudadanía tenga acceso a la oferta cultural, y se apropie del patrimonio cultural, a través del fortalecimiento institucional y la infraestructura cultural (Gossaín, 2012).

Este programa cuenta con cinco Subprogramas:

- Fortalecimiento del Sistema Departamental de Cultura. Garantizar espacios de participación y organización institucional que posibiliten el desarrollo cultural y el acceso de los bolivarenses a los bienes y servicios culturales en forma eficiente e incluyente.

- Las Artes al Alcance de Todos. Busca fomentar los procesos de formación artística, participación, circulación y creación cultural en el departamento.

- Patrimonio Cultural Bolivarense. Con este subprograma, se busca conocer, valorar, proteger, salvaguardar y divulgar el Patrimonio Cultural del Departamento de Bolívar.

- Infraestructura Gultural del Departamento. Fortalecer la infraestructura física destinada al sector cultural, garantizando conectividad, los servicios tecnológicos y la creación de Un Centro Cultural para las Artes y las Artesanías de la Región Caribe.

- Bibliotecas al Alcance de Todos. Su finalidad es el Fomentar la Red de 50 bibliotecas, de manera que para el 31 de diciembre de 2015 se hallen dotadas y fortalecidas, localizadas en los Zodes departamentales.

\section{Competencias culturales}

- Apoyar el desarrollo de las redes de información cultural, el acceso a los bienes y servicios que prestan las instituciones culturales (redes de casas de la cultura, de bibliotecas, de museos de archivos), la formación artística y las prácticas musicales colectivas: bandas, coros, música tradicional y cuerdas.

- Coordinar entre los municipios acciones orientadas a desarrollar actividades que permitan fomentar las artes en todas sus expresiones y las demás manifestaciones simbólicas expresivas. 
- Impulsar la lectura y la escritura y facilitar la circulación y acceso a la información y el conocimiento.

\section{Gundinamarca.}

A nivel departamental se cuenta con muy pocas fuentes documentales que permitan hacer una reseña del desarrollo de las políticas culturales en Cundinamarca, solo pudiendo remitirse básicamente a lo señalado en los planes de desarrollo de las últimas administraciones departamentales. En el Plan de desarrollo 1998 - 2000 correspondiente a la primera administración de Andrés González, encontramos que en lo que respecta al sector cultural se hace énfasis en la diversidad cultural y el lugar de la cultura en la convivencia. En este se incluía la creación de Dirección de cultura y turismo, cuyo objetivo en el campo cultural sería la preservación, recuperación, difusión y desarrollo económico de la identidad cultural. En la primera Administración Departamental de Álvaro Cruz Vargas, en el Plan de desarrollo en lo que respecta al sector cultural, se enfocaba en el fortalecimiento de la identidad étnica y cultural; teniendo dentro de sus estrategias el apoyo, fomento y financiación a las experiencias y manifestaciones culturales; así como apoyar los procesos de formación artística y cultural dentro del propósito de contribuir a construir un sentido de identidad (Municipio de Facatativá, 2015, p. 13).

En el plan de desarrollo 2004-2007, denominado "Cundinamarca es tiempo de crecer" y correspondiente a la Administración de Pablo Ardila, en el sector cultural se apuntaba al desarrollo de valores y expresiones artísticas y culturales para potenciar la identidad cundinamarquesa. En una de las líneas de acción se apuntaba a la formulación adopción y aplicación del plan estratégico decenal de cultura, sin embargo no se encuentran evidencias de avance en este proceso. En el Plan de Desarrollo 2008 -2001 correspondiente a la segunda administración de Andrés Gonzales denominado "Cundinamarca Corazón de Colombia" se daba un mayor énfasis en la cultura con relación al plan anterior; encaminado el quehacer cultural hacia la promoción y fortalecimiento de los procesos de construcción de identidad. En este plan nuevamente se incluye la formulación del Plan departamental de cultura, planteando que este debe tener un enfoque participativo y de derechos; sin embargo al igual que lo sucedido con la Administración anterior, no se han podido recopilar evidencias que indiquen un avance en este proceso. Finalmente en cuanto al actual Plan de desarrollo 2012-2015 deno- 
minado "Cundinamarca Calidad de Vida" y correspondiente a la segunda administración del Álvaro Cruz Vargas, se encuentra el programa "Cultura, apropiación y cohesión social para la identidad cundinamarquesa" el cual le apunta a "desarrollar una cultura de apropiación del territorio cundinamarqués", teniendo dentro de sus principales líneas de acción el fortalecimiento de las escuelas de formación artística, el fortalecimiento de la Red de Bibliotecas y el fortalecimiento de la identidad a partir del patrimonio (Municipio de Facatativá, 2015, p. 13).

En cuanto a la institucionalidad cultural, se encuentra que en el año 2008 mediante ordenanza 00264 del 15 de octubre de 2008 se crea el Instituto Departamental de Cultura y Turismo de Cundinamarca (IDECUT), teniendo como labor principal el fortalecimiento de las políticas culturales y turísticas del departamento. Se puede concluir que a lo largo de las Administraciones Departamentales que se han mencionado, la acción de la gobernación en favor del desarrollo cultural se ha centrado principalmente en los siguientes procesos: Apoyo a escuelas de formación artística, fortalecimiento de la Red de Bibliotecas, apoyo a eventos artísticos y culturales y fortalecimiento del programa vigías del patrimonio (Municipio de Facatativá, 2015).

En el año 2014 el Ministerio de Cultura a través de la Dirección de Fomento Regional, realizó un análisis situacional del Departamento de Cundinamarca; el cual incluyó todo un referente de cobertura, y alcances desde el plan departamental de desarrollo acoplado a las necesidades que requiere cada uno de los municipios que visitaron. Resultado de ese análisis, se tiene una descripción del contexto departamental:

Las expresiones y manifestaciones culturales en el departamento, por su contexto multicultural, son diversas puesto que en Cundinamarca convergen distintos grupos poblacionales y étnicos en espacios rurales y urbanos. Entre las principales fiestas patronales y festivales representativos, se cuentan el festival del torbellino que se realiza anualmente en el municipio de Tabio, aportando al reconocimiento y revitalización de los bailes, junto con las prácticas y manifestaciones de la cultura inmaterial propias del altiplano cundiboyacense. La celebración religiosa y cultural del Corpus Cristi interpreta los diferentes rasgos y tradiciones de la región, junto con actividades que sirven de preámbulo a la construcción de los arcos que serán adornados con las frutas cosechadas durante el año (Ministerio de Cultura, 2014). 


\section{Contexto sectorial de la cultura en Cundinamarca}

La cultura en Cundinamarca se encuentra distribuida en varios sectores, cada uno de ellos atiende las necesidades y particularidades de cada uno de los municipios y procura extender sus recursos a cada uno de ellos. La cultura en el departamento se financia por medio de la estampilla procultura que en ocasiones y constantemente no es suficiente para las necesidades que cada municipio presenta.

\section{Patrimonio}

Dentro del sector patrimonio se encuentran varios subsectores a los cuales se atiende en su totalidad, a saber: Material, inmaterial, mueble, inmueble, entidades museales, parques naturales, parques arqueológicos y vigías del patrimonio. Actualmente se intenta levantar los indicadores de existencia de cada uno de los subsectores que integran este sector, por particularidad se tiene que los museos y parques naturales se están integrando. Como patrimonio inmaterial se entiende lo que corresponde a una identidad por el lugar, las vivencias, gastronomía, artesanías, conocimientos, carnavales, eventos tradicionales, medicina natural. Para este subsector existe una lista representativa de patrimonio, actualmente el primer intento de esta lista fue la declaratoria por medio de ordenanza para establecer la Garulla de Soacha como patrimonio del departamento.

Por otro lado el plan de desarrollo manifestó unas metas para el rescate del patrimonio se han manejado con dos proyectos:

- Mejoramientos y restauración de bienes de patrimonio: recursos que se deben dedicar a la restauración. Recursos de obra.

- Investigación e inventario del patrimonio: identificación del patrimonio. Identificación de cuáles son los bienes que se deben rescatar y proteger, planes especiales de salvaguarda.

El programa de vigías que se incorpora en este subsector es un voluntariado que impulsa la protección y conocimiento del patrimonio existente en cada uno de los municipios. Otra particularidad que tiene este subsector es que no hay una batería de indicadores sobre los bienes patrimoniales, hay una cierta cantidad de patrimonio sin identificar en los municipios y lo inmaterial aún no se ha detallado con especificidad. 
En concordancia con las políticas nacionales, se tiene por registro que el museo nacional publicó su política nacional de museos la cual debe articularse con las necesidades del departamento. En la actualidad, se insta a las comunidades étnicas, a articularse al trabajo que se desarrolla desde el Ministerio de Cultura, el IDECUT y los Municipios. Adicionalmente hay comunidades ROM asentadas en el departamento, se carece de la información básica demográfica. Junto a ellos, y en la diversidad cultural que se hallan en el departamento, están las comunidades afro descendientes. Las decisiones respecto de este subsector son tomadas en el Consejo Departamental de Patrimonio.

\section{Música}

Dentro del sector música se atiende a varios subsectores que se presentan en el departamento de Cundinamarca: Bandas, coros, música tradicional y cultural y orquestas. El departamento cuenta con el coro Orfeón y con la banda sinfónica y tienen contratación directa con el IDECUT por ordenanza desde hace 40 años, adicionalmente las bandas municipales son apoyadas por el IDECUT pero cada una de ellas se encuentran en los municipios, a la fecha se encuentran 54 coros inscritos categorizados de la siguiente manera: a) Infantil, b) juvenil, c) adulto y d) adulto mayor. De igual manera, hay 12 orquestas en el departamento. Para las bandas se maneja el componente de dotación de instrumentos musicales, por cantidad de recursos no es fácil dotarlas a todas. Se adelantan procesos de clasificación y selección en los encuentros municipales que se organizan, atendiendo desde la iniciación musical hasta las bandas.

El proceso se desarrolla de la siguiente manera:

- Iniciación musical en primera infancia que va desde los 0 hasta los 5 años de edad.

- Prebandas y bandas infantiles que va desde los 6 años hasta los 11 años de edad.

- Bandas adolescentes desde los 12 a los 18 años.

- Bandas juveniles desde los 18 a los 28 años.

- Bandas de mayores o formato libre.

- Banda sinfónica especial con instrumentación más grande, las cuales son 4 Tocancipá, Chía, Mosquera y Funza. 
Banda fiestera o tradicional popular con instrumentos más folclóricos que es la principal en los municipios.

Desde el IDECUT se ha gestionado la capacitación de docentes por medio de diplomado, existe el seminario capacitación para no músicos para fortalecer el proceso de aprendizaje y cobertura. Se ha realizado un programa de música para madres gestantes, estimulación temprana. En este sector de la cultura no se incluyen las bandas músico marciales.

Las bandas y los grupos participan en los encuentros organizados por los municipios en concordancia con el IDECUT; de igual manera hay encuentros departamentales a los cuales asisten y una vez terminado el encuentro se levanta un acta donde se premia a las bandas y se da vía libre para participación en eventos nacionales. Actualmente existen en el departamento 90 agrupaciones de música popular y música andina latinoamericana.

\section{Bibliotecas}

El departamento cuenta con 143 bibliotecas, las cuales se rigen por el plan nacional de bibliotecas públicas del Ministerio de Cultura que en el año 2002 fue donde se formó la red de bibliotecas, para cada municipio hay una biblioteca la cual es creada por acuerdo municipal. Este sector está fortalecido puesto que cuenta con 4 nodos regionales que atienden a los116 municipios del departamento, cada nodo cuenta con un coordinador regional. No hay un registro de frecuencia o de ingreso de la sociedad a las bibliotecas en tanto que son públicas, lo que no permite llevar dicho registro. Cada año se adelantan los procesos de dotación Asimismo, a las bibliotecas en consecución con el Ministerio de Cultura y el IDECUT. De igual manera hay cierta cantidad de bibliotecas rurales, las cuales funcionan al interior de instituciones educativas lo que hace que sean manejadas por las administraciones de turno.

Cada uno de los municipios se debe encargar de la infraestructura de las bibliotecas y de mantener una persona en el cargo de encargado de la biblioteca, es el Ministerio quien en este caso asume el internet y ayudas web para las bibliotecas. Para el departamento la función es de proveer apoyo técnico e insumos de material bibliográfico junto con recursos tecnológicos. El IDECUT adelanta procesos de formación y capacitación para las personas encargadas puesto que la mayoría de las personas a cargo no tienen la 
formación específica, la clasificación de las bibliotecas depende de su capacidad, tamaño y servicios que ofrece; entre las que cuentan con un alto grado de calidad son las de Funza, Mosquera y Zipaquirá. La red de bibliotecas ha avanzado en el sentido que es más articulada pero desde lo local hace falta compromiso; por lo que es necesario que las administraciones entiendan la importancia de la biblioteca.

Respecto de los recursos son limitados, la red de bibliotecas es grande y algunas bibliotecas nos son sostenibles, aludiendo al tema de la catalogación hay un software que va dentro de la dotación suministrada pero presenta fallas, se avería con facilidad y no cumple su función, de igual manera se presenta que no hay un relacionamiento de las bibliotecas públicas con la secretaría de educación.

\section{Escuelas de formación artística y cultural, teatro y danza}

Este sector atiende a toda la población, el objetivo radica en el aprovechamiento del tiempo libre, las jornadas de trabajo con la población es extracurricular, permitiendo el buen aprovechamiento. Es uno de los sectores que más población atiende, para el año 2014 asistieron más de 17000 personas en las escuelas de formación, para el 2015 se tienen 100 convenios con los municipios en varias modalidades: danzas, artes plásticas, música, teatro, literatura y coros. En la actualidad se adelantan los zonales de teatro para medir el nivel y la calidad de las escuelas de formación en teatro y danza, luego se realizará el evento departamental. No se cuentan con los espacios adecuados para la ejecución de las clases, de igual manera como se presenta en los anteriores subsectores se hacen falta recursos para aportar y apoyar a las escuelas.

\section{Valle del Cauca.}

La Gobernación del Valle 2001-2010 plantea que:

La Política Cultural tiene una importancia primordial en el desarrollo económico, social y político de la región, pues la cultura conformada por las creencias y formas de vida, en una sociedad específica, condiciona y a la vez explica tanto los éxitos (desarrollos) como los fracasos (crisis) de dicha sociedad: de ahí que las características específicas de las culturas locales aporten en gran medida a que las políticas de desarrollo que se impulsan tengan éxito o fracaso al aplicarse. Símbolos, creencias, formas de ser, pensar y hacer las cosas según 
el sentir de la -comunidad, facilitan u obstaculizan que las variables económicas (productividad, efectividad, calidad, cumplimiento, competitividad), las variables sociales inclusión, transparencia, respeto, convivencia y solidaridad) y las de desarrollo político (democracia, participación, descentralización, autonomía) se dinamicen o se estanquen (2010).

El objetivo de la política Departamental del Valle del Cauca es:

Fortalecer la cultura local y regional mediante el fomento de la democracia y la participación ciudadana en la promoción de principios, valores, y hábitos de vida, así como la creación y disfrute de las diferentes expresiones estéticas para estimular el diálogo entre las diferentes manifestaciones culturales tanto locales como externas, y responder así al reto cultural actual de propiciar la interacción pertinente entre lo local y regional con los fenómenos de globalización, interdependencia y multiculturalidad, todo lo cual se traducirá así en aportes culturales fundamentales para el desarrollo integral de la región y sus ciudades, pueblos, barrios, corregimientos y veredas (Gobernación del Valle, 2010).

\section{Características de la política}

Las Políticas Culturales de Valle del Cauca están regidas por una concepción de desarrollo cultural y otorga toda la responsabilidad sobre la cultura a la sociedad, donde el Estado propicia las instituciones, los espacios y las instancias pertinentes, configurando una política cultural de apoyo oficial, descentralizada, participativa, dialógica y de trascendencia tal y como lo plantea la Gobernación de Valle del Cauca (2010):

1. Política Descentralizada y Participativa. Una primera característica de la política cultural es su carácter democrático, descentralizado y participativo, donde la sociedad se ocupa directamente de la cultura como un derecho consagrado en la Carta de los Derechos Humanos promulgada por las Naciones Unidas en la Constitución Colombiana y en la Ley_ General de Cultura.

2. Política de Apoyo Oficial. El segundo elemento de la política es la intervención estatal; cómo dialogan la sociedad civil y el Estado, construyendo el sentido y el hacer · cultural de la región. Es una obligación del Estado, la promoción de la cultura, mandato que recibe de la Constitución y la Ley, que le asigna la función de ser el principal promotor del desarrollo cultural, para que facilite el acceso de 
ciudadanas y ciudadanos a los bienes y contenidos de la cultura. Se requiere que el Estado se comprometa a gestionar acciones concretas que impulsen, favorezcan, apoyen, fortalezcan y faciliten a las comunidades rurales y urbanas, el desarrollo de proyectos culturales diseñados y realizados por ellas mismas a partir de sus propias experiencias, conocimientos y aspiraciones.

3. Política de Trascendencia. La Política Cultural promueve y apoya los procesos que ponen a los vallecaucanos en contacto consigo mismos y con otras culturas, la sostenibilidad de esta riqueza, que es la diversidad, sólo es garantizable mediante el fortalecimiento de procesos de reconocimiento, asimilación y transformación de los productos culturales endógenos y exógenos que nos permita trascender en el mundo como vallecaucanos.

4. Política de Diálogo. Dada la enorme diversidad cultural regional, producto de una gran multiplicidad y pluralidad étnica hay una estrategia de acercamiento para negociar, intercambiar y propiciar diálogos entre diferentes etnias. La política de diálogo permite establecer la comunicación entre las diversidades de lo artístico y lo cultural, facilitando el conocemos y reconocemos e involucramos a la sociedad civil) a empresa privada, el gobierno y los medios de comunicación para que conversen y construyan desde la diferencia.

\section{Variables frecuentes en los departamentos referentes.}

De acuerdo a cada uno de los departamentos anteriormente mencionados e identificados como referentes exitosos en el tema cultural, se encuentra que las variables exitosas en la gestión cultural de los mismos son:

- Diversidad e interculturalidad: la diversidad cultural y la interculturalidad son fundamento del diálogo, el intercambio y el desarrollo de capacidades que alimentan la vida pública y la construcción de una cultura de paz.

- Intersectorialidad: articulación de saberes y experiencias de diferentes sectores gubernamentales y no gubernamentales en el planteamiento, implementación y evaluación de acciones para el desarrollo local y regional 
- Dada la enorme diversidad cultural regional, producto de una gran multiplicidad y pluralidad étnica hay una estrategia de acercamiento para negociar, intercambiar y propiciar diálogos entre diferentes etnias.

- La política de diálogo permite establecer la comunicación entre las diversidades de lo artístico y lo cultural, facilitando el conocemos y reconocemos e involucramos a la sociedad civil) a empresa privada, el gobierno y los medios de comunicación para que conversen y construyan desde la diferencia.

- Apoyar el desarrollo de las redes de información cultural, el acceso a los bienes y servicios que prestan las instituciones culturales (redes de casas de la cultura, de bibliotecas, de museos de archivos), la formación artística y las prácticas musicales colectivas: bandas, coros, música tradicional y cuerdas.

\section{Políticas culturales en algunos Municipios de Cundinamarca}

\section{Chía.}

El municipio de Chía presenta desde la Secretaría de Desarrollo Social y la Dirección de Cultura el Plan decenal de cultura 2015-2024, tres fases hacen parte de este plan, a saber: Diagnóstico, Concertación e Institucionalización. Dentro de la fase diagnóstico la Secretaría de Cultura revisó la documentación pertinente, aplicó entrevistas y encuestas personalizadas y vincularon a más de diez mil personas. En la fase de concertación se realizaron mesas de trabajo, información que se validó en el Consejo Municipal de Cultura, de igual manera realizó una jornada de socialización y validación externa. Y finalmente en la fase de institucionalización se tuvo como resultado el debate y la aprobación de dicho plan por acuerdo municipal número 83 de 2015. La estructura del plan decenal de cultura del municipio de Chía en su visión general presenta visión, principios y objetivos, a través de la interculturalidad, creatividad, concertación, articulación intersectorial, sostenibilidad y empoderamiento se abren paso cinco importantes temas, a saber: enfoques, líneas de acción, sostenibilidad, monitoreo y evaluación, y la región capital.

Los enfoques del plan son tres, participación, apropiación y territorio. Las líneas de acción son la dinamización del sistema municipal de cultura, 
el fomento a las prácticas artísticas, la comunicación y cultura digital, la infraestructura cultural, el patrimonio cultural, la diversidad y diálogo intercultural, el emprendimiento cultural y el fortalecimiento de las prácticas lectoras y escritoras.

La sostenibilidad del plan depende de temas administrativos, sociales y económicos.

Y finalmente para hacer de este plan una política perfectible realizan planes operativos anuales como monitoreo y evaluación de la ejecución del plan decenal.

Para cada uno de las líneas de acción determinan cierta cantidad de programas, estrategias, metas e indicadores.

\section{Chocontá.}

El objetivo del Plan de Acción Municipio de Chocontá es

Mejorar la calidad de vida de los habitantes del Municipio y de manera prioritaria de la población en situación de vulnerabilidad, garantizando el acceso a la oferta de servicios en condiciones de calidad y oportunidad, que permita reducir los niveles de pobreza, exclusión e inequidad social, promoviendo en el Municipio una cultura de bienestar que vincule al total de la población en la construcción de una vida digna y un futuro mejor para las generaciones presentes y futuras (2015).

Los principales proyectos del plan de acción para la cultura en Chocontá son: mantenimiento y dotación de biblioteca; formación, capacitación e investigación artística y cultural; pago de instructores y bibliotecólogos contratados para la ejecución de programas y proyectos artísticos y culturales; pago de instructores contratados para las bandas musicales; fomento ,apoyo y difusión de eventos y expresiones artísticas y culturales; construcción, mantenimiento y adecuación d la infraestructura artística y cultural; protección del patrimonio cultural; promoción del desarrollo turístico; y fortalecimiento institucional.

\section{Facatativá.}

La Política Municipal de Cultura, ante todo reconoce a todos los facatativeños y facatativeñas como protagonistas, preservadores y creadores de la cultura; partiendo de una concepción amplia de esta, entendiendo que de la 
cultura hacen parte los imaginarios, rasgos, creencias, tradiciones, formas de ser y expresiones que le son comunes a un pueblo y a partir de los cuales se genera un sentido de unidad e identidad, donde las manifestaciones estético expresivas se configuran en un medio privilegiado de la manifestación cultural, como exteriorización de lo simbólico y lo trascendental (Municipio de Facatativá, 2015, p. 28). La cultura es un proceso dinámico y diverso que se suscita a partir del dialogo y la convivencia social, es un encuentro de singularidades y particularidades, de formas de ser, sentir, pensar y actuar de diversos grupos sociales a quienes los unen de una u otra forma diferentes tipos de vínculos; en la que desde la diversidad se construye un sentido de comunidad e identidad, vivenciado y arraigado en la cotidianidad, y en donde todos y todas participamos de una u otra forma de la creación y la acción cultural.

La política cultural de Facatativá le debe apuntar:

A potenciar, fortalecer y enriquecer los diferentes elementos culturales de la comunidad, dándole una connotación de política pública, donde la ciudadanía plantea, orienta, decide y vivencia el itinerario de su desarrollo cultural como grupo humano, generando una democracia cultural; en donde el que hacer de la gestión pública está encaminado a asumir un papel de promotor, facilitador y garante del ejercicio y goce por parte de la ciudadanía de sus derechos culturales. Por tanto la cultura es parte de las comunidades y su propiedad reside en ellas, no en pequeñas elites que la comparten de forma "generosa" con sectores populares.

La política cultural del municipio de Facatativá cuenta con 5 líneas estratégicas:

ARTES: Las artes son la manifestación sensible, reflexiva, critica, ética y estética de los individuos que surge al interior de la cultura como producto de un contexto espacio temporal en relación con lo local y que se inserta en procesos de universal; estando mediada por las dinámicas existentes entre lo tradicional y lo contemporáneo. Es desde la visión particular del artista que se, transforman, crean y recrean la realidad en productos estéticos y artísticos que difieren de lo mercantil para enriquecer el panorama cultural y la identidad. (Municipio de Facatativá, 2015, p. 28).

PROMOCIÓN $Y$ DIFUSIÓN CULTURAL: La promoción y difusión cultural, desde el enfoque de Democracia Cultural, busca reconocer, afianzar, fortalecer, transmitir, compartir y divulgar las diferentes expresiones culturales de una comunidad y a su vez suscitar el encuentro de esta con otras mani- 
festaciones culturales, generando un fortalecimiento y aprecio de lo propio, así como un enriquecimiento mutuo; con lo cual se logra una vivificación y dinamización de la cultura. Promover y difundir la cultura, es suscitar la valoración de la cultura propia y estimular la apertura al conocimiento de otras culturas. (Municipio de Facatativá, 2015, p. 31).

PATRIMONIO CULTURAL: El Patrimonio Cultural es el legado material e inmaterial, que las generaciones anteriores le han dejado a un pueblo a partir del cual se constituye la identidad de este como colectivo social; así como la corrientes contemporáneas que alcanzan un arraigo en el imaginario colectivo y logrando una incidencia real que permanece a través del tiempo, y que a su vez se transmite como herencia a las generaciones futuras. El Patrimonio Cultural está compuesto por usos, costumbres tradiciones, expresiones artísticas, elementos de carácter histórico y arqueológico, y en general aquellos bienes inmateriales y materiales que poseen una significación relevante para determinado pueblo. (Municipio de Facatativá, 2015, p. 33).

IDENTIDAD Y DIVERSIDAD CULTURAL: La identidad cultural de un pueblo se construye a partir de aquellos elementos comunes en el imaginario cultural y la vivencia cotidiana de una comunidad, como valores, tradiciones, símbolos, creencias, actitudes sociales y formas de comportamiento, que con el transcurso del tiempo se han transmitido a través de las generaciones, constituyéndose en elemento catalizador del auto reconocimiento como colectivo, el sentido de pertenencia y la unidad de determinado grupo social; configurando de esta forma una identidad cultural (Municipio de Facatativá, 2015, p. 34).

CULTURA CIUDADANA: Se asume como Cultura Ciudadana, el conjunto de Principios, valores, actitudes, costumbres y reglas compartidas por un grupo humano, sobre los cuales se cimienta la convivencia en comunidad. La Cultura Ciudadana se configura pues en un acuerdo o pacto social, en donde todos y todas, asumen la corresponsabilidad social en la generación del bienestar comunitario, de una manera consiente, autónoma y comprometida (Municipio de Facatativá, 2015, p. 35)

GESTIÓN CULTURAL: La Gestión Cultural está encaminada a promover el desarrollo cultural y a generar las condiciones que posibiliten este. Desde el enfoque de Democracia Cultural, la gestión cultural ha de encaminarse a suscitar un substrato favorable para el reconocimiento, valoración y proyección de los diferentes elementos culturales de una comunidad y el enriquecimiento de estos por medio del encuentro e interacción con otras culturas (Municipio de Facatativá, 2015, p. 36). 


\section{Girardot.}

El origen de la política cultural en el Municipio de Girardot 2012-2015 se establece al concebir que la cultura hoy en día debe ser reconocida como de desarrollo social y territorial de una comunidad, ya que son los mismos ciudadanos quienes en sus propios contextos construyen su imagen e identidad, la cual proyecta y refleja sus intenciones, fortalezas y oportunidades de progreso. Por esto, al realizar una indagación sobre el estado del Sector Cultura en Girardot, se halló que el ente territorial durante los últimos 4 años adelantó una importante gestión lo que conllevó al fortalecimiento del mismo a través de la Creación y Desarrollo de los Talleres de Formación Artística en Teatro, Danza y Folclor, Instrumentos de Vientos, Tuna, Pre Banda Sinfónica, Instrumentos de Percusión, Semillero de Danzas, Instrumentos de Teclado, Técnica Vocal y Dibujo, principalmente. Estos dirigidos a la población infantil y juvenil de Girardot, mayoritariamente (Municipio de Girardot, 2011).

Se identifica que mediante gestión administrativa se formalizaron los siguientes Acuerdos y Decretos Municipales: Mediante Decreto No 212 de Junio 11 de 2009 se creó el Consejo Municipal de Cultura; Mediante Acuerdo Municipal No 09 de 2009 se creó la Escuela de Música Banda Sinfónica de Girardot; Mediante Acuerdo Municipal No 020 de 2009 se institucionalizó la Banda Marcial Ciudad de Girardot; Mediante Decreto Municipal N ${ }^{\circ}$ 140 de 2010 se creó la Escuela de Danzas Folclóricas.

Girardot: Artística y cultural (Municipio de Girardot, 2011, p. 210). Reestructurar y consolidar las Escuelas de Formación Artística y Gultural en Girardot como espacios promotores del desarrollo integral de los girardoteños, y como acompañantes del proceso de educación formal a niñas, niños, adolescentes y jóvenes principalmente, fortaleciendo su identidad y propiciando el reconocimiento a la diversidad cultural, local, regional y nacional. Formando ciudadanos que participen en la construcción de comunidades cuyas raíces sean la base fundamental de su sentido de pertenencia local. Descubrir potenciales y valores que les estimulen solidaridad, convivencia y respeto por sus entornos y participen decididamente en la construcción de una sociedad más tolerante y un individuo más integral. Fomentar el Arte y la Cultura en todas sus manifestaciones a través de la generación de nuevos espacios que dinamicen los procesos de 
creación artística y cultural en la ciudad con el fin de garantizar derechos y condiciones que permitan y conlleven a la formación de ciudadanos integrales.

Nuestro Patrimonio Hoy, Nuestra Historia Siempre. (Municipio de Girardot, 2011, p. 215). De igual manera, el patrimonio histórico - cultural es el equivalente a aquellos elementos y manifestaciones tangibles o intangibles producidas por la ciudad y su gente constituyéndose como el resultado de un proceso histórico mediante el cual se constituye el fundamento de su identidad. Dentro de ese contexto, para la Alcaldía Municipal de Girardot es importante fundamental rescatar y fortalecer ese proceso histórico con el objetivo de forjar la identidad cultural, la cual debe ser de conocimiento público toda vez que hace parte del patrimonio intangible e invaluable de Girardot, sinónimo de costumbres, pensamientos y estilos de vida que día a día son y serán evidencia de ese legado cultural escrito por la historia de una ciudad y por las acciones de su gente. Es necesario recuperar la institucionalidad histórica y cultural de Girardot mediante la conservación, protección, promoción y apropiación social del Patrimonio Histórico - Cultural como un bien de interés general de participación ciudadana y comunitaria que permite crear identidad y testimonios de nuestras manifestaciones y expresiones culturales con el fin de que se conviertan en la memoria y el legado de la ciudad, generación tras generación.

\section{Variables frecuentes en los municipios referentes.}

- El fortalecimiento de la institucionalidad cultural, mediante el reconocimiento y articulación de experiencias de desarrollo local en el Sistema Nacional de Cultura.

- Todos tienen claro que la sostenibilidad del plan depende de temas administrativos, sociales y económicos

- Fomento ,apoyo y difusión de eventos y expresiones artísticas y culturales

- El plan decenal es una herramienta que determina la ruta a seguir, que invita a la interacción, la sinergia y la suma de esfuerzos conjuntos, donde la participación corresponsable de los agentes del campo es fundamental. 
- Las necesidades de cada municipio deben articularse con las soluciones dadas en los planes decenales.

- El patrimonio cultural se constituye de manera especial en formas de organización social, relaciones entre los diversos sectores de la sociedad y de las instituciones sociales. 


\section{Capítulo 4}

\section{RESULTADOS DEL PROGESO DE INVESTIGAGIÓN}

Como se mencionó en el apartado de descripción 1 metodológica, en el desarrollo de la investigación con el objeto de la consecución y análisis de información de identificación de situaciones consideradas como problemáticas y sus subsecuentes soluciones, a partir de un enfoque interpretativo, se aplicaron dos instrumentos de medición no probabilísticos: encuesta y entrevista semiestructurada. A continuación se presentan los resultados y análisis de aplicación del instrumento de encuesta.

\section{Aspectos demográficos}

Clasificación de la población según rango de edad.

De los 338 instrumentos aplicados, el $30 \%$ de las personas consultadas se encuentran en un rango de edad entre los 26 y los 45 años como se puede observar en la ilustración 1. La mayoría del conjunto interpelado por medio de los instrumentos de medición es considerada como Población Económicamente Activa (PEA) y que por tanto, se encuentra vinculada al sector cultura. 
Ilustración 1. Clasificación de la población con aplicación de instrumentos de medición por edad

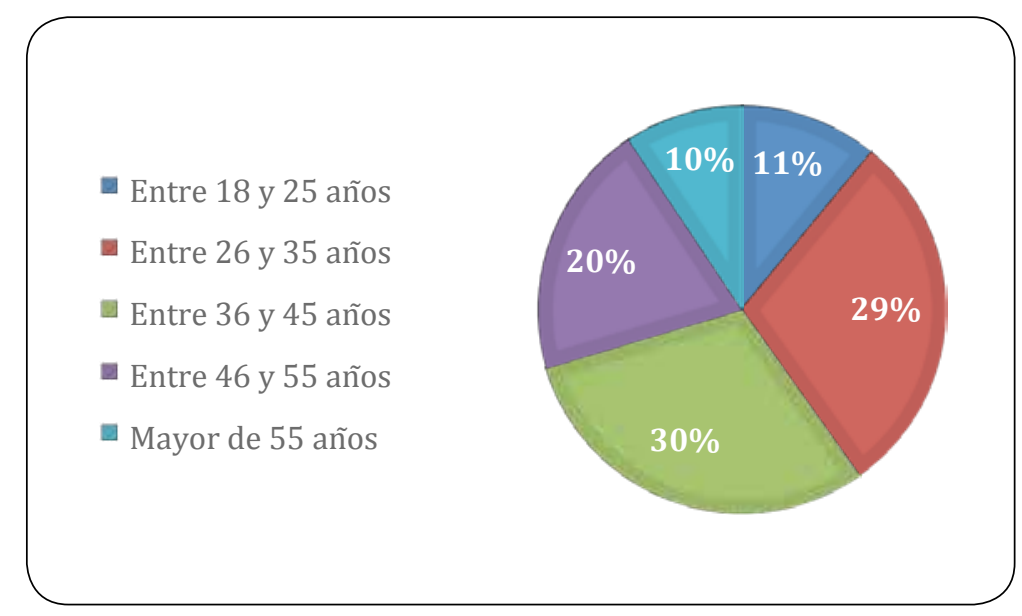

Fuente: elaboración de los autores.

\section{Clasificación de la población según género.}

Desde la perspectiva de género, el $56 \%$ de los actores consultados son hombres y el $44 \%$ mujeres.

Ilustración 2. Clasificación de la población según género

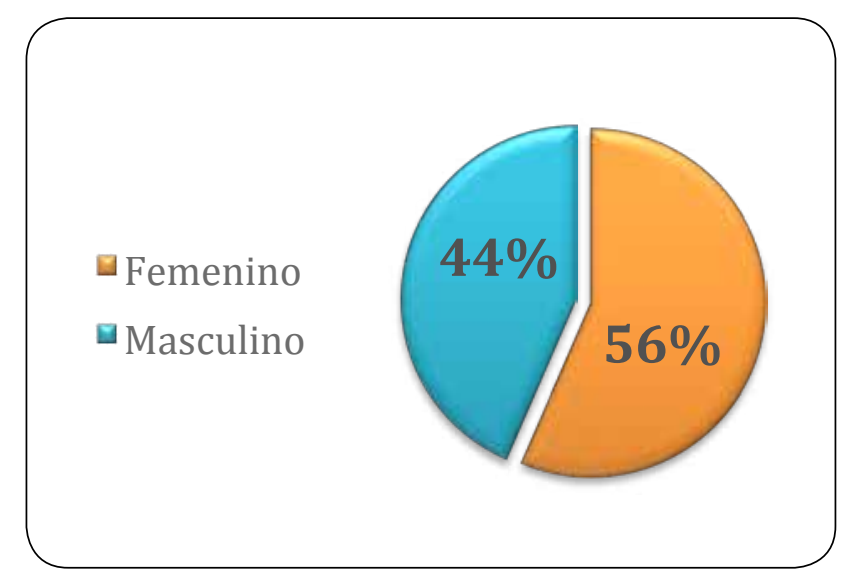

Fuente: elaboración de los autores. 


\section{Clasificación de la población por grado académico.}

De los actores consultados el $41 \%$ declara tener un nivel de formación superior o igual al profesional. Como se podrá observar en el acápite de identificación de problemas, este es una de las problemáticas del sector; el bajo nivel académico y de formación específica.

Ilustración 3. Clasificación de la población por grado académico

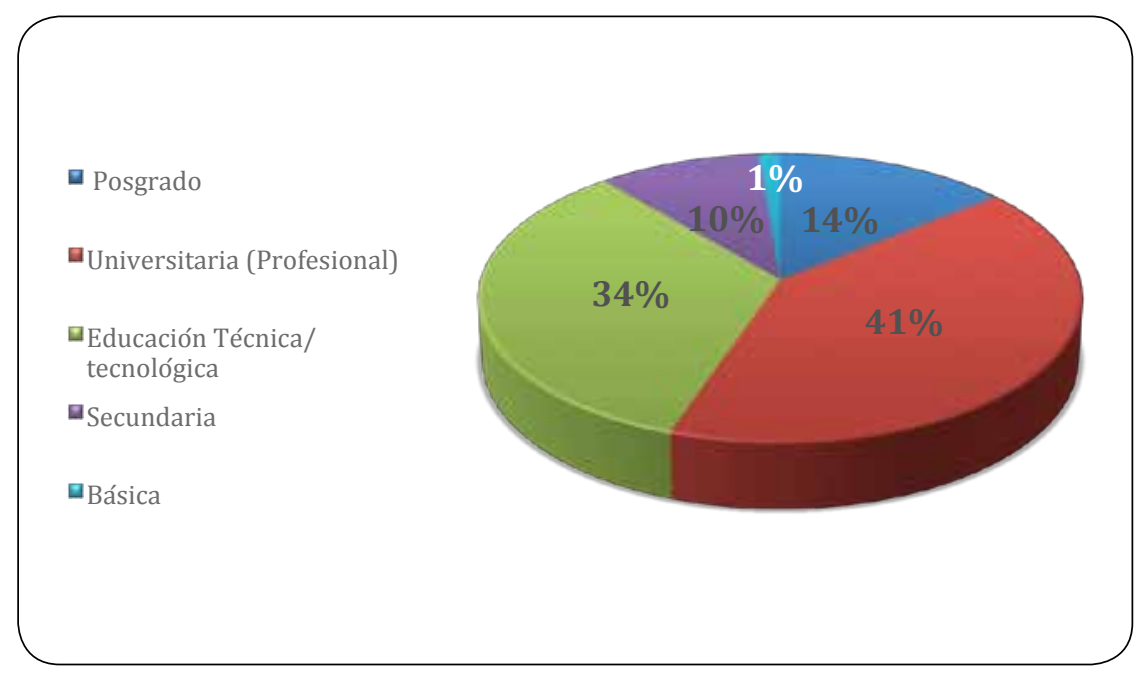

Fuente: elaboración de los autores.

\section{Aspectos temáticos}

\section{Nivel de conocimiento de las políticas nacionales de cultura.}

$\mathrm{Al}$ consultar a los actores que participaron en el proceso consultivo, el 55 $\%$ señala que conoce poco las políticas que tanto desde el orden Nacional como Departamental se han gestado y estructurado sobre la cultura. La variable de conocimiento y divulgación se identifica como otra de las situaciones problemáticas del sector. En contraste el $30 \%$ de los actores consultados manifiestan conocer lo suficiente las políticas, mientras que solamente en $6 \%$ indica que conoce bastante bien el proceso de las políticas públicas de cultura que hay en el país. 
Ilustración 4. Conocimiento de políticas nacionales de cultura

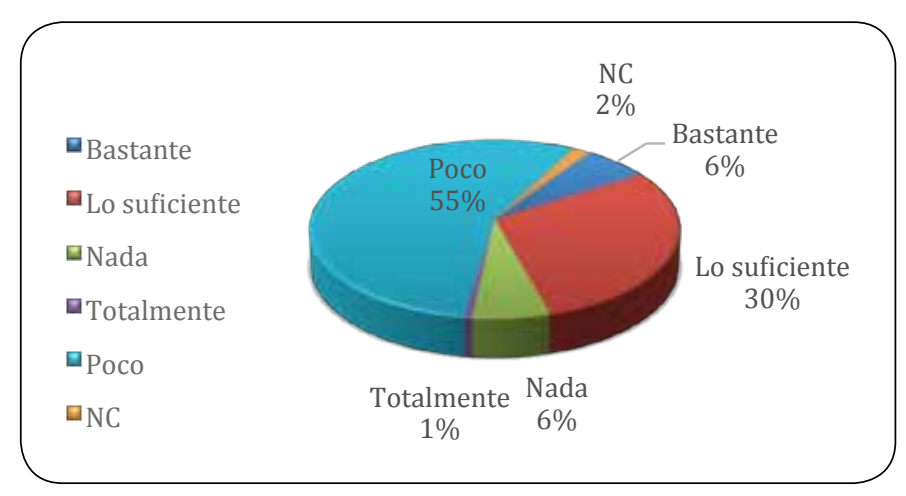

Fuente: elaboración de los autores.

\section{Nivel de consideración de reestructuración de las políticas de cul- tura nacionales.}

El $82 \%$ de los actores encuestados manifiesta que es necesaria una reestructuración de las políticas culturales nacionales. Sin embargo, y en contraste con la anterior pregunta, que hacía referencia al conocimiento de las políticas vigentes, se puede interpretar que existe una percepción desfavorable sobre las políticas pero que esta no está basada sobre el conocimiento de la misma. Nuevamente, se reitera una variable de conocimiento y apropiación social sobre las políticas públicas.

Ilustración 5. Porcentaje de actores que están de acuerdo a la reestructuración de las políticas culturales del país.

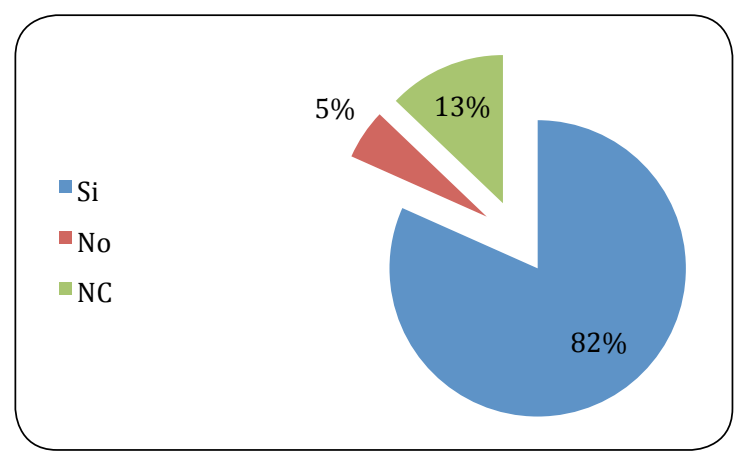

Fuente: elaboración de los autores. 


\section{Acceso a la oferta cultural.}

$\mathrm{Al}$ preguntar a los actores sobre las razones por las cuales la población accede a la oferta cultural el $32 \%$ por el interés y motivación sobre una actividad específica; seguido de un $29 \%$ que argumenta es por disponibilidad de tiempo; y un $19 \%$ asevera que se debe a la cercanía de escenarios e infraestructura cultural.

Ilustración 6. Razones de acceso a la oferta cultural.

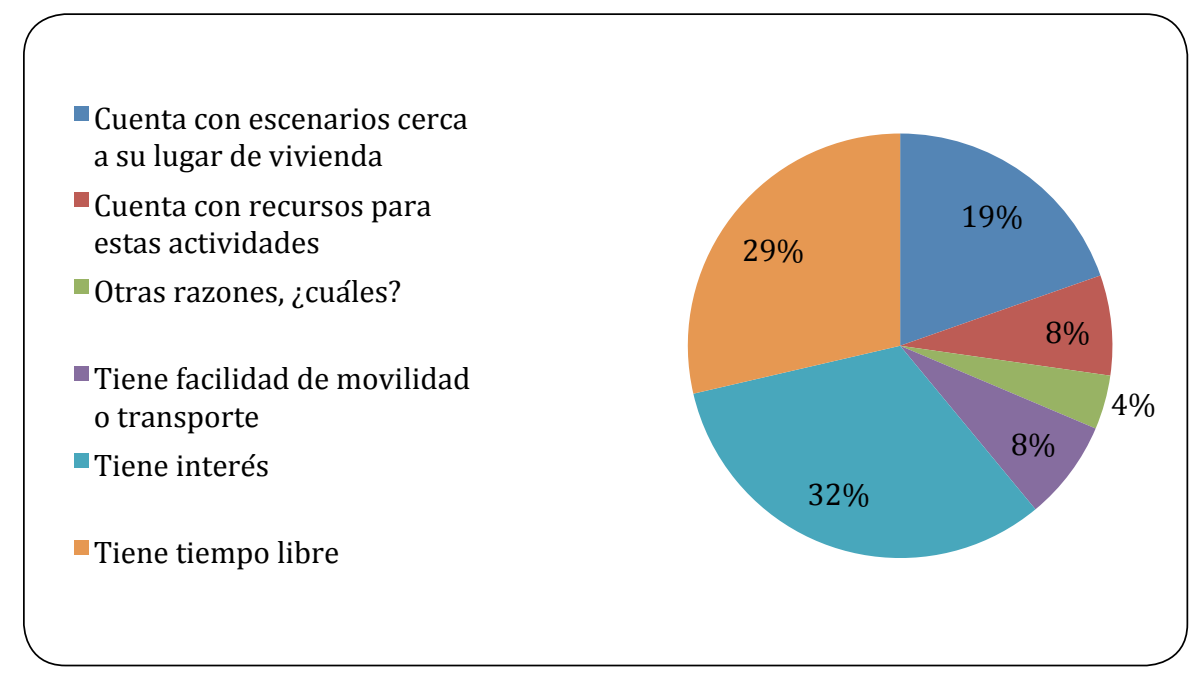

Fuente: elaboración de los autores.

\section{No acceso a la oferta cultural.}

Por su parte, y en relación a la pregunta anterior, al interpelar a los actores sobre las razones por las cuales la ciudadanía no accede a la oferta cultural, la primera de ellas con un $12 \%$ corresponde a la dificultad de movilidad, seguida por una falta de interés con un $11 \%$, y un $10 \%$ en relación a la continuidad de los procesos. En este aspecto, resalta que por distribución estadística de la muestra, no existen factores determinantes, sino que la percepción es que existe un conjunto multicausal. 
Ilustración 7. Razones de no acceso a la oferta cultural.

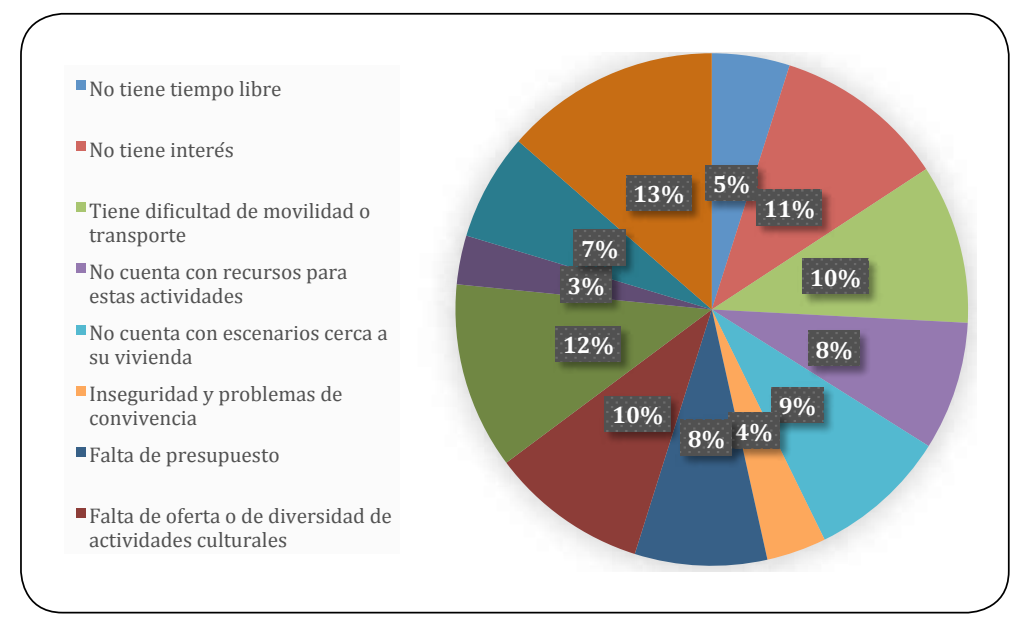

Fuente: elaboración de los autores.

\section{Escenarios e infraestructura.}

De los actores encuestados, el $32 \%$ considera que la infraestructura para la cultura no es adecuada y suficiente, mientras que el $6 \%$ considera que son adecuados y suficientes, esta muestra de la población pertenece a los municipios más cercanos Bogotá y que cuentan con espacios adecuados para la cultura. Este asunto, también es identificado como un problema crítico, como se podrá observar en el siguiente apartado.

Ilustración 8. Porcentaje de suficiencia y estado actual de los escenarios e infraestructura cultural

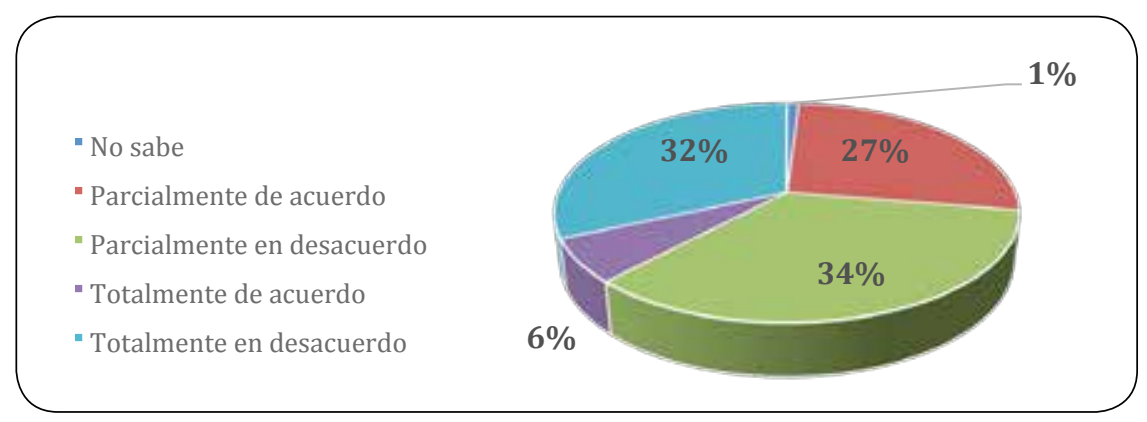

Fuente: elaboración de los autores. 
Apoyo e impulso a Bandas, bibliotecas, música, danza, teatro, patrimonio y eventos tradicionales.

De los actores encuestados, la percepción sobre el apoyo e impulso a las actividades que promociona el IDECUT a partir de sus programas y proyectos en una escala de 1 a 5, es para el sector de bandas, música y bibliotecas es mayor, mientras que para patrimonio, danza y teatro no es el adecuado. Lo que indica que los incentivos de estos sectores no son los suficientes para impulsarlos y garantizar mayor acceso a ellos.

\section{Ilustración 9. Calificación según la oferta cultural}

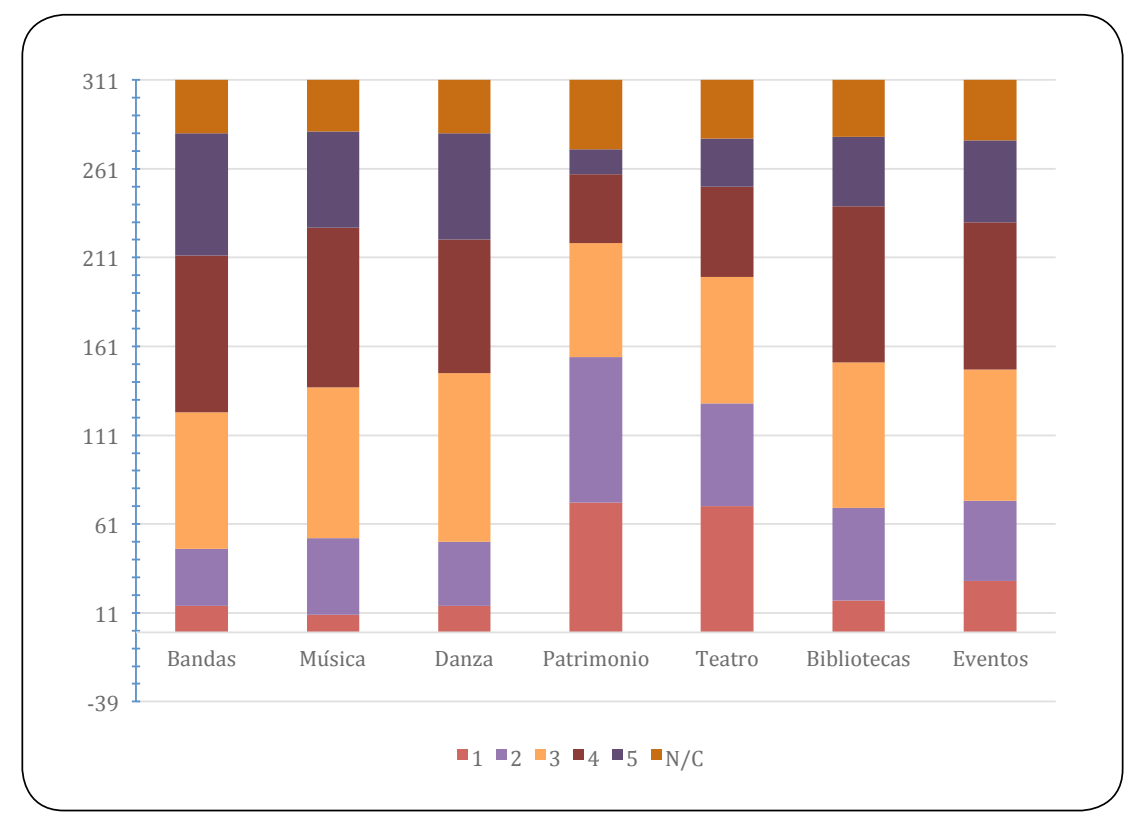

Fuente: elaboración de los autores.

Identificación de situaciones consideradas problemáticas como insumo para el plan decenal de cultura del departamento de Cundinamarca

La identificación de las problemáticas que se pueden considerar necesidades en un contexto dado, son un asunto importante en el proceso de construcción y establecimiento de una política pública. Si se identifican correctamente 
los problemas se podrán elaborar procesos más acertados para darle solución a los mismos. En otras palabras, se espera que el proceso de identificación de problemas genere la activación de las soluciones de los mismos.

El presente apartado tiene por objetivo identificar los principales problemas del sector cultural en el departamento de Cundinamarca, con el fin de lograr eventuales construcciones de lineamientos de política pública cultural con miras a la consolidación del Plan Decenal de Cultura de Cundinamarca. El apartado tiene un ordenamiento sectorial a partir de los problemas identificados y un ordenamiento territorial en quince provincias que permiten una mirada diferenciada y contextualizada de cada uno de ellos.

El presente apartado se desarrolla en cuatro secciones, el primero, se refiere al marco metodológico en el cual se describe de manera detallada todo el proceso de consulta con los actores claves para la identificación de los problemas culturales. En el segundo apartado se identifican y describen todos los problemas identificados a partir del agrupamiento estratégico de los problemas identificados por los actores clave. En el tercer apartado se describe el comportamiento contextual y diferenciado de los problemas en cada una de las provincias. Y finalmente en el cuarto apartado se incluyen las propuestas y soluciones a tener en cuenta para la construcción de los lineamientos de política pública.

\section{Marco metodológico.}

Para el desarrollo del presente estudio se aplicó un modelo participativo para la identificación de los problemas existentes en el sector cultural del departamento de Cundinamarca. Para ello se realizaron consultas a través de entrevistas semiestructuradas, que posteriormente fueron procesadas y problematizadas utilizando la matriz de Vester para identificar relaciones de causalidad entre los problemas; lográndose así todo lo anterior por medio de una identificación por provincias para precisar una mayor diferenciación social y demográfica de los problemas identificados.

\section{Marco conceptual.}

Para el desarrollo de la identificación de problemas se tomaron en cuenta dos marcos teóricos referenciales para el estudio de las políticas públicas: primero, el modelo secuencial, que es de corte racional y permite analizar 
el ciclo de las políticas públicas agrupadas en fases (Roth, 2009): Identificación de problemas, formulación, toma de decisiones, implementación y evaluación; y segundo, el marco de análisis narrativo que es de corte constructivista, posibilitando con ello una mayor relevancia de los argumentos y narrativas de los actores consultados para la identificación de los problemas culturales en el departamento de Cundinamarca. Ambos marcos cumplen con propósitos precisos orientados a sistematizar las narrativas de los actores claves del escenario cultural en la identificación de los problemas del sector.

\section{Espacialidad.}

Para la identificación de los problemas se realizó un proceso participativo de consulta por muestreo no probabilístico, para ello se desarrollaron entrevistas con actores claves en las zonas concertadas con el IDEGUT. El criterio de selección de las salidas de campo fue el de la regionalización, en concordancia con las mesas de trabajo realizadas en un ejercicio participativo el $12 \mathrm{y}$ 13 de agosto de 2015.

Las diferentes zonas consultadas se organizaron por regiones, esto permitió revelar el enfoque regional y cultural que ha marcado el desarrollo histórico del departamento y que al día de hoy sigue siendo un criterio relevante en el sector cultural del departamento para el diseño e implementación de acciones institucionales. Además, hizo posible una ampliación del alcance espacial de las consultas y de igual manera propició una diferenciación sobre las problemáticas que enfrenta la cultura en Cundinamarca, de tal forma que se logró el siguiente ordenamiento espacial.

Tabla 5. Identificación de provincias que corresponden a cada una de las zonas intersectoriales para el estudio de identificación de problemas de cultura

\begin{tabular}{|c|c|c|c|c|}
\hline & \multicolumn{4}{|c|}{ Región } \\
\hline & Fusagasugá & Villeta & Zipaquirá & Cáqueza \\
\hline \multirow{4}{*}{ Provincia } & Sumapáz & Gualivá & Sabana Centro & Oriente \\
\hline & Soacha & Rionegro & Almeidas & Medina \\
\hline & Alto Magdalena & Bajo Magdalena & Ubaté & Guavio \\
\hline & Tequendama & Magdalena Centro & Sabana Occidente & - \\
\hline
\end{tabular}

Fuente: elaboración de los autores. 
Se incluye a continuación el mapa del departamento de Cundinamarca y sus provincias con la división regional y distribución de las salidas de campo.

Ilustración 10. División político administrativa del Departamento de Cundinamarca

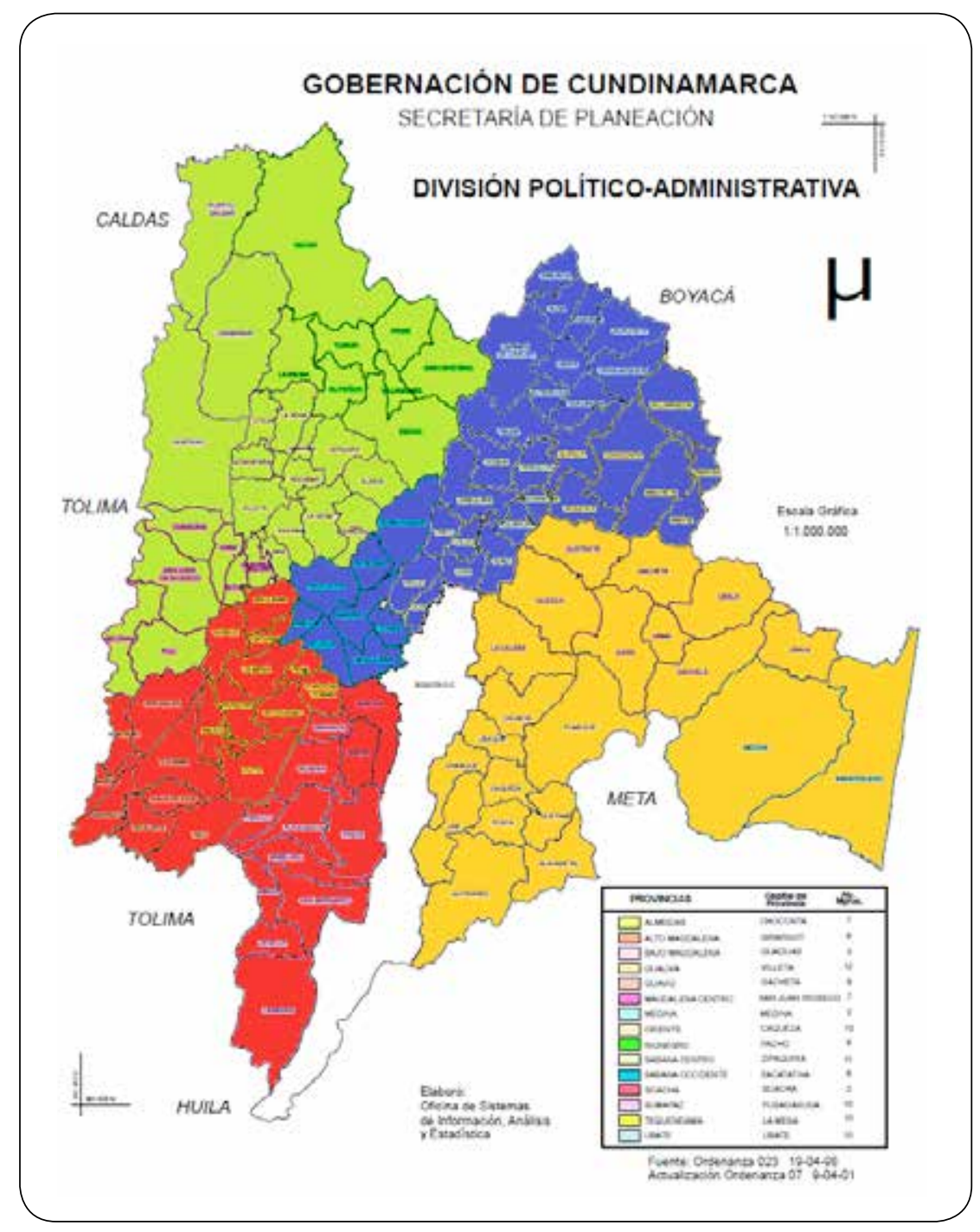

Fuente: Elaboración de los autores. Secretaría de Planeación de la Gobernación de Cundinamarca. 


\section{Actores.}

Para la ejecución de la consulta a los actores claves se realizó un proceso participativo en 10 mesas de trabajo dispuestas para la identificación de las falencias y fortalezas del sector cultural con el objeto de lograr obtener estrategias y soluciones.

Cada mesa de trabajo se acompañó de los funcionarios líderes del IDECUT, destacando experiencias exitosas de algunos municipios como Funza, Pandi, Chía, Tocancipá, entre otros.

Entre los actores que participaron en las mesas de trabajo están:

- Directores.

- Gestores culturales.

- Líderes de cultura.

- Actores asociados al sector cultural en el departamento de Cundinamarca.

\section{La unidad de análisis.}

La unidad de análisis está determinada por las personas que participaron en las entrevistas y las encuestas semiestructuradas, la cuales fueron identificadas y seleccionadas para que su muestra estuviera presente en las regiones seleccionados, se consideró a cada entrevistado como unidad de análisis porque a partir de dichas entrevistas se derivaron varios problemas identificados, de tal forma que una persona no es equivalente a un problema. Se realizaron en total 44 entrevistas y 311 encuestas presenciales y 27 encuestas virtuales, bajo la metodología de encuestas y entrevistas semiestructuradas.

\section{Las variables.}

Sobre las variables identificadas para la presente identificación de problemas es importante diferenciar dos niveles. Primero, existen unas variables generales que están determinadas por un abordaje institucional en el cual los problemas se identificaron a partir de las siguientes tres variables: agenda sistémica, implementación de la política y, agenda gubernamental, es importante señalar que estas variables se construyeron antes que se realizaran las entrevistas y se utilizaron como ejes estructurantes para la discusión de los problemas 
de la cultura. Por otra parte, hay un segundo grupo de variables que son los problemas identificados a partir del proceso de consulta, identificándose un total de 20 variables o problemas del sector cultural, los cuales se reseñan a continuación (los problemas enunciados no están en orden jerárquico):

\section{Problemas base}

Los asuntos culturales no son prioritarios para el gobierno local y departamental.

1. Las acciones (políticas públicas) no corresponden con la realidad.

2. Falta de Normatividad.

3. Poca oferta cultural en algunos municipios.

4. Debilidad institucional y sectorialidad.

5. Diversidad cultural en los municipios.

6. Falta de arraigo y de identidad.

7. Politización y corrupción.

8. Falta fortalecer los procesos culturales.

9. Falta de comunicación.

10. Falta de formación e incentivos.

11. Pocos recursos humanos.

12. Pocos recursos económicos.

13. Falta de gestión.

14. Falta de eficacia.

15. Poca voluntad política.

16. Poca Inclusión.

17. Falta cobertura.

18. Falta de indicadores.

19. No se garantiza el acceso a la oferta cultural.

20. Falta de infraestructura y espacios culturales adecuados.

Es oportuno señalar que se identificaron problemas que son muy similares; sin embargo, los matices diferenciadores están determinados por el enfoque con el cual los actores consultados percibieron los problemas en cada una de las regiones. 


\section{Las observaciones.}

Teniendo presente que el estudio busca la identificación de los problemas del sector cultural, es oportuno señalar que en la mayoría de las entrevistas, los actores consultados identificaron más de un problema, por eso, las observaciones fueron determinadas por la sumatoria de todos los problemas identificados por las unidades de análisis, lo que arrojó un total de 618 observaciones.

Por eso es importante tener en cuenta la diferencia entre el número de entrevistas y el número de problemas identificados, de hecho se realizaron 311 encuestas presenciales, 27 encuestas virtuales y 44 entrevistas (unidad de análisis) que arrojaron un total de 20 problemas identificados (observaciones).

\section{Proceso de consulta y procesamiento de la información.}

Las entrevistas semiestructuradas se desarrollaron a través de un riguroso proceso de identificación de los actores (mapeo), los cuales fueron previamente contactados para organizar una agenda de consultas en terreno. Lo que significó un desplazamiento del grupo de investigadores por 4 regiones del departamento y 7 reuniones del sector cultura realizadas en distintos municipios, donde se realizó el trabajo de campo.

\section{El uso de la matriz de Vester para el procesamiento de la información.}

Para el procesamiento de la información se hizo uso de la matriz de Vester, esta herramienta es útil para el desarrollo y discusión de problemas. Una característica relevante es que esta herramienta permite un abordaje sistémico, ya que se busca la incorporación de las diferentes perspectivas de los actores, en donde cada uno tiene una mirada distinta sobre la narrativa de los problemas percibidos, lo cual es concurrente con el marco teórico narrativo de enfoque constructivista que se reseñó al inicio de este documento.

El método de la matriz de Vester permite identificar relaciones de causalidad entre los problemas identificados y a partir de ello darles un ordenamiento lógico a partir de los mismos, dicho ordenamiento permite estructurar los problemas en las siguientes cuatro categorías:

- Problemas activos, se consideran como problemas activos aquellos que influyen en los demás problemas y que no son influenciados por ellos. 
- Problemas críticos, se consideran como problemas críticos aquellos que son influyentes y al mismo tiempo son influenciados.

- Problemas pasivos, se consideran como problemas pasivos aquellos que no son influyentes pero si son muy influenciados.

- Problemas inertes, se consideran como problemas inertes aquellos que no son influyentes y tampoco son influenciados.

A partir de esta clasificación, se priorizó el estudio de los problemas activos y críticos, porque su identificación y solución incide en la solución de los demás problemas.

Este enfoque parte de comprender los problemas como un todo sistémico y no como un abordaje lineal donde se debe buscar un problema que sea el gran articulador de los demás. Lo anterior se considera porque los problemas de la cultura, entendidos como de carácter social tienen diferentes miradas en tanto hay diferentes actores que le dan diferentes peso y valor. Por eso, la búsqueda y consecución de una priorización de problemas permitirá un abordaje más integral en la identificación de los mismos en el tema de la cultura que garantice una lógica inclusiva de los mismos.

\section{Utilización del marco lógico.}

Sobre la base de los productos resultantes del procesamiento de información de la matriz de Vester, se utilizaron los problemas identificados para aplicarlos al modelo de marco lógico, esta herramienta metodológica permite estructurar la información en términos secuenciales de finalidad, objetivos, componentes y actividades, lo que permite con mucha precisión trasladar los problemas a elementos indicativos de lineamientos generales de política pública (CEPAL, 2004).

El marco lógico permite establecer claramente con un hilo conductor y coherente cuales son los problemas identificados y como se resuelve cada uno a partir de soluciones concretas que responden a cada uno de los problemas. Así las cosas, a partir de problemáticas que resultaron de las mesas de trabajo se realizarán propuestas acordes a ellas. En cada caso se establecerá un problema sombrilla que encierra los demás al igual se propondrá una solución general que engloba las microestrategias propuestas. 
Utilización de software para el procesamiento de la información.

Finalmente, es oportuno señalar que para la digitación y procesamiento estadístico de la información cualitativa se hizo uso del programa computacional Atlas-ti, este programa permite organizar y hacer aproximaciones cuantitativas a información de corte cualitativo, que es el caso de la presente investigación que se basó en narrativas (cualitativas) de los actores consultados. Para los aspectos cuantitativos se utilizaron los programas SPSS y Eviews.

\section{Caracterización de los asuntos considerados problemáticos como insumo para la política cultural del departamento de Cundinamarca}

\section{Identificación de los problemas.}

A partir del proceso de consulta a los actores claves se identificaron 20 grandes problemas que se reiteraron a partir de un ejercicio participativo en mesas de trabajo, encuestas y entrevistas que se reflejan particularmente en desarticulación institucional y falta de agendamiento de los asuntos culturales en el departamento y en los diferentes municipios.

\section{Descripción de los problemas identificados.}

Se plantea un problema principal que rodea los 20 identificados para posteriormente proponer según la metodología del marco lógico una gran solución que responda con los diferentes objetivos y soluciones. A la fecha, no se evidencia que la administración pública departamental haya priorizado los asuntos culturales, especialmente porque no ingresan en la agenda pública o se agendan de manera secundaria. En esta misma descripción se evidencia que los asuntos culturales no están determinados a largo plazo desde el departamento y hacia los municipios. En la medida que cada municipio está concentrado en fomentar sus costumbres, tradiciones y patrimonio de manera independiente sin estrategias de articulación institucional.

\section{Desarticulación institucional.}

Es un problema que se describe por la mayoría de los entrevistados y encuestados, si bien existen fortalezas evidentes en las diferentes provincias se planteó que existe una falta de articulación y sinergia entre provincias y 
entre los niveles departamental y municipal, lo cual ha generado dificultades que se reflejan en la pérdida de oportunidades de crecimiento regional y municipal. Se evidenciaron fortalezas en materia de artes, cultura y patrimonio entre municipios pero no actúan como provincia, lo que afecta no solo las sinergias institucionales sino la posibilidad de presentar proyectos conjuntos para la consecución de recursos.

\section{Falta continuidad en los procesos.}

Los asuntos culturales dependen del funcionario de turno, por tanto, si no hay una política de Estado cultural que se transmita del nivel nacional al departamental y municipal será muy difícil crear una conciencia a largo plazo respecto al sector cultural. El problema está en que no se refleja la continuidad de los procesos culturales porque se relaciona con el interés que le imprima la autoridad local al tema, lo que indica que, si la administración no prioriza el tema cultural es necesario esperar a un siguiente período donde sea prioritario.

\section{Falta comunicación con los entes culturales.}

Se evidencia que no existe una relación permanente y fluida con las organizaciones públicas culturales y los municipios, si bien se encuentran ejercicios aislados se concluye que no es permanente ni planeada la interlocución con las entidades públicas y/o organizaciones culturales privadas que puedan llegar a aportar convenios, proyectos o programas conjuntos para los municipios o el departamento.

\section{Faltan políticas claras frente al sector cultura.}

Si bien existen esfuerzos independientes en algunos municipios, no se encuentra una política departamental clara y a largo plazo que priorice el sector cultural con un concepto unificado. La desarticulación institucional se ha comprendido por parte de los diferentes actores como falta de claridad en los lineamientos del sector cultural, lo que se ha reflejado en los reclamos de la comunidad en no visualizar resultados culturales prioritarios.

\section{Faltan recursos para visualizar y realizar procesos artísticos y culturales.}

La desarticulación entre los niveles nacional, departamental y municipal demostró a partir del ejercicio participativo realizado, que la falta de recursos 
económicos para realizar proyectos artísticos y culturales es una necesidad en la mayoría de los municipios del departamento. Se refleja una ausencia en la planeación económica para disponer de recursos en proyectos y eventos que pueden aportar en la ejecución de una política pública cultural.

\section{Falta conocimiento de la cultura y la historia.}

De las mesas de trabajo se evidencia una falta de apropiación del patrimonio histórico y cultural de los cundinamarqueses, lo que evidencia que los hacedores de política no se han concentrado en construir un conocimiento colectivo de la cultura del departamento como un todo, y lo que se refleja es una multiplicidad de concepciones que alejan una política integral.

\section{Ausencia de valoración por lo nuestro, falta de identidad y arraigo.}

Es generalizada la percepción de la falta de conciencia por el cundinamarqués en valorar sus tradiciones y costumbres culturales, se expresó en las mesas de trabajo que el concepto de cultura no se ha interiorizado lo suficiente como para generar una política pública adecuada, esto se evidencia desde los gestores hasta el campesino común. Lo anterior se traduce en la falta de identidad como región.

\section{Ausencia de indicadores.}

A partir de la revisión de la información se manifiesta la dificultad de que no existan indicadores culturales de medición para el departamento y algunos municipios, esto afecta el diseño de una política acorde a los fenómenos de medición. Dado que se improvisa constantemente con actividades aisladas y no se generan acciones de mejoramiento dado que no hay una valoración cuantitativa del sector cultural.

\section{Validación y consolidación.}

El proceso de validación y de consolidación de los problemas identificados junto con sus soluciones, como se indica en el apartado de metodología, es de carácter participativo y vinculante; esto quiere decir que a los actores que participaron en la identificación de problemas y que se les aplicó el instrumento de medición -encuesta- se les consultó por medio de un formulario si consideraban o no que las soluciones respondían a los problemas identificados; 
que valoraran en una escala de 1 a 4 , siendo 1 menos importante y 4 muy importante los problemas propuestos. Para ello se contó con la participación de menos del $15 \%$ de los actores, teniendo como resultado lo siguiente:

\section{Ilustración 11. Valoración de los problemas identificados}

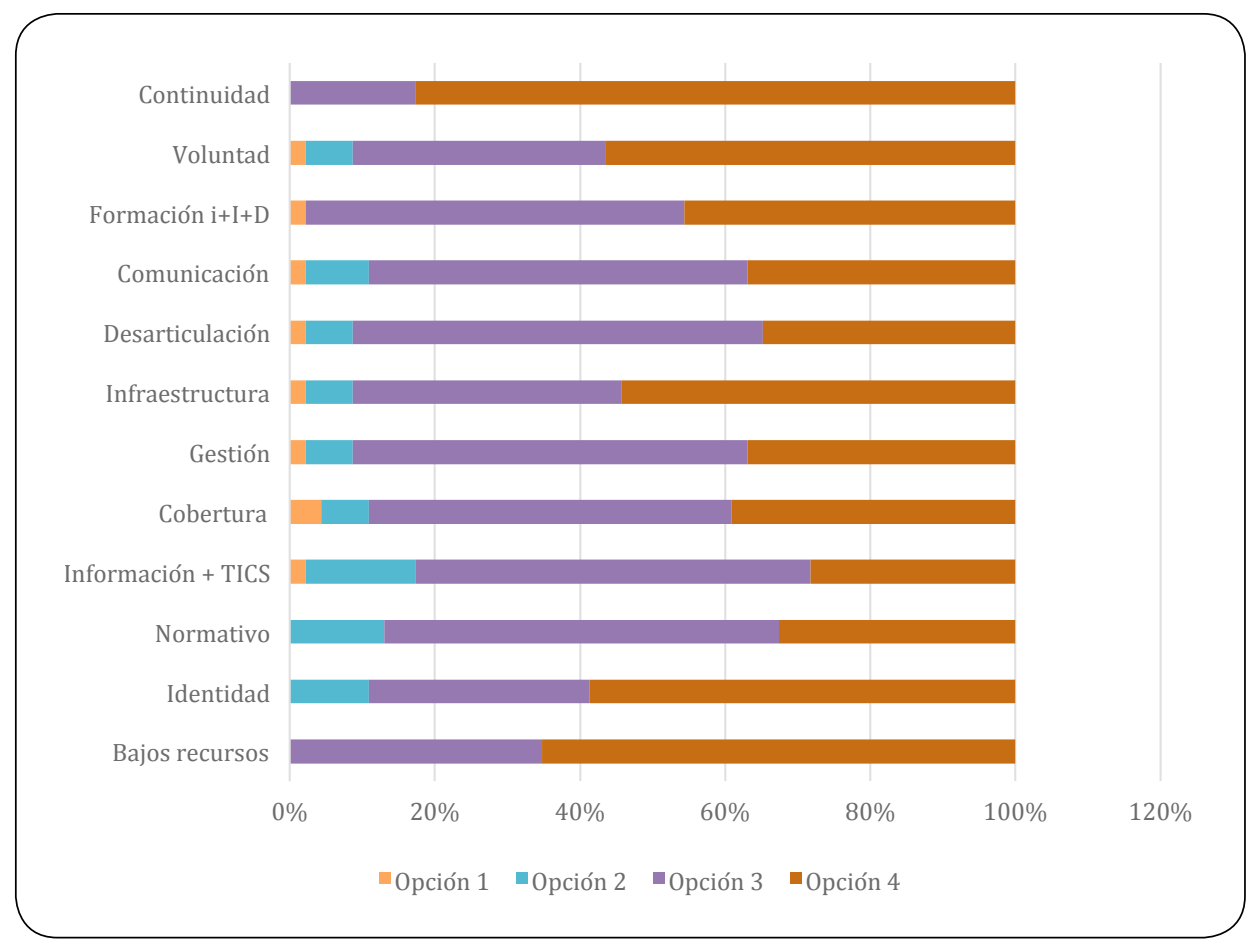

Fuente: Elaboración de los autores.

Para los problemas: continuidad, voluntad política, infraestructura, identidad y bajos recursos, los consultados los encuentran como muy importantes. Los problemas de continuidad en los procesos y bajos recursos es uno de los más importantes para los consultados, puesto que ninguno de ellos lo calificó entre 1 y 2. El porcentaje de validación corresponde al resultado obtenido del ejercicio de validación con los actores consultados. Con base en la información de validación, a continuación se presenta la categorización para atender de acuerdo a la prioridad de los problemas se encuentra distribuida de la siguiente manera: 
Tabla 6. Porcentaje de validación por problema y clasificación del mismo

\begin{tabular}{|c|c|c|c|}
\hline$\#$ & Problema & $\stackrel{\%}{\text { Validación }}$ & $\begin{array}{l}\text { Tipo de } \\
\text { Problema }\end{array}$ \\
\hline 1 & $\begin{array}{l}\text { Baja continuidad en los procesos de gestión y } \\
\text { ejecución de programas y proyectos }\end{array}$ & $83 \%$ & Crítico \\
\hline 2 & $\begin{array}{l}\text { Bajos recursos, fuentes y canalización de } \\
\text { financiación }\end{array}$ & $65 \%$ & Crítico \\
\hline 3 & Falta de apropiación de la identidad cultural & $59 \%$ & Crítico \\
\hline 4 & Falta de voluntad e interés por la cultura & $57 \%$ & Crítico \\
\hline 5 & Falta de infraestructura adecuada y suficiente & $54 \%$ & Crítico \\
\hline 6 & $\begin{array}{l}\text { Baja articulación tanto entre actores e } \\
\text { instituciones del sistema como con otros sectores }\end{array}$ & $57 \%$ & Activo \\
\hline 7 & Falta de gestión y de alcance institucional & $54 \%$ & Activo \\
\hline 8 & Falta de normas, control y regulación del sistema & $54 \%$ & Activo \\
\hline 9 & $\begin{array}{l}\text { Baja comunicación y divulgación tanto de la } \\
\text { oferta cultural como entre los actores e instituciones } \\
\text { del sistema como para la participación ciudadana }\end{array}$ & $52 \%$ & Activo \\
\hline 10 & $\begin{array}{l}\text { Bajo nivel de formación y de generación de } \\
\text { conocimiento (educación e investigación) }\end{array}$ & $52 \%$ & Activo \\
\hline 11 & $\begin{array}{l}\text { Bajo nivel de información y conocimiento así } \\
\text { como de apropiación y uso de TIC }\end{array}$ & $52 \%$ & Activo \\
\hline 12 & $\begin{array}{l}\text { Baja cobertura y acceso de la población a los } \\
\text { programas y proyectos }\end{array}$ & $50 \%$ & Activo \\
\hline
\end{tabular}

Fuente: Elaboración de los autores.

\section{Alternativas de solución}

Tal y como se anunció anteriormente se busca que a los problemas y causas expresadas en el numeral anterior, se formulen soluciones y estrategias posibles. A continuación se presenta el conjunto de alternativas planteadas, y que además pasaron, como se verá en el siguiente apartado, por un proceso de evaluación.

Se debe buscar una priorización real de los asuntos culturales en la agenda pública del departamento y que ello se refleje en las agendas municipales, de tal manera que, brindándole una visión prospectiva a los asuntos culturales 
se espera lograr estrategias de articulación institucional, planeación asertiva, diseño de indicadores, fluidez en la comunicación institucional, entre otros.

\section{Articulación institucional.}

Se propone una comunicación fluida entre municipios, provincias y departamento, lo que permitirá que se diseñe una política pública cultural que se refleje en todos los niveles de gobierno, así mismo, se requiere de gestión y sinergia entre las entidades públicas a través de acciones en las políticas culturales territoriales que tengan en cuenta las particularidades de las diferentes expresiones y prácticas culturales comunitarias y el reconocimiento de sus identidades. (Cali, 2013) Buscar un mejor acompañamiento del Ministerio de Cultura junto con las secretarías de cultura, departamentales y municipales del departamento de Cundinamarca que apoyen las redes de cultura comunitaria ya existentes y las que se pretenden formar, para avanzar en el desarrollo y entendimiento de la política pública de Cultura propuesta (Cali, 2013). El propósito de lograr la articulación institucional implica agentes relevantes - privados o públicos-involucradas, ejerzan un liderazgo impulsado por el consenso de tal suerte que se garantice la conservación y protección de sus procesos culturales.

\section{Diseñar procesos culturales continuos.}

Se espera que cuando los asuntos culturales hacen parte de las prioridades de la agenda pública culturales, los procesos que se diseñen reflejen la planeación a largo plazo, la formulación de indicadores, metas y objetivos con prospectiva futura. Por tanto, se expresa la importancia de articular y ejecutar convenios permanentes en temas culturales independientemente del periodo de gobierno; prever y proyectar las fuentes de financiación de proyectos culturales de tal manera que sean planeadas con independencia de los funcionarios que coordinen los asuntos culturales; impulsar la normatividad necesaria para generar sostenimiento a los proyectos culturales sin estar dependiendo de la variabilidad de la estampilla verde.

\section{Diseñar estrategia de comunicación con entes culturales.}

Es fundamental que el departamento se enfoque en determinar cuáles serían los actores estratégicos en el sector público y privado para los asuntos 
culturales, de tal manera que se puedan lograr aliados estratégicos a largo plazo en este sector. Así las cosas, se proponen talleres de sensibilización sobre literatura cultural de la región, fortalecer investigación en temas ancestrales y populares de la música y el arte rupestre en Cundinamarca, llegando a formar Directores Culturales. Por otro lado se hace necesario el fomento de medios audiovisuales y artes plásticas con diferentes entidades estatales como el Ministerio de Tecnologías de la Información y Comunicación información y comunicaciones para que por medio de sus programas pueda profesionalizar el trabajo de los gestores culturales y fortalecer su proceso educativo en la población que accede a la cultura en cada uno de los municipios.

\section{Diseñar políticas culturales claras en el departamento.}

Se propone que la política pública cultural debe ser prospectiva e incluir áreas necesarias en su diseño como: bellas artes, artes plásticas y audiovisuales. Así mismo, se considere un impulso al Consejo de Cultura de tal manera que juegue un rol multiplicador en los municipios, al orientar asuntos culturales de manera estratégica para todos los municipios en articulación con el departamento y sobretodo, con la suficiente divulgación para que la comunidad las conozca y las apropie.

\section{Destinar recursos a procesos culturales.}

Los recursos para un sector no solamente están relacionados con el factor económico o financiero, también hacen referencia al factor humano, así las cosas es menester ampliar el recurso humano y brindar una capacitación adecuada en asuntos culturales. Lo anterior requiere necesariamente una capacitación a los mandatarios locales en asuntos culturales de tal suerte que comprendan la importancia del sector y la orientación estratégica y prospectiva de la política pública cultural.

Por otro lado, es importante que el aporte económico de las empresas privadas no esté sujeto solamente a los recursos para eventos públicos como ferias y conciertos, dado que solo hay un costo-beneficio para la empresa en publicidad y patrocinio y no para la instancia cultural. Una propuesta sería una alianza público-privada en el impulso del sector generando autofinanciamiento del sector cultural y beneficios de parte y parte. En este apartado se propone también un mejor aprovechamiento de los recursos que genera el 
turismo en el departamento, de tal manera que aporten a procesos culturales de relevancia y no improvisados.

\section{Impulsar una cátedra ciudadana para impulsar conocimientos culturales.}

El departamento y los municipios han evidenciado en la comunidad una ausencia de conocimientos culturales que afectan el empoderamiento de todo ciudadano frente a sus tradiciones, raíces y costumbres. La formación y la apropiación cultural comienza en casa y en las aulas, por tanto, una propuesta es que se diseñe una catedra en los Colegios Públicos de Cundinamarca en los que se trabajen aspectos educativos dirigidos a fomentar el conocimiento cultural de la región. Así mismo, se propugna por priorizar el patrimonio material e inmaterial de cada provincia, e impulsar la dotación de insumos como instrumentos musicales, atuendos y materiales artísticos para la realización de procesos adecuados de formación.

\section{Impulsar una estrategia de empoderamiento ciudadano por el patrimonio cultural.}

En este apartado es clave que se impulse una estrategia que permita empoderar al ciudadano en asuntos culturales, impulsar de manera unificada y bajo estrategias de planeación articuladas actividades artísticas y culturales que faciliten el intercambio de expresiones artísticas, proyectos y programas. En conclusión se busca una nueva forma de ver la cultura en Cundinamarca, mediante procesos culturales y artísticos que se trabajen en las bases sociales, reconociendo la cultura como generador de desarrollo y un cambio de actitud o percepción en las comunidades frente a los procesos culturales del departamento.

\section{Formulación de indicadores culturales.}

Es necesario formular indicadores que permitan medir los fenómenos culturales en el departamento y los municipios de Cundinamarca, así las cosas se requiere de un modelo estadístico que unifique las actividades e intereses de la región de tal suerte que compile la información cuantitativa que aporte los insumos para una política pública cultural a largo plazo. 


\section{"No hacer nada".}

Como lo plantea el profesor Ordóñez Matamoros (2013), dentro de las posibles alternativas de solución se encuentra el "no hacer nada". Para el caso específico esto implica que la administración departamental no formule política y sigan los procesos tal como se han desarrollado en los últimos años.

En el siguiente capítulo, y luego de haber realizado el proceso de la validación, evaluación y concertación tanto con los tomadores de decisión como con los actores que hacen parte del sector cultural en el departamento de Cundinamarca, se presenta la estructura y contenido del Plan Decenal y las herramientas para su institucionalización. 



\section{Capítulo 5}

\section{PLAN DEGENAL DE GULTURA 2016-2026 DEL DEPARTAMENTO DE GUNDINAMARGA}

Como resultado del proceso realizado en el departaAmento de Cundinamarca, de las mesas de trabajo, de la validación de los instrumentos de medición y del análisis del árbol de problemas y de evaluación de las alternativas de solución se diseñó el plan decenal de cultura para el departamento. El documento se construyó en clave multidimensional, es decir con alcance a todas las manifestaciones y diversidades culturales del Departamento. Así mismo el plan se estructuró con un enfoque diferencial e inclusivo para las comunidades étnicas y diversamente hábiles. El plan decenal tiene una validación con una desviación estándar de 0,65 y un margen de error del $5 \%, 9$ objetivos estratégicos, 31 indicadores, 174 metas entre corto, mediano y largo plazo. Como resultado de la evaluación, se observa que posee un estimado del $72 \%$ de viabilidad técnica, administrativa, política, económica, de simplicidad y de impacto ambiental. Lo anterior significa, que existen algunas variables y condiciones externas que pueden desestabilizar los planes de implementación y monitoreo y por tanto generar una brecha entre lo planeado y lo ejecutado: este es el reto de las administraciones que ejecutaran e implementarán el Plan.

\section{Descripción del Plan Decenal}

A continuación se presenta el resultado del proceso de investigación destacando los metaproblemas identificados 
y las alternativas de solución establecidas. Además, se incluyen tanto las metas a corto, mediano y largo plazo como los indicadores y la evaluación de viabilidad. El orden de los metaproblemas y sus consecuentes objetivos estratégicos corresponde a la valoración obtenida del proceso de evaluación por parte de los actores.

\section{Metaproblema 1: Baja continuidad en los procesos de gestión y ejecución de programas y proyectos.}

Objetivo estratégico 1: Facilitar la continuidad de los procesos culturales.

\begin{tabular}{|c|c|c|c|}
\hline Indicadores & $\begin{array}{l}\text { Corto plazo } \\
\text { (1 a } 4 \text { años) }\end{array}$ & $\begin{array}{l}\text { Mediano plazo } \\
\text { (5 a } 8 \text { años) }\end{array}$ & $\begin{array}{l}\text { Largo plazo } \\
\text { (9 a } 10 \text { años) }\end{array}$ \\
\hline \multirow[t]{3}{*}{$\begin{array}{l}\% \text { de proyectos } \\
\text { y programas con } \\
\text { continuidad a nivel } \\
\text { departamental y } \\
\text { municipal }\end{array}$} & $\begin{array}{l}\text { Evaluar los } \\
\text { proyectos y } \\
\text { programas que se } \\
\text { ejecutaron en la } \\
\text { vigencia anterior. }\end{array}$ & $\begin{array}{l}\text { Evaluar los } \\
\text { proyectos y } \\
\text { programas que se } \\
\text { ejecutaron en la } \\
\text { vigencia anterior. }\end{array}$ & $\begin{array}{l}\text { Evaluar los proyectos } \\
\text { y programas que } \\
\text { se ejecutaron en la } \\
\text { vigencia anterior. }\end{array}$ \\
\hline & $\begin{array}{l}\text { Determinar la } \\
\text { viabilidad de la } \\
\text { continuidad de } \\
\text { los proyectos y } \\
\text { programas de la } \\
\text { vigencia anterior. }\end{array}$ & $\begin{array}{l}\text { Determinar la } \\
\text { viabilidad de la } \\
\text { continuidad de } \\
\text { los proyectos y } \\
\text { programas. }\end{array}$ & $\begin{array}{l}\text { Determinar la } \\
\text { viabilidad de la } \\
\text { continuidad de } \\
\text { los proyectos y } \\
\text { programas. }\end{array}$ \\
\hline & $\begin{array}{l}\text { Propiciar } \\
\text { mecanismos } \\
\text { tanto para la } \\
\text { rápida gestión } \\
\text { de los procesos } \\
\text { contractuales } \\
\text { para el personal } \\
\text { requerido en } \\
\text { la ejecución de } \\
\text { los programas y } \\
\text { proyectos, para } \\
\text { garantizar mínimo } \\
\text { diez (10) meses de } \\
\text { ejecución al año }\end{array}$ & $\begin{array}{l}\text { Propiciar } \\
\text { mecanismos } \\
\text { tanto para la } \\
\text { rápida gestión } \\
\text { de los procesos } \\
\text { contractuales } \\
\text { para el personal } \\
\text { requerido en } \\
\text { la ejecución de } \\
\text { los programas y } \\
\text { proyectos, para } \\
\text { garantizar mínimo } \\
\text { diez (10) meses de } \\
\text { ejecución al año. }\end{array}$ & $\begin{array}{l}\text { Propiciar mecanismos } \\
\text { tanto para la } \\
\text { rápida gestión } \\
\text { de los procesos } \\
\text { contractuales para el } \\
\text { personal requerido } \\
\text { en la ejecución } \\
\text { de los programas } \\
\text { y proyectos, para } \\
\text { garantizar mínimo } \\
\text { diez (10) meses de } \\
\text { ejecución al año. }\end{array}$ \\
\hline
\end{tabular}




\begin{tabular}{|c|c|c|c|}
\hline Indicadores & $\begin{array}{l}\text { Corto plazo } \\
\text { (1 a } 4 \text { años) }\end{array}$ & $\begin{array}{l}\text { Mediano plazo } \\
\text { (5 a } 8 \text { años) }\end{array}$ & $\begin{array}{l}\text { Largo plazo } \\
(9 \text { a } 10 \text { años })\end{array}$ \\
\hline & & $\begin{array}{l}\text { Retroalimentar } \\
\text { el proceso y } \\
\text { determinar } \\
\text { mecanismos que } \\
\text { contribuyan a } \\
\text { dar continuidad } \\
\text { a los programas y } \\
\text { proyectos }\end{array}$ & $\begin{array}{l}\text { Realizar una } \\
\text { evaluación de ciclo } \\
\text { tanto técnica como de } \\
\text { carácter } \\
\text { participativo para } \\
\text { establecer el impacto } \\
\text { y efecto que generó } \\
\text { la implementación } \\
\text { de las acciones en la } \\
\text { continuidad de los } \\
\text { procesos }\end{array}$ \\
\hline
\end{tabular}

\begin{tabular}{|c|c|c|c|c|c|}
\hline $\begin{array}{c}\text { SIMPLICIDAD } \\
\text { (sencillez para } \\
\text { su adopción) }\end{array}$ & $\begin{array}{c}\text { VIABILIDAD } \\
\text { ADMINISTRATIVA } \\
\text { (capacidad } \\
\text { administrativa, de } \\
\text { recursos humanos y } \\
\text { técnicos) }\end{array}$ & $\begin{array}{l}\text { VIABILIDAD } \\
\text { POLÍTICA } \\
\text { (popularidad de } \\
\text { la alternativa) }\end{array}$ & $\begin{array}{c}\text { VIABILIDAD } \\
\text { ECONÓMICA } \\
\text { (ise cuenta con } \\
\text { los recursos?) }\end{array}$ & $\begin{array}{c}\% \text { DE } \\
\text { VIABILIDAD }\end{array}$ & $\begin{array}{c}\text { IMPACTO } \\
\text { AMBIENTAL }\end{array}$ \\
\hline 5 & 5 & 3 & 5 & $90 \%$ & BAJO \\
\hline
\end{tabular}

Metaproblema 2: Bajos recursos, fuentes y canalización de financiación.

\section{Objetivo estratégico 2: Promover el aumento de los recursos $y$ fuentes disponibles.}

\begin{tabular}{llll}
\multicolumn{1}{c}{ Indicadores } & \multicolumn{1}{c}{$\begin{array}{c}\text { Corto plazo } \\
(\mathbf{1} \text { a } 4 \text { años })\end{array}$} & $\begin{array}{c}\text { Mediano plazo } \\
\text { (5 a } \mathbf{8} \text { años })\end{array}$ & $\begin{array}{c}\text { Largo plazo } \\
\text { (9 a 10 años })\end{array}$ \\
$\begin{array}{l}\text { \% de recursos } \\
\text { disponibles y } \\
\text { ejecutados para } \\
\text { la cultura por } \\
\text { municipio y } \\
\text { departamento }\end{array}$ & $\begin{array}{l}\text { Determinar los } \\
\text { recursos destinados } \\
\text { para la cultura } \\
\text { por municipio y } \\
\text { departamento }\end{array}$ & $\begin{array}{l}\text { Propiciar APP } \\
\text { para la gestión de } \\
\text { recursos }\end{array}$ & $\begin{array}{l}\text { Propiciar APP para la } \\
\text { gestión de recursos }\end{array}$ \\
& $\begin{array}{l}\text { Aumentar } \\
\text { Establecer las } \\
\text { fuentes financieras } \\
\text { actuales y las } \\
\text { posibles alternativas }\end{array}$ & $\begin{array}{l}\text { los recursos que } \\
\text { por municipio } \\
\text { se destinan a la } \\
\text { cultura }\end{array}$ & $\begin{array}{l}\text { Aumentar } \\
\text { progresivamente los } \\
\text { recursos que por } \\
\text { municipio se destinan } \\
\text { a la cultura }\end{array}$ \\
& &
\end{tabular}




\begin{tabular}{|c|c|c|c|}
\hline Indicadores & $\begin{array}{l}\text { Corto plazo } \\
\text { (1 a } 4 \text { años) }\end{array}$ & $\begin{array}{l}\text { Mediano plazo } \\
\text { (5 a } 8 \text { años) }\end{array}$ & $\begin{array}{l}\text { Largo plazo } \\
(9 \text { a } 10 \text { años })\end{array}$ \\
\hline $\begin{array}{l}\% \text { de fuentes } \\
\text { financieras que } \\
\text { apoyan la }\end{array}$ & $\begin{array}{l}\text { Propiciar APP } \\
\text { para la gestión de } \\
\text { recursos }\end{array}$ & $\begin{array}{l}\text { Formular y } \\
\text { gestionar proyectos } \\
\text { de regalías }\end{array}$ & $\begin{array}{l}\text { Formular y gestionar } \\
\text { proyectos de regalías }\end{array}$ \\
\hline $\begin{array}{l}\text { de proyectos } \\
\text { y programas } \\
\text { culturales }\end{array}$ & $\begin{array}{l}\text { Aumentar } \\
\text { progresivamente } \\
\text { los recursos que } \\
\text { por municipio } \\
\text { se destinan a la } \\
\text { cultura }\end{array}$ & $\begin{array}{l}\text { Aumentar } \\
\text { progresivamente } \\
\text { los recursos que } \\
\text { por municipio } \\
\text { se destinan a la } \\
\text { cultura }\end{array}$ & $\begin{array}{l}\text { Aumentar } \\
\text { progresivamente los } \\
\text { recursos que por } \\
\text { municipio se destinan } \\
\text { a la cultura }\end{array}$ \\
\hline \multirow[t]{2}{*}{$\begin{array}{l}\text { \% de municipios } \\
\text { que realizan una } \\
\text { inversión en la } \\
\text { cultura mínimo } \\
\text { del } 3 \% \text { (en análisis } \\
\text { de Hacienda } \\
\text { Gobernación) }\end{array}$} & $\begin{array}{l}\text { Aumentar } \\
\text { progresivamente } \\
\text { los recursos que } \\
\text { el departamento } \\
\text { asigna al IDECUT } \\
\text { para el desarrollo } \\
\text { de la cultura }\end{array}$ & $\begin{array}{l}\text { Aumentar } \\
\text { progresivamente } \\
\text { los recursos que } \\
\text { el departamento } \\
\text { asigna al IDECUT } \\
\text { para el desarrollo } \\
\text { de la cultura }\end{array}$ & $\begin{array}{l}\text { Aumentar } \\
\text { progresivamente } \\
\text { los recursos que el } \\
\text { departamento asigna } \\
\text { al IDECUT para } \\
\text { el desarrollo de la } \\
\text { cultura }\end{array}$ \\
\hline & $\begin{array}{l}\text { Formular y } \\
\text { gestionar proyectos } \\
\text { con el Ministerio } \\
\text { de Cultura }\end{array}$ & $\begin{array}{l}\text { Institucionalizar } \\
\text { mecanismos y } \\
\text { fuentes para la } \\
\text { financiación del } \\
\text { sector tanto a nivel } \\
\text { municipal como } \\
\text { departamental }\end{array}$ & $\begin{array}{l}\text { Institucionalizar } \\
\text { mecanismos y fuentes } \\
\text { para la financiación } \\
\text { del sector tanto a } \\
\text { nivel municipal como } \\
\text { departamental }\end{array}$ \\
\hline \multirow{2}{*}{$\begin{array}{l}\text { \% de éxito } \\
\text { de proyectos } \\
\text { presentados ante } \\
\text { el Ministerio de } \\
\text { Cultura }\end{array}$} & $\begin{array}{l}\text { Formular y } \\
\text { gestionar proyectos } \\
\text { con organismos } \\
\text { internacionales }\end{array}$ & $\begin{array}{l}\text { Formular y } \\
\text { gestionar proyectos } \\
\text { con el Ministerio } \\
\text { de Cultura }\end{array}$ & $\begin{array}{l}\text { Formular y gestionar } \\
\text { proyectos con el } \\
\text { Ministerio de Cultura }\end{array}$ \\
\hline & $\begin{array}{l}\text { Formular y } \\
\text { gestionar proyectos } \\
\text { de regalías }\end{array}$ & $\begin{array}{l}\text { Formular y } \\
\text { gestionar proyectos } \\
\text { con organismos } \\
\text { internacionales }\end{array}$ & $\begin{array}{l}\text { Formular y } \\
\text { gestionar proyectos } \\
\text { con organismos } \\
\text { internacionales }\end{array}$ \\
\hline
\end{tabular}




\begin{tabular}{|c|c|c|c|}
\hline Indicadores & $\begin{array}{l}\text { Corto plazo } \\
\text { (1 a } 4 \text { años })\end{array}$ & $\begin{array}{l}\text { Mediano plazo } \\
\text { (5 a } 8 \text { años) }\end{array}$ & $\begin{array}{l}\text { Largo plazo } \\
(9 \text { a } 10 \text { años) }\end{array}$ \\
\hline $\begin{array}{l}\text { \% de éxito } \\
\text { de proyecto } \\
\text { de regalías } \\
\text { presentados }\end{array}$ & $\begin{array}{l}\text { Propiciar la } \\
\text { creación de un } \\
\text { Fondo mixto para } \\
\text { la recaudación y } \\
\text { manejo de recursos }\end{array}$ & $\begin{array}{l}\text { Promover la } \\
\text { capacitación a la } \\
\text { población para } \\
\text { la gestión de } \\
\text { proyectos }\end{array}$ & $\begin{array}{l}\text { Crear mecanismos } \\
\text { para disminuir } \\
\text { la inequidad en } \\
\text { la distribución } \\
\text { de recursos por } \\
\text { municipio }\end{array}$ \\
\hline $\begin{array}{l}\text { \% de recursos } \\
\text { de otras fuentes } \\
\text { de financiación } \\
\text { diferentes a las del } \\
\text { sector público }\end{array}$ & $\begin{array}{l}\text { Promover la } \\
\text { capacitación a la } \\
\text { población para } \\
\text { la gestión de } \\
\text { proyectos }\end{array}$ & & \\
\hline $\begin{array}{l}\text { \% de recursos por } \\
\text { línea artística o } \\
\text { demás subsectores } \\
\text { culturales por } \\
\text { municipio y } \\
\text { departamento }\end{array}$ & & & \\
\hline
\end{tabular}

\begin{tabular}{|c|c|c|c|c|c|}
\hline $\begin{array}{c}\text { SIMPLICIDAD } \\
\text { (sencillez para } \\
\text { su adopción) }\end{array}$ & $\begin{array}{c}\text { VIABILIDAD } \\
\text { ADMINISTRATIVA } \\
\text { (capacidad } \\
\text { administrativa, de } \\
\text { recursos humanos y } \\
\text { técnicos) }\end{array}$ & $\begin{array}{l}\text { VIABILIDAD } \\
\text { POLÍTICA } \\
\text { (popularidad de } \\
\text { la alternativa) }\end{array}$ & $\begin{array}{l}\text { VIABILIDAD } \\
\text { ECONÓMICA } \\
\text { (¿se cuenta con } \\
\text { los recursos?) }\end{array}$ & $\begin{array}{c}\text { \% DE } \\
\text { VIABILIDAD }\end{array}$ & $\begin{array}{c}\text { IMPACTO } \\
\text { AMBIENTAL }\end{array}$ \\
\hline 2 & 3 & 5 & 2 & $60 \%$ & BAJO \\
\hline
\end{tabular}




\section{Metaproblema 3: Falta de apropiación de la identidad cultural.}

\section{Objetivo estratégico 3: Contribuir a la apropiación de la identidad cultural del departamento}

\begin{tabular}{|c|c|c|c|}
\hline Indicadores & $\begin{array}{l}\text { Corto plazo } \\
\text { (1 a } 4 \text { años) }\end{array}$ & $\begin{array}{l}\text { Mediano plazo } \\
\text { (5 a } 8 \text { años) }\end{array}$ & $\begin{array}{l}\text { Largo plazo } \\
(9 \text { a } 10 \text { años) }\end{array}$ \\
\hline \multirow[t]{6}{*}{$\begin{array}{l}\% \text { de proyectos y } \\
\text { programas para la } \\
\text { apropiación de la } \\
\text { identidad cultural }\end{array}$} & $\begin{array}{l}\text { Promover entre } \\
\text { los proyectos y } \\
\text { programas la } \\
\text { apropiación de la } \\
\text { identidad cultural } \\
\text { del departamento. }\end{array}$ & $\begin{array}{l}\text { Promover entre } \\
\text { los proyectos y } \\
\text { programas la } \\
\text { apropiación de la } \\
\text { identidad cultural } \\
\text { del departamento. }\end{array}$ & $\begin{array}{l}\text { Promover entre } \\
\text { los proyectos y } \\
\text { programas la } \\
\text { apropiación de la } \\
\text { identidad cultural del } \\
\text { departamento. }\end{array}$ \\
\hline & $\begin{array}{l}\text { Propiciar la } \\
\text { ejecución de } \\
\text { investigaciones } \\
\text { socioculturales en } \\
\text { el departamento, } \\
\text { privilegiando } \\
\text { metodologías } \\
\text { de investigación } \\
\text { acción }\end{array}$ & $\begin{array}{l}\text { Propiciar la } \\
\text { ejecución de } \\
\text { investigaciones } \\
\text { socioculturales en } \\
\text { el departamento, } \\
\text { privilegiando } \\
\text { metodologías de } \\
\text { investigación acción } \\
\text { participativa. }\end{array}$ & $\begin{array}{l}\text { Propiciar la ejecución } \\
\text { de investigaciones } \\
\text { socioculturales en } \\
\text { el departamento, } \\
\text { privilegiando } \\
\text { metodologías de } \\
\text { investigación acción } \\
\text { participativa. }\end{array}$ \\
\hline & $\begin{array}{l}\text { participativa con } \\
\text { enfoque diferencial } \\
\text { e inclusivo (étnicas } \\
\text { y población } \\
\text { diversamente } \\
\text { hábil). }\end{array}$ & $\begin{array}{l}\text { Publicar y divulgar } \\
\text { los resultados de } \\
\text { las investigaciones } \\
\text { para apropiar la } \\
\text { identidad tanto } \\
\text { municipal como }\end{array}$ & $\begin{array}{l}\text { Publicar y divulgar } \\
\text { los resultados de las } \\
\text { investigaciones para } \\
\text { apropiar la identidad } \\
\text { tanto municipal como } \\
\text { departamental. }\end{array}$ \\
\hline & $\begin{array}{l}\text { Publicar y divulgar } \\
\text { los resultados de }\end{array}$ & departamental. & $\begin{array}{l}\text { Contribuir al } \\
\text { desarrollo de }\end{array}$ \\
\hline & $\begin{array}{l}\text { las investigaciones } \\
\text { para apropiar la } \\
\text { identidad tanto } \\
\text { municipal como } \\
\text { departamental }\end{array}$ & $\begin{array}{l}\text { Propiciar la } \\
\text { creación de } \\
\text { una división de } \\
\text { publicaciones a } \\
\text { nivel departamental } \\
\text { que se encargue del }\end{array}$ & $\begin{array}{l}\text { la división de } \\
\text { publicaciones a } \\
\text { nivel departamental } \\
\text { que se encarga del } \\
\text { proceso editorial, } \\
\text { de publicación y }\end{array}$ \\
\hline & $\begin{array}{l}\text { Promover la } \\
\text { realización y } \\
\text { actualización del }\end{array}$ & $\begin{array}{l}\text { proceso editorial, } \\
\text { de publicación y de } \\
\text { divulgación de }\end{array}$ & $\begin{array}{l}\text { de divulgación de } \\
\text { los resultados de } \\
\text { investigación y de }\end{array}$ \\
\hline
\end{tabular}




\begin{tabular}{|c|c|c|c|}
\hline Indicadores & $\begin{array}{l}\text { Corto plazo } \\
\text { (1 a } 4 \text { años) }\end{array}$ & $\begin{array}{l}\text { Mediano plazo } \\
\text { (5 a } 8 \text { años) }\end{array}$ & $\begin{array}{l}\text { Largo plazo } \\
(9 \text { a } 10 \text { años })\end{array}$ \\
\hline & $\begin{array}{l}\text { inventario cultural } \\
\text { del departamento. } \\
\text { Facilitar un } \\
\text { tránsito activo } \\
\text { entre los sectores, } \\
\text { de manera que se } \\
\text { vean beneficiados } \\
\text { quienes participen } \\
\text { en las actividades } \\
\text { culturales y } \\
\text { sectoriales. }\end{array}$ & $\begin{array}{l}\text { los resultados de } \\
\text { investigación y de } \\
\text { creación artística y } \\
\text { cultural. } \\
\text { Establecer y } \\
\text { ejecutar estrategias } \\
\text { de preservación y } \\
\text { apropiación de la } \\
\text { identidad cultural } \\
\text { del departamento, } \\
\text { permitiendo } \\
\text { conservar un status } \\
\text { identitario. } \\
\text { Generar rutas de } \\
\text { exploración cultural } \\
\text { entre los municipios. } \\
\text { Facilitar un } \\
\text { tránsito activo } \\
\text { entre los sectores, } \\
\text { de manera que se } \\
\text { vean beneficiados } \\
\text { quienes participen } \\
\text { en las actividades } \\
\text { culturales y } \\
\text { sectoriales. }\end{array}$ & $\begin{array}{l}\text { creación artística y } \\
\text { cultural. } \\
\text { Divulgar los } \\
\text { resultados de las } \\
\text { investigaciones para } \\
\text { apropiar la identidad } \\
\text { tanto municipal como } \\
\text { departamental. } \\
\text { Evaluar y modificar } \\
\text { las estrategias de } \\
\text { apropiación y } \\
\text { preservación de la } \\
\text { identidad cultural } \\
\text { aplicada en las } \\
\text { administraciones } \\
\text { anteriores. }\end{array}$ \\
\hline
\end{tabular}

\begin{tabular}{|c|c|c|c|c|c|}
\hline $\begin{array}{c}\text { SIMPLICIDAD } \\
\text { (sencillez para } \\
\text { su adopción) }\end{array}$ & $\begin{array}{c}\text { VIABILIDAD } \\
\text { ADMINISTRATIVA } \\
\text { (capacidad } \\
\text { administrativa, de } \\
\text { recursos humanos y } \\
\text { técnicos) }\end{array}$ & $\begin{array}{l}\text { VIABILIDAD } \\
\text { POLÍ́TICA } \\
\text { (popularidad de } \\
\text { la alternativa) }\end{array}$ & $\begin{array}{c}\text { VIABILIDAD } \\
\text { ECONÓMICA } \\
\text { (¿se cuenta con } \\
\text { los recursos?) }\end{array}$ & $\begin{array}{c}\% \text { DE } \\
\text { VIABILIDAD }\end{array}$ & $\begin{array}{c}\text { IMPACTO } \\
\text { AMBIENTAL }\end{array}$ \\
\hline 5 & 4 & 5 & 2 & $80 \%$ & BAJO \\
\hline
\end{tabular}




\section{Metaproblema 4: Falta de infraestructura adecuada y suficiente.}

\section{Objetivo estratégico 4: Generar proyectos para mejorary adecuar de infraestructura suficiente y sostenible a cada uno de los municipios.}

\begin{tabular}{|c|c|c|c|}
\hline Indicadores & $\begin{array}{l}\text { Corto plazo } \\
\text { (1 a } 4 \text { años) }\end{array}$ & $\begin{array}{l}\text { Mediano plazo } \\
\text { (5 a } 8 \text { años) }\end{array}$ & $\begin{array}{l}\text { Largo plazo } \\
(9 \text { a } 10 \text { años) }\end{array}$ \\
\hline $\begin{array}{l}\% \text { de } \\
\text { infraestructura } \\
\text { construida, } \\
\text { adecuada, } \\
\text { acondicionada, } \\
\text { mantenida o } \\
\text { remodelada por } \\
\text { municipio } \\
\% \text { de número de } \\
\text { metros cuadrados } \\
\text { de infraestructura } \\
\text { cultural en función } \\
\text { de la población } \\
\text { total por municipio } \\
\text { \% de } \\
\text { infraestructura } \\
\text { cultural sostenible } \\
\text { por municipio }\end{array}$ & $\begin{array}{l}\text { Determinar } \\
\text { el número de } \\
\text { escenarios } \\
\text { destinados a } \\
\text { la cultura por } \\
\text { municipio } \\
\\
\text { Determinar } \\
\text { el estado de } \\
\text { los escenarios } \\
\text { existentes } \\
\text { destinados a } \\
\text { la cultura por } \\
\text { municipio } \\
\\
\text { Establecer las } \\
\text { necesidades de } \\
\text { infraestructura en } \\
\text { función de variables } \\
\text { sociales y culturales } \\
\text { (tamaño de } \\
\text { población, número } \\
\text { de actividades y } \\
\text { manifestaciones } \\
\text { que necesitan } \\
\text { espacio, número de } \\
\text { cultores, etc.). } \\
\text { Adecuar y restaurar } \\
\text { el Palacio San } \\
\text { Francisco, en } \\
\text { Bogotá, como } \\
\text { sede cultural del } \\
\text { departamento. }\end{array}$ & $\begin{array}{l}\text { Asegurar el } \\
\text { mantenimiento } \\
\text { del Palacio San } \\
\text { Francisco, en } \\
\text { Bogotá, como } \\
\text { sede cultural del } \\
\text { departamento. } \\
\text { Construir, } \\
\text { adecuar, ampliar } \\
\text { o acondicionar } \\
\text { espacios para } \\
\text { el desarrollo } \\
\text { de actividades } \\
\text { culturales por } \\
\text { municipio }\end{array}$ & $\begin{array}{l}\text { Establecer las } \\
\text { necesidades de } \\
\text { infraestructura } \\
\text { en función de } \\
\text { variables sociales y } \\
\text { culturales (tamaño de } \\
\text { población, número } \\
\text { de actividades y } \\
\text { manifestaciones que } \\
\text { necesitan espacio, } \\
\text { número de cultores, } \\
\text { etc.) } \\
\text { Asegurar el } \\
\text { mantenimiento } \\
\text { del Palacio San } \\
\text { Francisco, en Bogotá, } \\
\text { como sede cultural } \\
\text { del departamento. } \\
\text { Construir, } \\
\text { adecuar, ampliar o } \\
\text { acondicionar espacios } \\
\text { para el desarrollo de } \\
\text { actividades culturales } \\
\text { por municipio con } \\
\text { cumplimiento de } \\
\text { estándares mínimos } \\
\text { Mantener o } \\
\text { remodelar espacios } \\
\text { para el desarrollo de } \\
\text { actividades culturales }\end{array}$ \\
\hline
\end{tabular}




\begin{tabular}{|c|c|c|c|}
\hline Indicadores & $\begin{array}{l}\text { Corto plazo } \\
\text { (1 a } 4 \text { años) }\end{array}$ & $\begin{array}{l}\text { Mediano plazo } \\
\text { (5 a } 8 \text { años) }\end{array}$ & $\begin{array}{l}\text { Largo plazo } \\
(9 \text { a } 10 \text { años })\end{array}$ \\
\hline $\begin{array}{l}\text { \% de } \\
\text { infraestructura } \\
\text { construida, } \\
\text { adecuada, } \\
\text { acondicionada, } \\
\text { mantenida o } \\
\text { remodelada por } \\
\text { municipio } \\
\text { \% de número de } \\
\text { metros cuadrados } \\
\text { de infraestructura } \\
\text { cultural en función } \\
\text { de la población } \\
\text { total por municipio } \\
\text { \% de } \\
\text { infraestructura } \\
\text { cultural sostenible } \\
\text { por municipio }\end{array}$ & $\begin{array}{l}\text { Construir, } \\
\text { adecuar, ampliar } \\
\text { o acondicionar } \\
\text { espacios para } \\
\text { el desarrollo } \\
\text { de actividades } \\
\text { culturales por } \\
\text { municipio } \\
\text { Mantener o } \\
\text { remodelar espacios } \\
\text { para el desarrollo } \\
\text { de actividades } \\
\text { culturales por } \\
\text { municipio } \\
\text { Determinar e } \\
\text { institucionalizar } \\
\text { estándares } \\
\text { mínimos para } \\
\text { espacios de } \\
\text { desarrollo de } \\
\text { actividades } \\
\text { culturales en el } \\
\text { departamento } \\
\text { Conservar y } \\
\text { preservar los bienes } \\
\text { de interés cultural } \\
\text { Buscar estrategias } \\
\text { para la protección } \\
\text { del patrimonio } \\
\text { material e } \\
\text { inmaterial del } \\
\text { departamento }\end{array}$ & $\begin{array}{l}\text { para el desarrollo } \\
\text { de actividades } \\
\text { culturales por } \\
\text { municipio } \\
\text { Determinar estado } \\
\text { de sostenibilidad } \\
\text { financiera y } \\
\text { ambiental de } \\
\text { espacios para } \\
\text { el desarrollo } \\
\text { de actividades } \\
\text { culturales por } \\
\text { municipio } \\
\text { y establecer } \\
\text { lineamientos } \\
\text { Conservar y } \\
\text { preservar los bienes } \\
\text { de interés cultural } \\
\text { Implementar las } \\
\text { estrategias para } \\
\text { la protección } \\
\text { del patrimonio } \\
\text { material e } \\
\text { inmaterial del } \\
\text { departamento }\end{array}$ & $\begin{array}{l}\text { por municipio con } \\
\text { cumplimiento de } \\
\text { estándares mínimos } \\
\text { Garantizar la } \\
\text { sostenibilidad } \\
\text { financiera y } \\
\text { ambiental de espacios } \\
\text { para el desarrollo de } \\
\text { actividades culturales } \\
\text { por municipio } \\
\text { y establecer } \\
\text { lineamientos } \\
\text { Conservar y preservar } \\
\text { los bienes de interés } \\
\text { cultural }\end{array}$ \\
\hline
\end{tabular}




\begin{tabular}{|c|c|c|c|c|c|}
\hline $\begin{array}{c}\text { SIMPLICIDAD } \\
\text { (sencillez para } \\
\text { su adopción) }\end{array}$ & $\begin{array}{c}\text { VIABILIDAD } \\
\text { ADMINISTRATIVA } \\
\text { (capacidad } \\
\text { administrativa, de } \\
\text { recursos humanos y } \\
\text { técnicos) }\end{array}$ & $\begin{array}{l}\text { VIABILIDAD } \\
\text { POLÍTICA } \\
\text { (popularidad de } \\
\text { la alternativa) }\end{array}$ & $\begin{array}{c}\text { VIABILIDAD } \\
\text { ECONÓMICA } \\
\text { ('se cuenta con } \\
\text { los recursos?) }\end{array}$ & $\begin{array}{c}\% \text { DE } \\
\text { VIABILIDAD }\end{array}$ & $\begin{array}{c}\text { IMPACTO } \\
\text { AMBIENTAL }\end{array}$ \\
\hline 2 & 3 & 5 & 2 & $60 \%$ & ALTO \\
\hline
\end{tabular}

\section{Metaproblema 5: Baja articulación tanto entre actores e institu- ciones del sistema como con otros sectores.}

\section{Objetivo estratégico 5: Promover la articulación entre los actores y demás instancias del sistema, así como con otros sectores.}

\begin{tabular}{|c|c|c|c|}
\hline Indicadores & $\begin{array}{l}\text { Corto plazo } \\
\text { (1 a } 4 \text { años) }\end{array}$ & $\begin{array}{l}\text { Mediano plazo } \\
\text { (5 a } 8 \text { años) }\end{array}$ & $\begin{array}{l}\text { Largo plazo } \\
(9 \text { a } 10 \text { años) }\end{array}$ \\
\hline $\begin{array}{l}\text { \% de proyectos } \\
\text { y programas } \\
\text { ejecutados entre } \\
\text { instancias del } \\
\text { sector } \\
\text { \% de proyectos } \\
\text { y programas } \\
\text { ejecutados con } \\
\text { otros sectores } \\
\text { \% de proyectos } \\
\text { por línea artística o } \\
\text { subsector cultural e } \\
\text { relación al número } \\
\text { total de proyectos } \\
\text { por municipio y } \\
\text { departamento }\end{array}$ & $\begin{array}{l}\text { Promover y } \\
\text { facilitar el } \\
\text { funcionamiento } \\
\text { de los Consejos } \\
\text { municipales y } \\
\text { departamentales } \\
\text { de cultura } \\
\text { como órgano } \\
\text { participativo } \\
\text { del Sistema } \\
\text { Departamental de } \\
\text { Cultura (SDG) } \\
\text { Formular } \\
\text { estrategias } \\
\text { de diseño y } \\
\text { formulación } \\
\text { de proyectos y } \\
\text { programas entre } \\
\text { las instancias e } \\
\text { instituciones } \\
\text { departamentales, a } \\
\text { saber: secretaría }\end{array}$ & $\begin{array}{l}\text { Promover y } \\
\text { facilitar el } \\
\text { funcionamiento } \\
\text { de los Consejos } \\
\text { municipales y } \\
\text { departamentales } \\
\text { de cultura } \\
\text { como órgano } \\
\text { participativo } \\
\text { del Sistema } \\
\text { Departamental de } \\
\text { Cultura (SDC) } \\
\text { Mantener la } \\
\text { participación de } \\
\text { otros sectores en } \\
\text { pro de la gestión } \\
\text { cultural. } \\
\text { Propiciar el de } \\
\text { diseño y } \\
\text { formulación de } \\
\text { proyectos y }\end{array}$ & $\begin{array}{l}\text { Promover y facilitar el } \\
\text { funcionamiento de los } \\
\text { Consejos municipales } \\
\text { y departamentales } \\
\text { de cultura como } \\
\text { órgano participativo } \\
\text { del Sistema } \\
\text { Departamental de } \\
\text { Cultura (SDG) } \\
\text { Propiciar el de diseño } \\
\text { y formulación de } \\
\text { proyectos y programas } \\
\text { entre las instancias } \\
\text { e instituciones } \\
\text { departamentales., a } \\
\text { saber: secretaría de } \\
\text { educación, deporte, } \\
\text { desarrollo social, } \\
\text { planeación, salud, } \\
\text { entre otras. }\end{array}$ \\
\hline
\end{tabular}




\begin{tabular}{|c|c|c|c|}
\hline Indicadores & $\begin{array}{l}\text { Corto plazo } \\
\text { (1 a } 4 \text { años) }\end{array}$ & $\begin{array}{l}\text { Mediano plazo } \\
\text { (5 a } 8 \text { años) }\end{array}$ & $\begin{array}{l}\text { Largo plazo } \\
(9 \text { a } 10 \text { años })\end{array}$ \\
\hline & $\begin{array}{l}\text { de educación, } \\
\text { deporte, desarrollo } \\
\text { social, planeación, } \\
\text { salud, entre otras } \\
\text { Aumentar la } \\
\text { vinculación de } \\
\text { otros sectores } \\
\text { que promuevan y } \\
\text { faciliten la gestión } \\
\text { cultural }\end{array}$ & $\begin{array}{l}\text { programas entre } \\
\text { las instancias } \\
\text { e instituciones } \\
\text { departamentales, } \\
\text { a saber: secretaría } \\
\text { de educación, } \\
\text { deporte, desarrollo } \\
\text { social, planeación, } \\
\text { salud, entre otras. } \\
\text { Facilitar un } \\
\text { tránsito activo } \\
\text { entre los sectores, } \\
\text { de manera que se } \\
\text { vean beneficiados } \\
\text { quienes participen } \\
\text { en las actividades } \\
\text { culturales y } \\
\text { sectoriales. }\end{array}$ & $\begin{array}{l}\text { Garantizar una } \\
\text { alta vinculación y } \\
\text { colaboración entre los } \\
\text { sectores de manera } \\
\text { que sea necesaria la } \\
\text { participación para un } \\
\text { rendimiento exitoso } \\
\text { de la labor cultural. } \\
\text { Revisar la ejecución } \\
\text { de las anteriores } \\
\text { administraciones } \\
\text { para generar nuevos } \\
\text { insumos y estrategias } \\
\text { de articulación }\end{array}$ \\
\hline
\end{tabular}

\begin{tabular}{|c|c|c|c|c|c|}
\hline $\begin{array}{c}\text { SIMPLICIDAD } \\
\text { (sencillez para } \\
\text { su adopción) }\end{array}$ & $\begin{array}{c}\text { VIABILIDAD } \\
\text { ADMINISTRATIVA } \\
\text { (capacidad } \\
\text { administrativa, de } \\
\text { recursos humanos y } \\
\text { técnicos) }\end{array}$ & $\begin{array}{c}\text { VIABILIDAD } \\
\text { POLÍTICA } \\
\text { (popularidad de } \\
\text { la alternativa) }\end{array}$ & $\begin{array}{l}\text { VIABILIDAD } \\
\text { ECONÓMICA } \\
\text { (¿se cuenta con } \\
\text { los recursos?) }\end{array}$ & $\begin{array}{c}\% \text { DE } \\
\text { VIABILIDAD }\end{array}$ & $\begin{array}{c}\text { IMPACTO } \\
\text { AMBIENTAL }\end{array}$ \\
\hline 4 & 5 & 4 & 4 & $85 \%$ & BAJO \\
\hline
\end{tabular}




\section{Metaproblema 6: Falta de gestión y de alcance institucional}

\section{Objetivo estratégico 6: Propiciar el desarrollo institucional del IDECUT y de las demás instancias municipales encargadas de la cultura.}

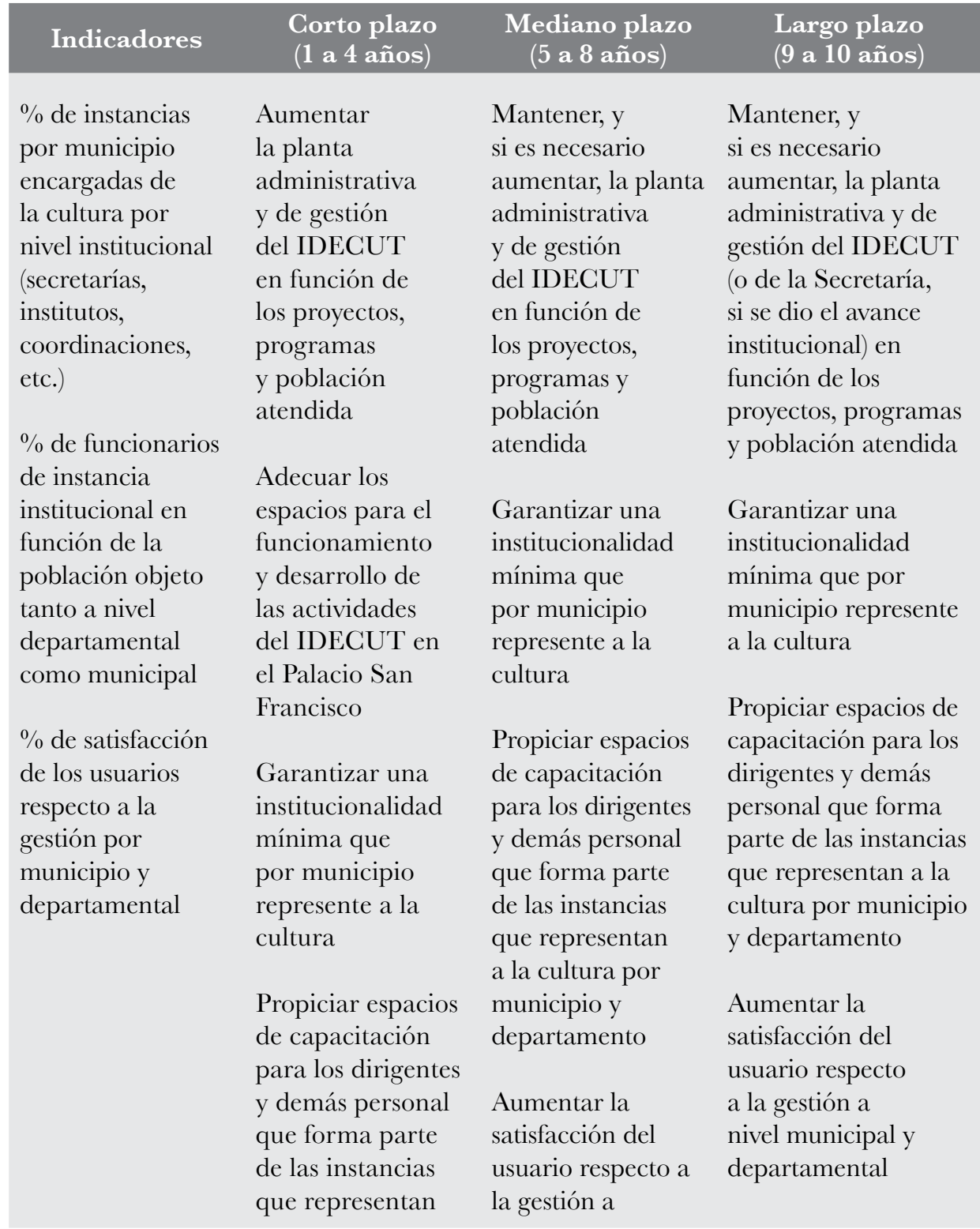




\begin{tabular}{|c|c|c|c|}
\hline Indicadores & $\begin{array}{l}\text { Corto plazo } \\
\text { (1 a } 4 \text { años) }\end{array}$ & $\begin{array}{l}\text { Mediano plazo } \\
\text { (5 a } 8 \text { años) }\end{array}$ & $\begin{array}{l}\text { Largo plazo } \\
\text { (9 a } 10 \text { años) }\end{array}$ \\
\hline & $\begin{array}{l}\text { a la cultura por } \\
\text { municipio y } \\
\text { y departamento } \\
\text { Aumentar la } \\
\text { satisfacción del } \\
\text { usuario respecto } \\
\text { a la gestión a } \\
\text { nivel municipal y } \\
\text { departamental } \\
\text { Iniciar estudios } \\
\text { técnicos para } \\
\text { propiciar un } \\
\text { desarrollo y } \\
\text { reconocimiento } \\
\text { del sector cultura } \\
\text { como un Instituto } \\
\text { independiente y } \\
\text { autónomo } \\
\text { Crear mecanismos } \\
\text { de seguimiento que } \\
\text { permitan validar } \\
\text { el cumplimiento } \\
\text { de las normativas } \\
\text { existentes en torno } \\
\text { a la cultura }\end{array}$ & $\begin{array}{l}\text { nivel municipal y } \\
\text { departamental } \\
\text { Institucionalizar } \\
\text { al sector cultura } \\
\text { como un Instituto } \\
\text { independiente y } \\
\text { autónomo } \\
\text { Crear mecanismos } \\
\text { de seguimiento que } \\
\text { permitan validar } \\
\text { el cumplimiento } \\
\text { de las normativas } \\
\text { existentes en torno } \\
\text { a la cultura } \\
\text { Implementar } \\
\text { proyectos y } \\
\text { programas de } \\
\text { estímulos e } \\
\text { incentivos. }\end{array}$ & $\begin{array}{l}\text { Crear mecanismos } \\
\text { de seguimiento que } \\
\text { permitan validar el } \\
\text { cumplimiento de las } \\
\text { normativas existentes } \\
\text { en torno a la cultura } \\
\text { Implementar } \\
\text { proyectos y } \\
\text { programas de } \\
\text { estímulos e incentivos. }\end{array}$ \\
\hline & $\begin{array}{l}\text { Establecer } \\
\text { articulación en } \\
\text { el desarrollo de } \\
\text { planes y proyectos } \\
\text { con las entidades } \\
\text { departamentales. } \\
\text { Diseñar proyectos } \\
\text { y programas } \\
\text { de estímulos e } \\
\text { incentivos. }\end{array}$ & & \\
\hline
\end{tabular}




\begin{tabular}{|c|c|c|c|c|c|}
\hline $\begin{array}{c}\text { SIMPLICIDAD } \\
\text { (sencillez para } \\
\text { su adopción) }\end{array}$ & $\begin{array}{c}\text { VIABILIDAD } \\
\text { ADMINISTRATIVA } \\
\text { (capacidad } \\
\text { administrativa, de } \\
\text { recursos humanos y } \\
\text { técnicos) }\end{array}$ & $\begin{array}{l}\text { VIABILIDAD } \\
\text { POLÍTICA } \\
\text { (popularidad de } \\
\text { la alternativa) }\end{array}$ & $\begin{array}{c}\text { VIABILIDAD } \\
\text { ECONÓMICA } \\
\text { (¿se cuenta con } \\
\text { los recursos?) }\end{array}$ & $\begin{array}{c}\% \text { DE } \\
\text { VIABILIDAD }\end{array}$ & $\begin{array}{c}\text { IMPACTO } \\
\text { AMBIENTAL }\end{array}$ \\
\hline 4 & 3 & 3 & 3 & $65 \%$ & MEDIO \\
\hline
\end{tabular}

Metaproblema 7: Baja información, comunicación y divulgación tanto de la oferta cultural como entre los actores e instituciones del SDG.

Objetivo estratégico 7: Contribuir al mejoramiento de medios y canales de información para la divulgación tanto de la oferta como de la circulación de los productos culturales.

\begin{tabular}{|c|c|c|c|}
\hline Indicadores & $\begin{array}{l}\text { Corto plazo } \\
\text { (1 a } 4 \text { años) }\end{array}$ & $\begin{array}{l}\text { Mediano plazo } \\
\text { (5 a } 8 \text { años })\end{array}$ & $\begin{array}{l}\text { Largo plazo } \\
(9 \text { a } 10 \text { años) }\end{array}$ \\
\hline $\begin{array}{l}\text { \% de medios de } \\
\text { comunicación } \\
\text { disponibles en } \\
\text { función de la } \\
\text { población objeto } \\
\text { por municipio } \\
\text { \% de estado de } \\
\text { implementación } \\
\text { y ejecución de } \\
\text { proyecto para } \\
\text { la recolección } \\
\text { y análisis de } \\
\text { información sobre } \\
\text { el sector en el } \\
\text { departamento }\end{array}$ & $\begin{array}{l}\text { Establecer } \\
\text { mecanismos de } \\
\text { comunicación } \\
\text { activa. } \\
\text { Implementar } \\
\text { medios de } \\
\text { comunicación y } \\
\text { publicación de } \\
\text { la oferta cultural } \\
\text { (impresa y virtual). } \\
\text { Establecer } \\
\text { una batería de } \\
\text { indicadores que } \\
\text { reflejen la realidad } \\
\text { de la cultura en } \\
\text { el departamento } \\
\text { para la toma de } \\
\text { decisiones. }\end{array}$ & $\begin{array}{l}\text { Recopilar, } \\
\text { analizar y evaluar } \\
\text { la información } \\
\text { obtenida de } \\
\text { la batería de } \\
\text { indicadores para la } \\
\text { toma de decisiones. }\end{array}$ & $\begin{array}{l}\text { Implementar medios } \\
\text { de comunicación } \\
\text { y publicación de } \\
\text { la oferta cultural } \\
\text { (impresa y virtual). } \\
\text { Recopilar, analizar } \\
\text { y evaluar la } \\
\text { información } \\
\text { obtenida de la } \\
\text { batería de indicadores } \\
\text { para la toma de } \\
\text { decisiones. } \\
\text { Implementar } \\
\text { estrategias de } \\
\text { adopción de las } \\
\text { TIC como canal } \\
\text { para la difusión y } \\
\text { divulgación de la } \\
\text { cultura. }\end{array}$ \\
\hline
\end{tabular}




\begin{tabular}{|c|c|c|c|}
\hline Indicadores & $\begin{array}{l}\text { Corto plazo } \\
\text { (1 a } 4 \text { años })\end{array}$ & $\begin{array}{l}\text { Mediano plazo } \\
\text { (5 a } 8 \text { años) }\end{array}$ & $\begin{array}{l}\text { Largo plazo } \\
(9 \text { a } 10 \text { años })\end{array}$ \\
\hline $\begin{array}{l}\text { \% de canales } \\
\text { de circulación } \\
\text { dispuestos e } \\
\text { interconectados en } \\
\text { el departamento } \\
\text { \% de personas } \\
\text { que acceden tanto } \\
\text { a la oferta como } \\
\text { a los canales } \\
\text { de circulación } \\
\text { cultural a través de } \\
\text { diversos medios de } \\
\text { comunicación }\end{array}$ & $\begin{array}{l}\text { Diseñar estrategias } \\
\text { de implementación } \\
\text { de las TIC } \\
\text { como canal para } \\
\text { la difusión y } \\
\text { divulgación de la } \\
\text { cultura. } \\
\text { Evaluar los } \\
\text { actuales canales } \\
\text { de circulación } \\
\text { de los productos } \\
\text { culturales en todo } \\
\text { el departamento, } \\
\text { para determinar } \\
\text { su viabilidad } \\
\text { y opciones de } \\
\text { mejora. }\end{array}$ & $\begin{array}{l}\text { divulgación de la } \\
\text { cultura. } \\
\text { Fortalecer y } \\
\text { desarrollar } \\
\text { los canales de } \\
\text { circulación de } \\
\text { los productos } \\
\text { culturales en todo } \\
\text { el departamento. } \\
\text { Establecer } \\
\text { articulación en } \\
\text { el desarrollo de } \\
\text { planes y proyectos } \\
\text { con las entidades } \\
\text { departamentales. }\end{array}$ & $\begin{array}{l}\text { Fortalecer y } \\
\text { desarrollar los } \\
\text { canales de circulación } \\
\text { de los productos } \\
\text { culturales en todo el } \\
\text { departamento. } \\
\text { Evaluar las } \\
\text { estrategias diseñadas } \\
\text { e implementadas } \\
\text { en las anteriores } \\
\text { administraciones } \\
\text { para generar } \\
\text { nuevos medios de } \\
\text { divulgación de la } \\
\text { oferta cultural. } \\
\text { Establecer } \\
\text { articulación en } \\
\text { el desarrollo de } \\
\text { planes y proyectos } \\
\text { con las entidades } \\
\text { departamentales. }\end{array}$ \\
\hline
\end{tabular}

\begin{tabular}{|c|c|c|c|c|c|}
\hline $\begin{array}{c}\text { SIMPLICIDAD } \\
\text { (sencillez para } \\
\text { su adopción) }\end{array}$ & $\begin{array}{c}\text { VIABILIDAD } \\
\text { ADMINISTRATIVA } \\
\text { (capacidad } \\
\text { administrativa, de } \\
\text { recursos humanos y } \\
\text { técnicos) }\end{array}$ & $\begin{array}{l}\text { VIABILIDAD } \\
\text { POLITICA } \\
\text { (popularidad de } \\
\text { la alternativa) }\end{array}$ & $\begin{array}{l}\text { VIABILIDAD } \\
\text { ECONÓMICA } \\
\text { (¿se cuenta con } \\
\text { los recursos?) }\end{array}$ & $\begin{array}{c}\% \text { DE } \\
\text { VIABILIDAD }\end{array}$ & $\begin{array}{c}\text { IMPACTO } \\
\text { AMBIENTAL }\end{array}$ \\
\hline 4 & 3 & 3 & 3 & $65 \%$ & BAJO \\
\hline
\end{tabular}




\section{Metaproblema 8: Bajo nivel de formación y de generación de cono- cimiento (educación e investigación).}

Objetivo estratégico 8: Facilitar mecanismos de capacitación a través de incentivos y ejecución de proyectos culturales en el departamento.

\begin{tabular}{|c|c|c|c|}
\hline Indicadores & $\begin{array}{l}\text { Corto plazo } \\
\text { (1 a } 4 \text { años) }\end{array}$ & $\begin{array}{l}\text { Mediano plazo } \\
\text { (5 a } 8 \text { años) }\end{array}$ & $\begin{array}{l}\text { Largo plazo } \\
(9 \text { a } 10 \text { años })\end{array}$ \\
\hline $\begin{array}{l}\text { capacitadas sobre } \\
\text { el número total } \\
\text { de formadores } \\
\text { culturales del } \\
\text { departamento } \\
\text { \% de proyectos } \\
\text { y programas } \\
\text { de estímulos } \\
\text { e incentivos } \\
\text { ejecutados por } \\
\text { municipio } \\
\text { \% de proyectos de } \\
\mathrm{i}+\mathrm{d}+\mathrm{i} \text { ejecutados } \\
\text { por municipio }\end{array}$ & $\begin{array}{l}\text { Evaluar los } \\
\text { existentes } \\
\text { mecanismos de } \\
\text { formación. } \\
\text { Establecer mínimos } \\
\text { aptitudinales para } \\
\text { ocupar los cargos } \\
\text { de formadores y } \\
\text { gestores culturales. }\end{array}$ & $\begin{array}{l}\text { Implementar } \\
\text { proyectos y } \\
\text { programas de } \\
\text { estímulos e } \\
\text { incentivos. } \\
\text { Implementar } \\
\text { programas para } \\
\text { educación no } \\
\text { formal. } \\
\text { Implementar } \\
\text { proyectos y } \\
\text { programas de. }\end{array}$ & $\begin{array}{l}\text { Implementar } \\
\text { proyectos y } \\
\text { programas de } \\
\text { formación para el } \\
\text { público que accede a } \\
\text { la cultura. } \\
\text { Establecer las } \\
\text { necesidades a nivel } \\
\text { de formación por } \\
\text { municipio y por } \\
\text { subsector }\end{array}$ \\
\hline
\end{tabular}




\begin{tabular}{|c|c|c|c|}
\hline Indicadores & $\begin{array}{l}\text { Corto plazo } \\
\text { (1 a } 4 \text { años) }\end{array}$ & $\begin{array}{l}\text { Mediano plazo } \\
\text { (5 a } 8 \text { años) }\end{array}$ & $\begin{array}{l}\text { Largo plazo } \\
(9 \text { a } 10 \text { años) }\end{array}$ \\
\hline $\begin{array}{l}\text { \% de alianzas } \\
\text { público-privadas } \\
\text { para formación }\end{array}$ & $\begin{array}{l}\text { Diseñar proyectos } \\
\text { y programas de } \\
\text { formación para el } \\
\text { público que accede } \\
\text { a la cultura } \\
\text { Establecer las } \\
\text { necesidades a nivel } \\
\text { de formación por } \\
\text { municipio y por } \\
\text { subsector } \\
\text { Propiciar el } \\
\text { establecimiento de } \\
\text { APP para procesos } \\
\text { de formación. } \\
\text { Promover la } \\
\text { capacitación a la } \\
\text { población para } \\
\text { la gestión de } \\
\text { proyectos } \\
\text { Generar espacios } \\
\text { de creación de } \\
\text { proyectos propios. }\end{array}$ & $\begin{array}{l}\text { formación para el } \\
\text { público que accede } \\
\text { a la cultura } \\
\text { Establecer las } \\
\text { necesidades a nivel } \\
\text { de formación por } \\
\text { municipio y por } \\
\text { subsector } \\
\text { Propiciar el } \\
\text { establecimiento de } \\
\text { APP para procesos } \\
\text { de formación. } \\
\text { Diseñar proyectos } \\
\text { de Investigación y } \\
\text { Desarrollo sobre } \\
\text { temas culturales. }\end{array}$ & $\begin{array}{l}\text { Propiciar el } \\
\text { establecimiento de } \\
\text { APP para procesos de } \\
\text { formación. } \\
\text { Diseñar proyectos } \\
\text { de Investigación y } \\
\text { Desarrollo sobre } \\
\text { temas culturales. } \\
\text { Aumentar el } \\
\text { porcentaje de } \\
\text { formadores y gestores } \\
\text { culturales con } \\
\text { formación profesional } \\
\text { sobre el área }\end{array}$ \\
\hline
\end{tabular}

\begin{tabular}{|c|c|c|c|c|c|}
\hline $\begin{array}{c}\text { SIMPLICIDAD } \\
\text { (sencillez para } \\
\text { su adopción) }\end{array}$ & $\begin{array}{c}\text { VIABILIDAD } \\
\text { ADMINISTRATIVA } \\
\text { (capacidad } \\
\text { administrativa, de } \\
\text { recursos humanos y } \\
\text { técnicos) }\end{array}$ & $\begin{array}{l}\text { VIABILIDAD } \\
\text { POLÍTICA } \\
\text { (popularidad de } \\
\text { la alternativa) }\end{array}$ & $\begin{array}{l}\text { VIABILIDAD } \\
\text { ECONÓMICA } \\
\text { (ise cuenta con } \\
\text { los recursos?) }\end{array}$ & $\begin{array}{c}\text { \% DE } \\
\text { VIABILIDAD }\end{array}$ & $\begin{array}{c}\text { IMPACTO } \\
\text { AMBIENTAL }\end{array}$ \\
\hline 3 & 4 & 5 & 2 & $70 \%$ & BAJO \\
\hline
\end{tabular}




\section{Metaproblema 9: Baja cobertura y acceso de la población a los programas y proyectos.}

Objetivo estratégico 9: Aumentarla coberturay acceso de la población a los programas y proyectos, dando prioridad al reconocimiento de las manifestaciones culturales en el marco de la diversidad.

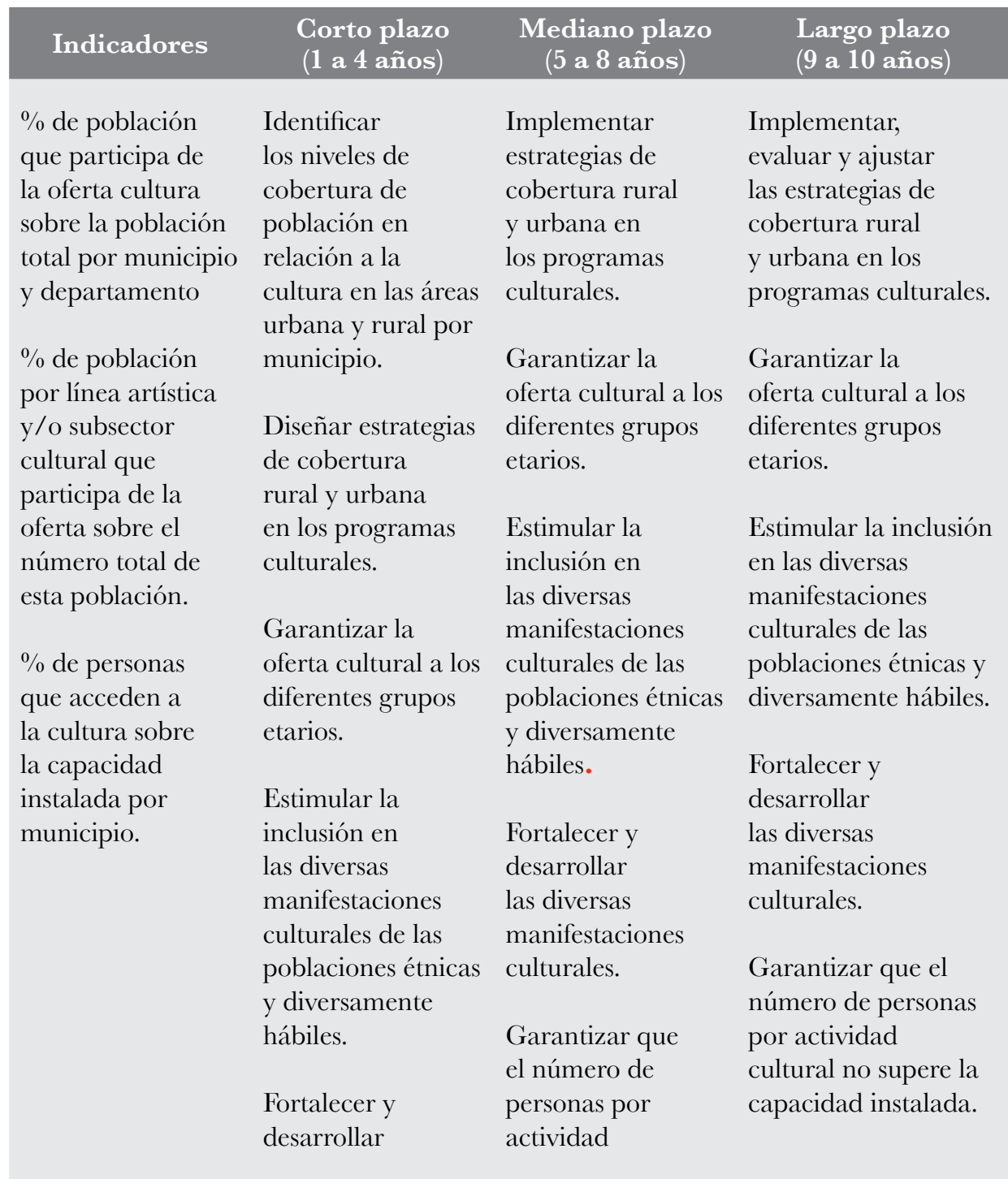




\begin{tabular}{|c|c|c|c|}
\hline Indicadores & $\begin{array}{l}\text { Corto plazo } \\
\text { (1 a } 4 \text { años })\end{array}$ & $\begin{array}{l}\text { Mediano plazo } \\
\text { (5 a } 8 \text { años) }\end{array}$ & $\begin{array}{l}\text { Largo plazo } \\
(9 \text { a } 10 \text { años })\end{array}$ \\
\hline & $\begin{array}{l}\text { las diversas } \\
\text { manifestaciones } \\
\text { culturales } \\
\text { Establecer la } \\
\text { capacidad instalada } \\
\text { para actividades } \\
\text { culturales por } \\
\text { municipio. } \\
\text { Aumentar } \\
\text { progresivamente } \\
\text { la participación de } \\
\text { la ciudadanía en } \\
\text { los programas y } \\
\text { proyectos } \\
\text { culturales del } \\
\text { departamento. }\end{array}$ & $\begin{array}{l}\text { cultural no supere } \\
\text { la capacidad } \\
\text { instalada. } \\
\text { Aumentar } \\
\text { progresivamente } \\
\text { la participación } \\
\text { de la ciudadanía } \\
\text { en los programas } \\
\text { y proyectos } \\
\text { culturales del } \\
\text { departamento. }\end{array}$ & $\begin{array}{l}\text { Aumentar } \\
\text { progresivamente } \\
\text { la participación de } \\
\text { la ciudadanía en } \\
\text { los programas y } \\
\text { proyectos culturales } \\
\text { del departamento. } \\
\text { Evaluar el impacto } \\
\text { y los efectos sobre la } \\
\text { población beneficiada } \\
\text { de las actividades } \\
\text { culturales. }\end{array}$ \\
\hline
\end{tabular}

\begin{tabular}{|c|c|c|c|c|c|}
\hline $\begin{array}{c}\text { SIMPLICIDAD } \\
\text { (sencillez para } \\
\text { su adopción) }\end{array}$ & $\begin{array}{c}\text { VIABILIDAD } \\
\text { ADMINISTRATIVA } \\
\text { (capacidad } \\
\text { administrativa, de } \\
\text { recursos humanos y } \\
\text { técnicos) }\end{array}$ & $\begin{array}{l}\text { VIABILIDAD } \\
\text { POLÍTICA } \\
\text { (popularidad de } \\
\text { la alternativa) }\end{array}$ & $\begin{array}{c}\text { VIABILIDAD } \\
\text { ECONÓMICA } \\
\text { (¿se cuenta con } \\
\text { los recursos?) }\end{array}$ & $\begin{array}{c}\text { \% DE } \\
\text { VIABILIDAD }\end{array}$ & $\begin{array}{c}\text { IMPACTO } \\
\text { AMBIENTAL }\end{array}$ \\
\hline 3 & 3 & 5 & 3 & $70 \%$ & BAJO \\
\hline
\end{tabular}

\section{Institucionalización del Plan Decenal}

A continuación se presenta el borrador de proyecto de Ordenanza para adoptar el Plan Decenal. Se destaca que el escrito que se presenta a continuación se encuentra en proceso de validación y revisión por parte de la Gobernación de Cundinamarca y de la Asamblea Departamental para seguir el proceso hasta la aprobación. 
PROYEGTO DE ORDENANZA No

'POR LA GUAL SE ADOPTA EL PLAN DEGENAL DE GULTURA 2016 - 2026 PARA EL DEPARTAMENTO DE GUNDINAMARGA"

\section{La Asamblea Departamental de Cundinamarca:}

En uso de sus atribuciones constitucionales y legales, en especial las conferidas en el artículo 300 de la Constitución Política, en su numerales 1, 2 y 10 y, en el desarrollo de las leyes 1185 de 2008 y 397 de 1997, y los decretos 1589 de 1998 y 763 de 2009.

\section{ORDENA:}

ARTíCULO $1^{\circ}$.- Adoptar como líneas indicativas sobre políticas y estrategias para el desarrollo de la Cultura en el Departamento de Cundinamarca, las contenidas en el Plan Decenal de Cultura 2016 -2026, elaborado y validado por medio de instrumentos de participación ciudadana, con el fin de garantizar el mandato constitucional y legal de la Cultura, así como para buscar la eficiencia y eficacia en la acción pública, más allá de los períodos y planes gubernamentales con el objeto de:

Garantizar el derecho a la Cultura a toda la población con equidad y calidad, intentando siempre al aumento de la cobertura y la participación ciudadana a todo nivel.

Fortalecer la capacidad de gestión administrativa y de comunicación de cada una de las instancias del sector, y promover la articulación institucional tanto con los actores del sistema como con aquellos sectores con los que existe una relación inmanente (educación, deporte).

Fortalecer la capacidad instalada de atención de la demanda de la Cultura, intentando generar espacios e infraestructura adecuada y suficiente.

Crear un sistema de información sobre la cultura en el Departamento como insumo para la toma de decisiones y de evaluación del mismo Plan.

Incentivar el desarrollo y protección de las manifestaciones Culturales tanto materiales como inmateriales.

Privilegiar las acciones del desarrollo integral desde las dimensiones artística, creativa, del conocimiento, estética, lúdica y recreativa. 
Consolidar y afianzar la identidad cundinamarquesa a partir del reconocimiento de la diversidad étnica y cultural, la valoración del patrimonio histórico y las demás manifestaciones sociales.

Promover alianzas con el sector productivo para el fortalecimiento y desarrollo de proyectos culturales.

Crear herramientas de asignación y gestión de recursos e incentivos para la formación y ejecución de proyectos que contribuyen a la consolidación y desarrollo de la cultura cundinamarquesa.

ARTíCUlo 2.- El Plan Decenal de Cultura de Cundinamarca 2016-2026 establece los lineamientos y estrategias para la acción, a ser obligatoriamente tenidas en cuenta en el momento de adoptar el componente de Cultura en los planes de desarrollo departamental.

Sin perjuicio de la autonomía, los municipios también tendrán en cuenta el Plan Decenal en la elaboración y ejecución de sus planes de desarrollo municipal para garantizar identidad y coherencia regional.

De igual manera, sin detrimento de la autonomía, las demás instancias tanto privadas como públicas, que tengan relación con la Cultura en el Departamento de Cundinamarca, incorporarán en sus programas y proyectos los lineamientos y estrategias del Plan en aquello que les corresponda.

ARTíCulo $3^{\circ}$.- El Instituto Departamental de Cultura y Turismo de Cundinamarca y las instancias del nivel departamental y municipal diseñarán y adoptarán las siguientes estrategias indicativas para la ejecución, implementación, monitoreo, seguimiento y evaluación del Plan Decenal:

Socializar y divulgar el Plan Decenal, así como propender por la formación para la planeación en el orden municipal.

Acompañar y brindar asesoría técnica a las distintas instancias del sector en el Departamento.

Establecer mecanismos y estrategias que aseguren la financiación para la ejecución del Plan Decenal por medio de los programas y proyectos integrados. Así como el registro y ejecución de un proyecto que garantice de manera periódica el monitoreo, seguimiento y evaluación del Plan Decenal. 
ARTíCULO $4^{\circ}$.- El gobierno departamental y los gobiernos municipales llevarán a cabo acciones, dentro de sus correspondientes comunidades, tendientes a la divulgación, estudio y apropiación social del "Plan Decenal de Cultura de Cundinamarca 2016-2026” y garantizarán fuentes para la financiación del mismo mediante la creación de fondos, la inversión de los recursos del presupuesto de cada municipio destinados a la ejecución de las estrategias y lineamientos de este, así como los demás aportes provenientes de la Cooperación Internacional, de los aportes y donaciones del sector productivo y de terceros, al igual que apropiaciones de entidades públicas con destinación específica para el Plan que se incorporen al presupuesto del Departamento.

ARTíCULO 5․- La presente Ordenanza rige a partir de la fecha de publicación y deroga las normas que le sean contrarias.

COMUNÍQUESE, PUBLÍQUESE Y CÚMPLASE

Dada en Bogotá, D.C. 


\section{CONGLUSIONES}

H s manifiesto el interés y la voluntad del Estado

Ecolombiano por generar e implementar políticas públicas para la cultura. Desde el Ministerio de Cultura, se han planteado una serie de acciones institucionales y temáticas para asegurar el desarrollo de estas políticas. No obstante, es importante que el orden desagregado (los departamentos y los municipios) genere instrumentos de planeación que sean articulados y estén en consonancia con la política del Estado.

En atención a lo anterior, el Departamento de Cundinamarca, por medio del IDECUT, ha gestado la formulación del Plan Decenal; el cual se elaboró por medio de una metodología participativa, interpretando tanto los intereses como el conocimiento que tienen aquellos con el poder de tomar de decisiones y los actores que se ven relacionados con la cultura. Se obtuvo, por consiguiente, un Plan que refleja las principales necesidades para el desarrollo de la cultura en el Departamento y, a la vez, los objetivos estratégicos y metas para dar solución a las situaciones consideradas como problemáticas. Es de resaltar que tanto la identificación de problemas como el planteamiento de alternativas de solución pasaron por un proceso de validación y evaluación por parte de los actores relacionados.

Es importante aclarar que el análisis de los resultados de la investigación plantea que las principales problemáticas corresponden al fortalecimiento de la institucionalidad. Por ello, los objetivos estratégicos propuestos corresponden a temas relacionados con la continuidad de las políticas, la articulación entre actores, el mejoramiento de la gestión y 
de la comunicación. En una etapa posterior - es decir, en el siguiente Plan, y una vez solucionados los problemas identificados- la planeación podría corresponder a asuntos temáticos específicos.

Otro aspecto relevante del Plan Decenal de Cultura para el Departamento de Cundinamarca es el carácter multidimensional. Lo anterior, implica que el Plan se pensó para ser aplicado a todas las manifestaciones culturales del Departamento: artes plásticas, artesanía, bibliotecas, cinematografía, danza, eventos tradicionales, literatura, medios de comunicación, música, patrimonio y teatro. Además, el alcance está estructurado para las poblaciones étnicas y diversamente hábiles; dichos conjuntos poblacionales participaron activamente en el proceso de formulación del Plan.

El reto para las administraciones encargadas de la cultura en el Departamento de Cundinamarca en los próximos diez años es la ejecución e implementación de este Plan. Si bien se identificaron una serie de variables que dan viabilidad, es importante tenerlas en cuenta en el momento de la implementación del presente Plan, para intentar controlar o reducir la brecha entre lo planeado y la realidad de ejecución. En este sentido, es menester del ejecutor del Plan realizar el seguimiento a los planes de implementación y evaluación. Pues esto permitirá que se tomen los correctivos en el momento adecuado y, de ser necesario, reformular algunos aspectos, en tanto la política pública es dinámica. 


\section{REFERENCIAS}

Ajuntament de Barcelona. United Cities and Local Goverments. (2004). Agenda 21 de la cultura. Obtenido de http://www.agenda2lculture.net/index.php/docman/ agenda21/222-ag21es/file

Alcaldía Mayor de Bogotá. (2005). Políticas Culturales Distritales 2004-2016. Obtenido de http://www.culturarecreacionydeporte.gov.co/sites/default/files/politicas_ culturales_distritales_2004-2016.pdf

Alcaldía Mayor de Bogotá. (2011). Lineamientos de Política Cultural 2012-2014. Obtenido de http://www.culturarecreacionydeporte.gov.co/lineamientosde-politica-cultural

Alcaldía Mayor de Bogotá. (2015). Decreto 070 de 2015. Obtenido de http://www. alcaldiabogota.gov.co/sisjur/normas/Normal.jsp?i=60956

Alcaldía Mayor de Bogotá. (2015). Guía para la formulación, implementación y evaluación de Políticas Publicas Distrtales. Obtenido de http://www.alcaldiabogota.gov.co/sisjur/ adminverblobawa?tabla=T_NORMA_ARG

Álvarez, S. E., Dagnino, E., \& Escobar, A. (2001). Política cultural y cultura política. Bogotá: Tauros, Icanh.

An, C. (2011). Culture policy in Germany - the case of culture policy in Berlin -. The Journal of Korean Studies, 37, 59-88.

Buitrago, F., \& Duque, I. (2013). La economía naranja: una oportunidad infinita. Bogotá: Banco Interamericano de Desarrollo.

Carta Cultural Iberoamericana. (julio de 2006). IX Conferencia Iberoamericana de Cultura. Obtenido de http://www.oei.es/xicumbredec.htm

Choi, S.-J. (2012). A study on the cultural policy of Soviet Ukraine. 간행물명: 동유럽발칸학 - Estudio de los balcanes orientales., 335-354.

Coelho, T. (1997). Diccionario crítico de política cultural (292 ed.). São Paulo: Iluminuras.

Congreso de la República de Colombia. (1991). Constitución Política de Colombia.

Congreso de la República de Colombia. (22 de diciembre de 1993). Ley 98 de 1993. Por medio de la cual se dictan normas sobre democratización y fomento del libro. Obtenido de http://www.bibliotecanacional.gov.co/issn/files/Ley-98-de-1993.pdf 
Congreso de la República de Colombia. (7 de agosto de 1997). Ley 397 de 1997. Reglamentada parcialmente por los Decretos Nacionales 833 de 2002 , 763, 2941 de 2009, 1100 de 2014. Obtenido de http://www.alcaldiabogota.gov.co/sisjur/normas/ Normal.jsp?i=337

Congreso de la República de Colombia. (30 de julio de 2001). Ley 666 de 2001. Por medio de la cual se modifica el artículo 38 de la Ley 397 de 1997 y se dictan otras disposiciones. Obtenido de http://www.alcaldiabogota.gov.co/sisjur/normas/Normal.jsp?i=4158

Congreso de la República de Colombia. (2 de julio de 2003). Ley 814 de 2003. Por la cual se dictan normas para el fomento de la actividad cinematográfica en Colombia. Obtenido de http://www.alcaldiabogota.gov.co/sisjur/normas/Normal.jsp?i=8796

Congreso de la República de Colombia. (12 de marzo de 2008). Ley 1185 de 2008. Por la cual se modifica y adiciona la Ley 397 de 1997 -Ley General de Cultura-y se dictan otras disposiciones. Obtenido de http://www.alcaldiabogota.gov.co/sisjur/normas/ Normal.jsp? $\mathrm{i}=29324$

Congreso de la República de Colombia. (26 de diciembre de 2011). Ley 1493 de 2011. Por la cual se toman medidas para formalizar el sector del espectáculo público de las artes escénicas, se otorgan competencias de inspección, vigilancia y control sobre las sociedades de gestión colectiva y se dictan otras disposiciones. Obtenido de http://www. secretariasenado.gov.co/senado/basedoc/ley_1493_2011.html

Congreso de la República de Colombia. (9 de julio de 2012). Ley 1556 de 2012. Por la cual se fomenta el territorio nacional como escenario para el rodaje de obras cinematográficas. Obtenido de http://www.cancilleria.gov.co/sites/default/files/tramites_servicios/ visas/archivos/ley_1556_de_2012.pdf

Congreso de la República de Colombia. (30 de julio de 2013). Ley 1775 de 2013. Por medio de la cual se reglamentan los artículos 63, 70 y 72 de la Constitución Política de Colombia en lo relativo al patrimonio cultural sumergido. Obtenido de http://wsp. presidencia.gov.co/Normativa/Leyes/Documents/2013/LEY\%201675\%20 DEL $\% 2030 \% 20 D E \% 20 J U L I O \% 20 D E \% 202013$.pdf

Czerniewicz, L., \& Brown, C. (Agosto de 2009). • A study of the relationship between institutional policy, organisational culture and e-learning use in four South African universities. Computers $\&$ Education, 53(1), 121-131.

Departamento Nacional de Planeación. (10 de mayo de 2002). Documento CONPES 3162. Lineamientos para la sostenibilidad del Plan Nacional de Cultura 2001-2010 "Hacia una ciudadanía democrática cultural'. Obtenido de http://www.icbf.gov.co/cargues/ avance/docs/conpes_dnp_3162_2002.htm

Departamento Nacional de Planeación. (4 de noviembre de 2003). Documento CONPES 3255. Lineamientos de políica para la distrubución del 25\% de los recursos 
territoriales provenientes del incremento del 4\% del IVA a la telefonía movil. Obtenido de http://www.coldeportes.gov.co/index.php?idcategoria=2185

Departamento Nacional de Planeación. (20 de febrero de 2006). CONPES 3409. Lineamientos para el fortalecimiento del Plan Nacional de Música para la Convivencia. Obtenido de http://www.icbf.gov.co/cargues/avance/docs/conpes_ dnp_3409_2006.htm

Departamento Nacional de Planeación. (12 de marzo de 2007). CONPES 3462. Lineamientos para el fortalecimiento de la Cinematografía en Colombia. Obtenido de http://www.mincultura.gov.co/areas/cinematografia/Legislacion/Documents/ Conpes\%203462.pdf

Departamento Nacional de Planeación. (26 de abril de 2010). CONPES 3658. Lineamientos de Politica para la recuperación de los centros históricos en Colombia. Obtenido de http://www.mincit.gov.co/minturismo/descargar.php?id=20097

Departamento Nacional de Planeación. (21 de julio de 2010). CONPES 3659. Política Nacional para la promoción de las industrias culturales en Colombia.

Departamento Nacional de Planeación. (13 de febrero de 2014). CONPES 3803. Politica Nacional para la preservación del Paisaje Cultural Cafetero de Colombia. Obtenido de https:// colaboracion.dnp.gov.co/CDT/Conpes/Econ\%C3\%B3micos/3803.pdf

Departamento Nacional de Planeación. (2015). Planeación de la Cultura en Colombia. Obtenido de https://www.dnp.gov.co/programas/desarrollo-social/subdireccionde-educacion/Paginas/cultura.aspx

Dumoulin, L., \& Saurugger, S. (2010). Les policy transfer studies: analyse critique et perspectives. Presses de Sciences Po, Critique internationale, 3(48), 9-24.

Ferilli, G., Sacco , P., \& Noda, K. (2015). Políticas y revalorización de los activos culturales locales Cultura impulsado: Un cuento de dos ciudades, de Otaru y Yubari. Ciudad, Cultura y Sociedad.

García Canclini, N. (julio de 1997). Para un diccionario herético de estudios culturales. Revista Fractal(18), 11-27.

García Canclini, N. (2001). Por qué legislar sobre industrias culturales. Nueva Sociedad, 59-70.

García Ramírez, F., \& Campuzano, M. (2015). Políticas culturales en el extranjero. Revista Letras Libres. Obtenido de http://www.letraslibres.com/revista/convivio/ politicas-culturales-en-el-extranjero

Gautier, A. M. (2003). Entre los deseos y los derechos, un ensayo crítico sobre políticas culturales. Bogotá: Icanh. 
Gelio, A. (2009). Noches áticas. Madrid-España: Akal.

Gobernación de Bolívar. (2012). Plan de Desaarrollo del Departamento de Bolivar. Obtenido de http://www.observatoriodeldeporte.gov.co/docs/col/36/attach/ Plan_de_desarrollo_departamento_de_Bolivar_2012-2015.pdf

Gobernación del Valle. (2010). Valle del Cauca. Obtenido de http://www.valledelcauca. gov.co/

Gossaín, R. J. (2012). Plan de Desarrollo Departamento de Bolivar. Obtenido de http:// www.observatoriodeldeporte.gov.co/docs/col/36/attach/Plan_de_desarrollo_ departamento_de_Bolivar_2012-2015.pdf

Henry, I., \& Ko, L.-M. (2014). Handbook of Sport Policy. New York: Routledge.

Howlett, M., Ramesh, M., \& Perl, A. (2009). Studying Public Policy. Policy Cycles and Policy Subsystems. Oxford: Oxford University Press.

Instituto de Cultura y Patrimonio de Antioquia. (2012). Consulta virtual: política cultural para Antioquia. Obtenido de http://www.culturantioquia.gov.co/ciudadaniacultural/antioquia-diversas-voces/consulta-virtual-politica-cultural-paraantioquia.html

Ives, M., \& Jean Claude, T. (1992). Las políticas públicas. España: Ariel Ciencia Política.

Jaramillo, L., \& Zuleta, L. (2003). Impacto Económico del patrimonio del Centro Histórico de Bogotá D.C. Obtenido de Convenio Andrés Bello y Corporación de la Candelaria: http://www.sinic.gov.co/sinic/cuentasatelite/documentos/001a009.pdf

Kingdon, J. (1995). Agendas, alternatives and public policies. New York: Harper Collins.

Mark, C. (1969). A study of cultural policy in the United States. Paris: UNESCO.

Ministerio de Cultura. (2001). Plan Nacional de Cultura 2001-2010. Hacia una ciudadanía democrática cultural. Un plan colectivo desde y para un país cultural. Obtenido de Planes y programas: http://www.mincultura.gov.co/planes-y-programas/Planes/plan\%20 nacional $\% 20 \mathrm{de} \% 20$ cultura/Paginas/default.aspx

Ministerio de Cultura. (2008). Un Ministerio de Puertas Abiertas.

Ministerio de Cultura. (2011). Compendio de políticas culturales. Obtenido de https:// culturaparaeldesarrollo.files.wordpress.com/2011/06/mincultura-colombiacompendio-polc3adticas-culturales.pdf

Ministerio de Cultura. (2014). Documento de análisis situacional 2014.

Ministerio de Cultura. (s.f.). Politica Pública de Conservación del Patrimonio Cultural. Obtenido de SINIC: http://www.sinic.gov.co/sinic/cuentasatelite/documentos/ $027 \% 20 \mathrm{a}^{0} 020$ 038.pdf 
Moreno, Z. P. (2011). Políticas Culturales en Colombia. Obtenido de http://www. comunidadandina.org/public/libro_114.htm

Muller, P. (2002). Las políticas públicas. Bogotá: Universidad Externado de Colombia.

Municipio de Chocontá. (2015). Plan de Acción de la Secretaria de Cultura.. Obtenido de http://www.choconta-cundinamarca.gov.co/index.shtml?apc=v-xxl$\& x=3059476$

Municipio de Facatativá. (2015). Documento preliminar política pública y plan decenal de cultura municipio de Facatativá. Facatativá.

Municipio de Girardot. (2011). Plan de Desarrollo Girardot 2012-2015. Obtenido de http://candidatosconlaeducacion.esap.edu.co/wp-content/uploads/2015/07/ PLAN_DE_DESARROLLO_FINAL_-GIRARDOT_2012-2015.pdf

Navarro Alcalá-Zamora, P. (1985). Sociedades, pueblos y culturas. Barcelona: Salvat Pamplona.

Ordóñez-Matamoros, G. (2013). Manual de análisis y diseño de políticas públicas. Bogotá: Universidad Externado de Colombia.

Organización de Estados Iberoamericanos. (Noviembre de 2001). XI Cumbre Iberoamericana de Fefes de Estado y de Gobierno. Obtenido de Declaración de Lima: http://www.oei.es/xicumbredec.htm

Organización de Estados Iberoamericanos. (julio de 2006). IX Conferencia Iberoamericana de Cultura. Obtenido de Carta Cultural Iberoamericana: http:// www.oei.es/xicumbredec.htm

Retamoso, G. (2010). Historia de la Cultura en 20 lecciones. Bogotá: Universidad Sergio Arboleda.

Roth Deubel, A. N. (2009). Políticas Públicas. Formulación, implementación y evaluación. Bogotá: Ediciones Aurora.

Samper Pizano, E. (5 de agosto de 1998). Decreto 1589 de 1998. Por el cual se reglamenta el Sistema Nacional de Cultura. Obtenido de http://www.iadb.org/research/ legislacionindigena/leyn/docs/CO-Decreto-1589-98-Reglamenta-SistemaNacional-Gultura-.doc

Sanabria, A. A. (2000). Ley General de Cultura (Ley 397 de 1997). Bogotá: Ministerio de Cultura, Imprenta Nacional de Colombia, artículo 57.

Smith, K., \& Larimer, C. (2009). The Public Policy Theory Primer Boulder. Colorado: Westview Press.

UNESCO. (1982). Conferencia mundial sobre las políticas culturales. UNESCO. 
UNESCO.(6 de agosto de 1982).Declaración de México sobrelaspolíticasculturales. Obtenido de http://portal.unesco.org/culture/es/files/35197/11919413801mexico_sp.pdf/ mexico_sp.pdf

UNESGO. (1996).Nuestra diversidad creativa. Obtenido de Comisión mundial de cultura y desarrollo: http://unesdoc.unesco.org/images/0010/001055/105586sb.pdf

UNESCO. (1998). Conferencia intergubernamental sobre politicas culturales al servicio del desarrollo. ObtenidodeProyectodeplandeacción sobrepolíticasculturalesalservicio del desarrollo: http://unesdoc.unesco.org/images/0011/001163/116393So.pdf

UNESGO. (2002). Declaración Universal sobre la diversidad cultural. Obtenido de http:// unesdoc.unesco.org/images/0012/001271/127162s.pdf

UNESCO. (2010). Derechos culturales. Obtenido de Documentos básicos de Naciones Unidas: http://www.unescoetxea.org/dokumentuak/dchoscult_docbasicONU.pdf

Uribe Vélez, A. (25 de junio de 2003). Decreto 1746 de 2003. Por el cual se determinan los objetivos y estructura orgánica del Ministerio de Cultura y se dictan otras disposiciones. Obtenido de http://www.secretariasenado.gov.co/senado/basedoc/ decreto_1746_2003.html

Uribe Vélez, A. (4 de abril de 2003). Decreto 826 de 2003. Por el cual se modifica el Decreto 267 de 2002. Obtenido de http://www.alcaldiabogota.gov.co/sisjur/normas/ Normal.jsp? $\mathrm{i}=7840$

Uribe Vélez, A. (4 de febrero de 2004). Decreto 352 de 2004, reglamentaria de la Ley 814 de 2003. Por el cual se reglamenta los artículos $7^{\circ}, 9^{\circ}, 12^{\circ}, 14^{\circ}$ y $16^{\circ}$ de la Ley 814 de 2003 (fomento de la actividad cinematográfica). Obtenido de http://www.alcaldiabogota. gov.co/sisjur/normas/Normal.jsp?i=11691

Uribe Vélez, A. (23 de abril de 2008). Decreto 1313 de 2008. Por el cual se reglamenta el artículo $7^{\circ}$ de la Ley 397 de 1997, modificado por el artículo $4^{\circ}$ de la Ley 1185 de 2008, relativo al Consejo Nacional de Patrimonio Cultural. Obtenido de http://www. alcaldiabogota.gov.co/sisjur/normas/Normal.jsp?i=30005

Uribe Vélez, A. (10 de marzo de 2009). Decreto 763 de 2009. Por medio del cual se reglamentan parcialmente las leyes 814 de 2003 y 397 de 1997, modificada por medio de la Ley 1185 de 2008, en lo correspondiente al Patrimonio Cultural de la Nación de naturaleza material. Obtenido de http://www.alcaldiabogota.gov.co/sisjur/normas/Normal. jsp?i=35447

Valencia Cossio, F. (6 de agosto de 2009). Decreto 2941 de 2009. Por el cual se reglamenta parcialmente la Ley 397 de 1997, modificada por la Ley 1185 de 2008, en lo correspondiente al Patrimonio Cultural de la Nación de naturaleza inmaterial. Obtenido de http://www. alcaldiabogota.gov.co/sisjur/normas/Normal.jsp?i=37082 
Vargas V, A. (1999). Notas sobre el Estado y las políticas públicas. Bogotá: Almudena Editores.

Velásquez Gavilanes, R. (2009). Hacia una nueva definición del concepto "política pública”. Desafios(20), 149-187.

Zhang, Y. (2015). Culture Policy Regimes in China. International Encyclopedia of the Social \& Behavioral Sciences, 596-601. 



\section{AUTORES}

Miguel Geballos Arévalo: Decano de la Escuela de Política de la Universidad Sergio Arboleda de Bogotá (primer periodo: 2009-2010; segundo periodo: julio de 2013 hasta hoy). Viceministro de Justicia de Colombia. Director del Instituto de Derechos Humanos y Derecho Internacional Humanitario de la Universidad Sergio Arboleda. Es abogado de la Universidad Javeriana, con maestría en Filosofía Política; Summa Cum Laude de la Universidad Gregoriana de Roma; candidato a doctorado en Derecho de la Universidad Sergio Arboleda. Fue director jurídico de la Universidad Javeriana; fundador y director del Instituto de Derechos Humanos y Relaciones Internacionales de la Universidad Javeriana; secretario ejecutivo de la Comisión de Conciliación Nacional, entidad facilitadora de Paz en Colombia. Director general del Programa Colombia, de la Universidad de Georgetown en Washington D. C., cargo en el que promovió las políticas de seguridad ciudadana en más de 14 ciudades colombianas.

Antonio Quiñones Valero: Se desempeña como Director de Investigación de la Escuela de Política y Relaciones Internacionales de la Universidad Sergio Arboleda, donde lidera, junto con el Dr. Rodrigo Losada Lora, el Grupo de Investigación en Análisis Político registrado y reconocido por Colciencias en categoría A. Actualmente es candidato a Doctor en Estudios Políticos en la Universidad Externado de Colombia. Es Magister en Estudios Políticos de la Pontificia Universidad Javeriana, Especialista en Estudios Políticos de la Universidad Sergio Arboleda y es Economista de la Universidad Autónoma de Colombia. 
Su área de interés y de su experticia es la de Políticas Públicas, sobre la cual ha publicado varios libros y artículos resultados de investigación.

Santiago José Castro Agudelo: Vicedecano de la Escuela de Política y Relaciones Internacionales desde 2013. Fue nombrado como uno de los "30 menores de 30" de la revista Semana. Politólogo de la Universidad de los Andes con énfasis en política comparada y política colombiana, Historiador de la Universidad de los Andes y Magíster en Estudios Políticos en la Universidad Javeriana. Fue Secretario Técnico del Directorio Nacional Conservador, encargado de la Organización Nuevas Generaciones del Partido Conservador a nivel nacional, al igual que profesor investigador de medio tiempo dictando los cursos "Historia de Colombia" y "Partidos Políticos en Colombia" en la Facultad de Derecho de la Universidad La Gran Colombia. Coordinó el Programa de Seguimiento y Acompañamiento Legislativo (PSAL) en el marco del convenio de cooperación existente entre el Partido Conservador Colombiano, la Corporación Pensamiento siglo XXI, la Academia del Pensamiento Conservador y Humanista, el Instituto Republicano Internacional y la Fundación Konrad Adenauer de Alemania. Fue catedrático de la Universidad Sergio Arboleda dictando el curso de "Introducción a la Ciencia política" y en la Universidad EAN dictando los cursos "International Culture" y "Constitución, Ética y Responsabilidad Social Empresarial".

Viviana Manrique Zuluaga: Abogada, internacionalista y profesional en Filosofía de la Universidad del Rosario, especialista en Altos Estudios Europeos con énfasis en Cooperación y Negociación con Europa de la Universidad del Rosario, especialista en Estado, Gobierno y Políticas Públicas, actualmente es Magister en Estudios interdisciplinarios de Desarrollo de la Universidad de los Andes. Se ha desempeñado como asesora del Alto Consejero Presidencial para la Competitividad y la Productividad, representante de Colombia ante el Plan Puebla-Panamá, en calidad de suplente del comisionado presidencial principal, entre otros destacados cargos. Ha sido catedrática de la Universidad del Rosario e investigadora en temas de política exterior colombiana de la misma universidad. Se desempeñó como Viceministra del Interior. Ha sido autora de los libros titulados: "Nueva Reforma Política y Proceso Electoral del año 2010: aspectos básicos para votar en las elecciones legislativas de 2010" y "La tenue línea de la tranquilidad: estudio comparado sobre seguridad ciudadana y política". 
Rodrigo González Quintero: Docente, investigador y Decano Asociado para Asuntos Internacionales de la Escuela Mayor de Derecho de la Universidad Sergio Arboleda, Bogotá-Colombia. Doctor en Derecho (J.S.D.) y Magíster en Derecho (LL.M.) por Washington University in St. Louis; Magíster en Historia (M.A.) de Illinois State University; Abogado Universidad de Navarra. Se ha desempeñado como docente de la Universidad de la Sabana, autor de los libros: "John Locke: los fundamentos del liberalismo" e "Introducción a Feremy Bentham: los fundamentos del estado colombiano". Ha participado en los proyectos de investigación denominados: "Derecho constitucional comparado" y "Comparative Law"; investigaciones que denotan un análisis comparado de instituciones y actores constitucionales en el mundo y estudios comparados de procesos constituyentes en Asia, Europa y América Latina. Ha sido autor de numerosos artículos científicos como "Judicial review in the Republic of Korea: an introduction", "Procesos constituyentes y cortes constitucionales: una perspectiva comparada", "Poder y constitución: una aproximación al constitucionalismo de los primeros tiempos republicanos en Norteamérica y en la Nueva Granada". 
